\title{
Recent Advances in Glycerol Catalytic Valorization: A Review
}

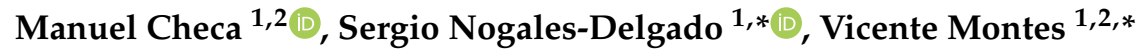 \\ and José María Encinar ${ }^{1}$ (D) \\ 1 Department of Chemical Engineering and Physical-Chemistry, University of Extremadura, \\ 06006 Badajoz, Spain; mcheca@unex.es (M.C.); jencinar@unex.es (J.M.E.) \\ 2 University Institute of Water, Climate Change and Sustainability (IACYS), University of Extremadura, \\ 06006 Badajoz, Spain \\ * Correspondence: senogalesd@unex.es (S.N.-D.); vmontes@unex.es (V.M.)
}

Received: 30 September 2020; Accepted: 24 October 2020; Published: 3 November 2020

check for updates

\begin{abstract}
Once a biorefinery is ready to operate, the main processed materials need to be completely evaluated in terms of many different factors, including disposal regulations, technological limitations of installation, the market, and other societal considerations. In biorefinery, glycerol is the main by-product, representing around $10 \%$ of biodiesel production. In the last few decades, the large-scale production of biodiesel and glycerol has promoted research on a wide range of strategies in an attempt to valorize this by-product, with its transformation into added value chemicals being the strategy that exhibits the most promising route. Among them, C3 compounds obtained from routes such as hydrogenation, oxidation, esterification, etc. represent an alternative to petroleum-based routes for chemicals such as acrolein, propanediols, or carboxylic acids of interest for the polymer industry. Another widely studied and developed strategy includes processes such as reforming or pyrolysis for energy, clean fuels, and materials such as activated carbon. This review covers recent advances in catalysts used in the most promising strategies considering both chemicals and energy or fuel obtention. Due to the large variety in biorefinery industries, several potential emergent valorization routes are briefly summarized.
\end{abstract}

Keywords: glycerine; glycerol; active carbon; catalytic valorization; reforming; dehydration; hydrogenolysis; oxidation

\section{Introduction}

Glycerol (propane-1,2,3-triol) is an organic compound with hydrophilic and hydrophobic properties [1,2]. It is a by-product generated in diverse processes, such as fermentation with yeasts, bacteria, or algae; propylene synthesis (for instance, propylene chlorination); oil hydrolysis (soap production); and biodiesel production by transesterification (through homogeneous or heterogeneous catalysis) [3-5]. In the latter case, glycerol generation represents $10 \%$ of biodiesel production, which means a production of $9 \mathrm{~kg}$ of biodiesel and $1 \mathrm{~kg}$ of glycerol per $10 \mathrm{~kg}$ of fatty matter consumption [2]. In this way, glycerol is a large produced kg by-product, with plenty of uses, depending on its degree or purity; for instance, it is used for pharmaceutical, cosmetic, and energy purposes. After World War II, biodiesel production (and consequently glycerol generation) considerably increased and, with the environmental concerns in the last few decades, the scientific community has focused their efforts on environmental protection and the development of sustainable processes with respect to the environment [6]. In this context, biorefineries have emerged as an important pillar for achieving both sustainable energy and chemicals [7]. With a rising production since the 2000's and glycerol as the main by-product, this industry quickly became the main glycerol producer (in this 
case, crude glycerol, which is glycerol mixed with alcohol, catalysts, fatty acids, etc.), oversaturating markets and plummeting prices (Figure 2). According to Figure 2, stabilization and a possible decline in biodiesel production are expected in the next decade, as stated by the Organisation for Economic Co-operation and Development (OECD). This trend would be a consequence of second and third generation biofuel development and industrial application, with products obtained from non-edible sources [8-13]. In any case, future biodiesel production depends on several factors, such as raw material availability, internal policies, markets, etc., in some cases leading to a local production rise against the international trend, becoming a stable crude glycerol source [13].

Biorefinery produces crude glycerol, that is, glycerol mixed with alcohol, catalysts, fatty acids, etc. As a consequence, biodiesel production becomes less efficient from an economic point of view $[1,14]$. The properties of this mixture vary from pure glycerol, and in some cases, become a challenge for waste management in biodiesel production. The glycerol content and its high valorization potential justify its selection as a platform molecule $[2,15,16]$. As a highly functionalized molecule, glycerol can be incorporated as a raw material into processes to obtain molecules of industrial interest, providing sustainable route alternatives to the traditional ones, based on petroleum [16-21]. Therefore, many processes (as will be explained in the following sections) can make glycerol a valuable by-product, by obtaining a purer product (using it for energy purposes) or by chemical reactions (to obtain new compounds). Research on glycerol transformation is very intensive, as evidenced by the large number of publications in the field (Figure 1), including 2835 publications from 2018 to 2020, using the Scopus database and "glycerol or glycerine" and "catalysis" as search words, and 15 reviews since 2018 [22-24] for special issues (for instance, New Glycerol Upgrading Processes, in the Catalyst journal [25]), books [26,27], book chapters [28], local density theories [29], and even large European projects like "Production of cyclic carbonates from $\mathrm{CO}_{2}$ using renewable feedstocks" [30] and "Glycerol Biorefinery Approach for the Production of High Quality Products of Industrial Value" [31].

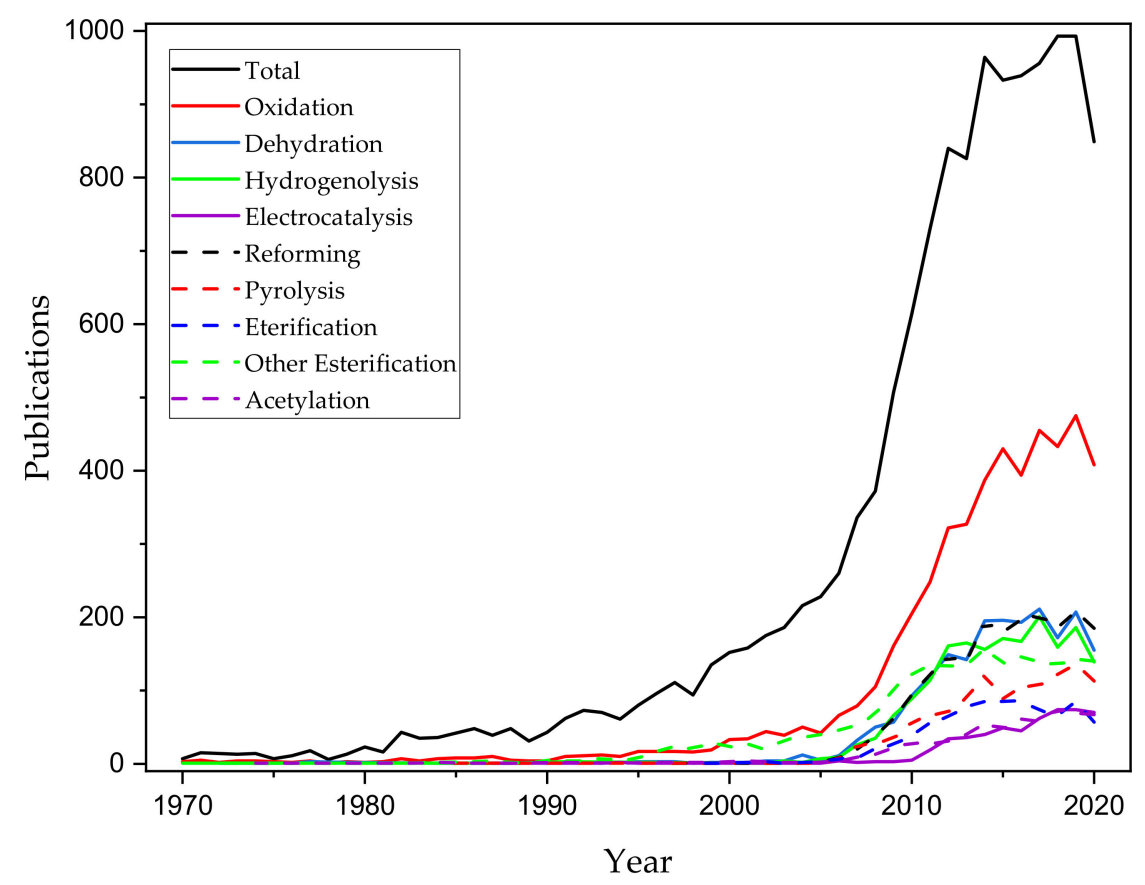

Figure 1. Evolution of the annual number of publications on the catalytic valorization of glycerol per process. Source: Scopus ${ }^{\circledR}$ (23rd September 2020). 


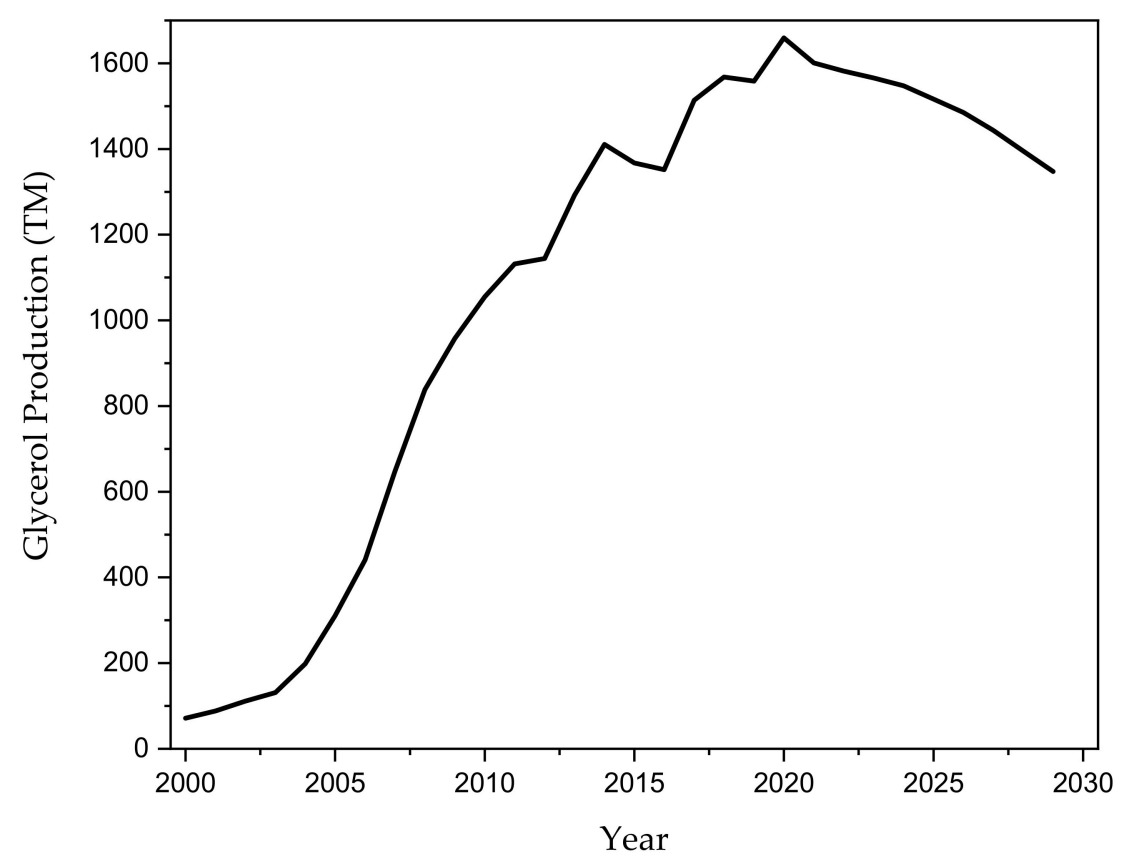

Figure 2. Glycerol production in the biodiesel industry: Trends and future estimations. Adapted from the OECD-FAO 2020/2029 database [32].

In this scientific literature (Figure 1), many routes or technologies have been described and developed to valorize glycerol, with the most common being thermochemical conversion, oxidation, hydrogenolysis, esterification, biological conversion, aqueous phase reforming, bioconversion, electro-conversion, etc. Some of these technologies overlap, e.g., thermochemical conversion is a very widely defined term and technically, it can englobe some other approaches, such as hydrogenolysis and oxidation. In several published scientific works, the role of catalysts is vital, in order to make these processes as efficient as possible. Whereas biodiesel production, in general, has clear chemical routes, with well-defined catalysts to be used in the process, in the case of glycerol, whose chemical routes and uses are so versatile (which implies, for instance, the use of multiple reactors or facilities), there is a vast field of knowledge which is usually difficult to cover [33]. A basic analysis of a glycerol molecule indicates that valorization routes imply the activation and reactivity of $\mathrm{C}-\mathrm{C}, \mathrm{C}-\mathrm{O}, \mathrm{C}-\mathrm{H}$, and/or $\mathrm{O}-\mathrm{H}$ bonds, depending on the nature of the desired product. The reactivity of the bonds involved determines the catalyst properties and the processing conditions to be used. This means that, for $\mathrm{C}-\mathrm{C}$ and $\mathrm{C}-\mathrm{O}$ cleavage, bifunctional catalysts with metal and acid/basic sites are suitable for the reaction $[34,35]$ and, among them, catalysts based in a metallic complex or $\mathrm{Rh}, \mathrm{Pd}$, and $\mathrm{Pt}$ nanoparticles over acid supports as zeolites or activated carbon are the most common ones. For $\mathrm{C}-\mathrm{H}$ or $\mathrm{O}-\mathrm{H}$, it seems that the metallic active center is the most important function [36,37], with noble metals such as $\mathrm{Pt}$, $\mathrm{Ru}$, and $\mathrm{Pd}$ being the most effective ones. During the last decade, alternatives to noble metals have been the target of many scientific publications, mainly using transition metals such as $\mathrm{Cu}, \mathrm{Ni}$, and $\mathrm{Co}$.

Most of the published reviews focus on one specific strategy, process, or specific reaction, whilst the others summarize the most common strategies for valorizing glycerol. In this review, we summarize the latest advances and trends for heterogeneous inorganic catalysts for some of the most common strategies, such as reforming, hydrogenolysis, oxidation, glycerol carbonate production, acetalization, and the photoconversion of glycerol. In order to cover a gap in the literature, this review briefly summarizes several emergent strategies recently reported or with not many publications, such as activated carbon production, crude glycerol direct usages, fuel additives, sacrificed molecules, templates for catalyst synthesis, polymers, $\mathrm{CO}_{2}$ capture, and the direct use of glycerol. 


\section{Treatment or Management of Crude Glycerol}

As mentioned in the introduction section, glycerol valorization is vital to making biodiesel production a more competitive and sustainable alternative for petroleum-based fuels. Considering this, there are four main options for making this process cost effective or environmentally friendly (Figure 3). As can be seen in Figure 3, there are four main choices once crude glycerol is produced in transesterification:

- Direct use: The main advantage of the direct use of crude glycerol is the avoidance of further and more expensive steps for glycerol management. Depending on the global composition (methanol, water, soap, or organic matter content) and the purity of crude glycerol, different direct processes can be suitable, such as anaerobic digestion, animal feed, thermo-chemical conversion, etc. Nowadays, the direct combustion of crude glycerol is not advisable, due to its low heating value (and therefore its low energy efficiency) and the unsustainable nature of this process, implying the production of toxic products, such as acrolein [1]. However, in practice, there are a few alternatives that can be used instead of low-purity glycerol [38]. That is the reason why the rest of the options are more popular in research. Nevertheless, new trends are currently being considered for the direct use of crude or residual glycerol, such as its use as an additive to produce biohydrogen by the anaerobic biodigestion of cassava wastewater [39];

- Preventing its production: In this case, other derivatives of glycerol are produced during transesterification by different means, resulting in interesting compounds, such as glycerol triacetate (Glyperol), glycerol carbonate (DMC-Biod), and monoglyceride (Ecodiesel), which contribute to a better atom yield during the transesterification of fatty acids [40,41];

- Purification: As abovementioned, crude glycerol has low prices, with its purification being expensive for small companies. This fact can explain the existence of the two previous options mentioned, and the research related to glycerol purification to develop a cheaper and more competitive process. Therefore, the alternative is the use of cheap or simple purification steps, in order to obtain high-quality glycerol as a starting point for the production of plenty of products (up to 1500) for multiple purposes [1]. Depending on the kind of catalyst used during the transesterification to obtain fatty acid methyl esters, the purification process can vary. The use of homogeneous catalysts (which are commonly used in industry) requires the separation of glycerol through a settler unit, the removal of surplus/excess catalysts with mineral acids, etc. On the other hand, the use of heterogeneous catalysts (which has some advantages, but usually few cycles offer acceptable yields) requires a double separation process, without catalyst neutralization $[3,33]$. Figure 4 presents a brief schematic representation of the main separation stages and the glycerol purity corresponding to the use of homogeneous catalysts, following previous separation through decanting or centrifugation from biodiesel. It should be noted that further refining steps can imply high energy costs, especially in the case of vacuum distillation. Other alternatives are the use of cyclic distillation columns or dividing wall distillation. If ion exchange is used, the removal of fatty acids, inorganic salts, and free ions at room temperature is possible and therefore low energy consumption is possible. Carbon absorption is required to remove small molecules (like lauric and myristic acids) and decolorization. Finally, for a high level of purification or pure glycerol, the mentioned techniques are simultaneously used-commonly known as combined steps-alternatively with membrane distillation [1]. Pure glycerol has a wider range of potential use than crude glycerol, due to its low toxicity, biodegradability, low vapor pressure, and high boiling point. For instance, it can be used in pharmaceutical, cosmetic, explosive, solvent, and food industries, among others [33,38]. Moreover, pure glycerol is normally used as starting material for further catalytic valorization, as it minimizes secondary reactions given or catalyzed by other compounds contained in crude glycerol. It should be underlined that the crude glycerol composition can vary due to the employment of different kinds of catalysts, their concentration, the alcohol/oil ratio, raw materials (especially vegetable oils, whose fatty acid profile considerably 
varies), and the yield of the transesterification reaction (and the subsequent crude glycerol purity). The wide range in composition may require some adjustments in the separation process (Figure 4), in order to be adequate for each crude glycerol obtained [38]. Alternatively, it should be noted that the separation process included in Figure 4 might require extra steps or variation, according to the crude glycerol obtained in each process. For instance, vegetable oils, whose fatty acid profile considerably varies, depending on the raw material, lead to a wide range of transesterification yields and thus subsequent crude glycerol purities [38];

- Chemical transformation: Both in the case of crude or pure glycerol (especially for the latter), multiple chemical routes have been investigated to produce more valuable products. Among them, the most common or described chemical routes should be pointed out, such as glycerol carboxylation, hydrogenolysis, oxidation, acetylation, and reforming, among others, which will be thoroughly explained in the following sections $[1,29]$.

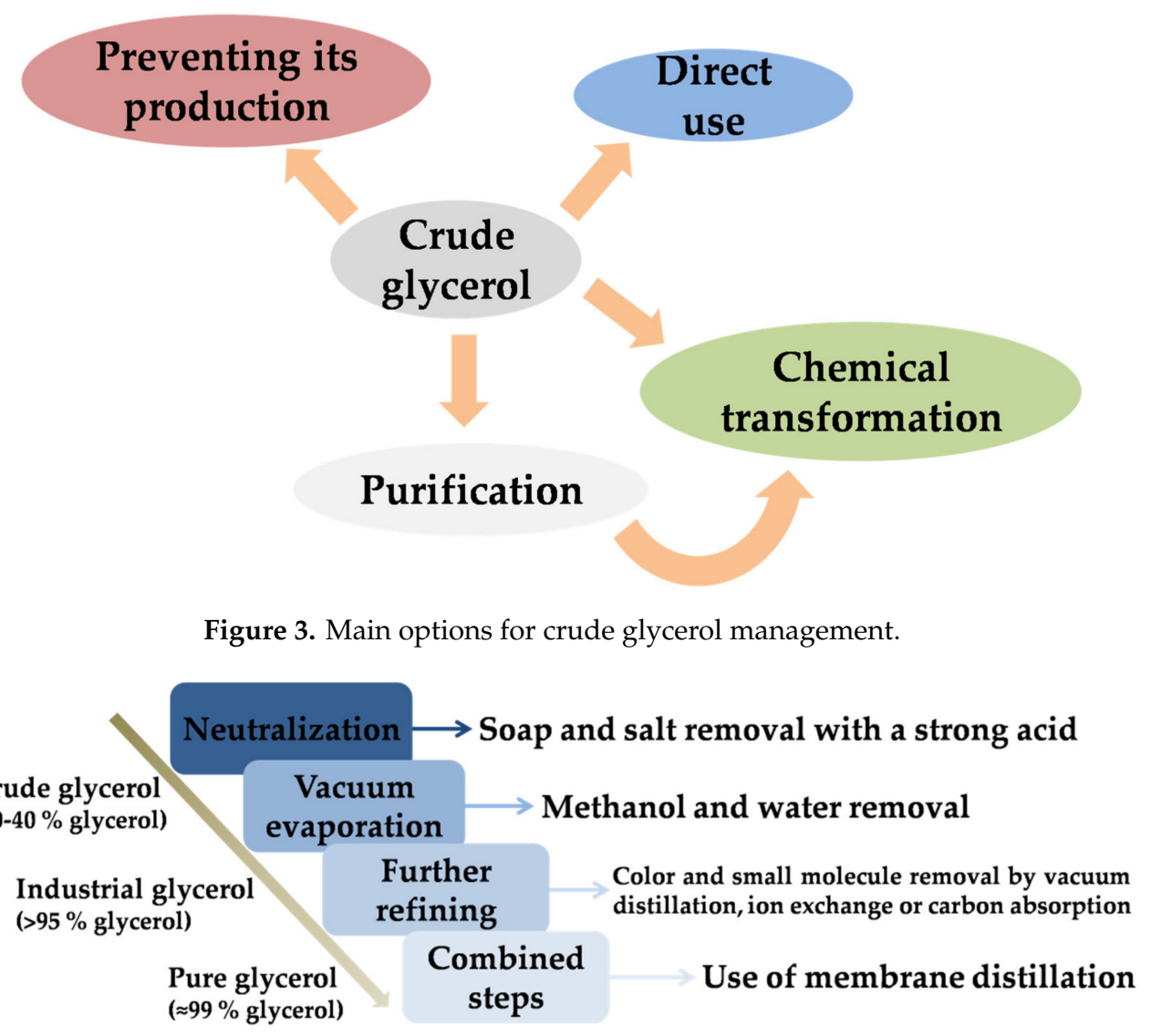

Figure 4. Purification stages from crude to pure glycerol.

It is important to note that there are studies focused on the sustainability of biodiesel production. For instance, in terms of the purification stage, new trends are being considered to make this process more sustainable, such as the use of activated carbon from biomass. Habaki et al. applied activated carbon from jatropha shells in the purification of glycerol. Their results showed the effective removal of methanol and monoolein from pre-treated glycerol [42].

\section{Energy Use of Glycerol}

The generation of energy from glycerol can be carried out directly or indirectly, by producing compounds that can act as an alternative energy source, such as hydrogen. There are specific ways to obtain energy from glycerol, such as direct combustion or pyrolysis (especially for crude 
glycerol), or reforming to produce $\mathrm{H}_{2}$, among others. In the following subsections, these processes are briefly explained.

\subsection{Combustion}

The use of crude glycerol to obtain thermal and electrical energy by direct combustion has been an economic and feasible choice for improving the economics of biodiesel production, limiting the use of petroleum resources for chemical production and not energy [43]. Normally, this is a process that does not require the addition of catalysts. However, it is not a suitable way of valorizing this by-product, as it has a low heating value (of around $18 \mathrm{MJ} / \mathrm{kg}$ ) and therefore, the yield of the process is low. Its viscosity and auto-ignition temperature are high and the presence of impurities can influence combustion, making it ineffective [43-45]. Moreover, this process is not environmentally friendly, as some contaminant emissions such as acrolein can be released into the environment and the production of $\mathrm{CO}_{2}$ increases the process's carbon footprint $[20,45,46]$. Nonetheless, this kind of pollutant can be removed through the oxy-combustion of glycerol [45]. This is the reason why other more sustainable chemical routes with better yields are preferred, where catalysts can play an important role. Nevertheless, some research has been carried out, including that on the combustion of glycerol. For instance, it was used to impregnate coal, in order to increase the heating value (up to 1.5 times), improving the combustion efficiency of the process, which can be used in coal-fired power plants, without any modification [47]. In addition, glycerol was used in fluidized bed feed with alumina sand for combustion [44,48,49] and combined with acetals [19].

\subsection{Pyrolysis}

Concerning the pyrolysis of glycerol, Figure 5 shows the main uses of this technique when applied to glycerol.

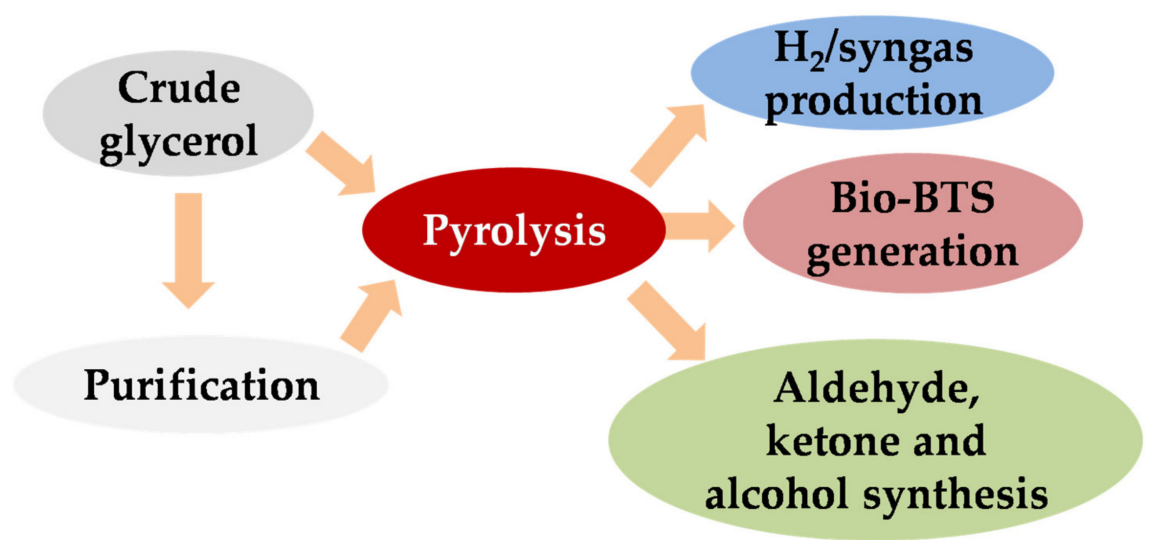

Figure 5. Main catalytic processes (and products obtained) for glycerol pyrolysis.

Firstly, this by-product can be an important hydrogen source in fixed beds, pyro-reforming plants, or furnaces, among others. Due to the low high heating value of glycerol (as was explained in the previous section), the pyrolytic production of syngas can be used as a fuel for combined heat and power generation, or in hydrogen fuel cells as a transportation method, in order to generate a better and cleaner fuel $[50,51]$. However, the yield in hydrogen is usually lower than in the case of glycerol reforming [50], which makes the use of heterogeneous catalysts necessary (such as those obtained from bituminous carbon or coconut shell), in order to compete with these processes. Another interesting approach is glycerol conversion through pyrolysis to obtain bio-based low molecular weight aromatics, such as bio-based benzene, toluene, and xylene (bio-BTX), which are intermediates for the synthesis of multiple polymers [52]. The application of metal-based catalysts is required for these processes (such as $\mathrm{Ni}, \mathrm{La}$, and $\mathrm{Nb}$ ), which are widely studied in the literature [3]. Nevertheless, other more recent ways 
to carry out pyrolysis can admit other kinds of catalysts, such as in the case of the microwave-assisted pyrolysis of glycerol over carbonaceous catalysts, where there is a strong influence of the operating conditions on the catalytic effect of the activated carbon [3]. Finally, the pyrolysis of glycerol can be used to convert it into higher added value products, such as aldehydes, ketones, and alcohols. Therefore, the main products of glycerol pyrolysis are organic liquids, gases, and char. In order to promote the organic liquid yield (rich in products such as acetals, ketals, glycerol esters, and acrylic acids, among others), fast pyrolysis can represent an alternative (see Table 1 , references $[53,54])$. Table 1 shows some specific catalysts that have recently been used in glycerol pyrolysis for different purposes, including the main details of each work.

Table 1. Catalysts recently used in glycerol pyrolysis.

\begin{tabular}{|c|c|c|c|}
\hline Metal & Support & Observations & Reference \\
\hline $\mathrm{Ce}-\mathrm{Ni}$ & $\alpha \mathrm{Al}_{2} \mathrm{O}_{3}$ & $\begin{array}{c}\mathrm{H}_{2}, \mathrm{CO}, \mathrm{CO}_{2} \text {, and } \mathrm{CH}_{4} \text { production with } \mathrm{H}_{2}: \mathrm{CO} \text { ratios } \\
\text { below } 2 \text { (suitable for Fischer-Tropsch synthesis), } \\
\text { obtained from primary glycerol decomposition }\end{array}$ & [55] \\
\hline $\mathrm{La}-\mathrm{Ni}$ & $\alpha \mathrm{Al}_{2} \mathrm{O}_{3}$ & $\begin{array}{l}\text { High catalytic activity on glycerol decomposition, due to } \\
\text { its high acidity, to produce } \mathrm{H}_{2}, \mathrm{CO}, \mathrm{CO}_{2} \text {, and } \mathrm{CH}_{4}\end{array}$ & [56] \\
\hline ZSM-5 & Bentonite & $\begin{array}{c}\text { Experiments in a bench scale unit to produce bio-BTX, } \\
\text { with coke formation on the catalyst as the main cause } \\
\text { of deactivation }\end{array}$ & [52] \\
\hline Ni Schiff base complex & SBA-15 silica & $\begin{array}{c}\mathrm{CO}_{2} \text {, aldehyde, ketone, and alcohol production through } \\
\text { fast pyrolysis. There were reductions in the } \\
\text { decomposition temperature of glycerol }\end{array}$ & [53] \\
\hline $\mathrm{Nb}_{2} \mathrm{O}_{5}$ & Vermiculite & $\begin{array}{c}\text { Used in flash pyrolysis to mainly produce organic acids, } \\
\text { esters, and aldehydes }\end{array}$ & [54] \\
\hline
\end{tabular}

\subsection{Glycerol Reforming}

The aim of glycerol reforming is to produce valuable products that are mainly used as alternative energy sources, such as hydrogen and syngas $\left(\mathrm{CO}+\mathrm{H}_{2}\right)$. Although biodiesel plants can use crude glycerol for energy generation by a direct burning process, it is not suitable due to the high viscosity and ignition point of glycerol, as well as the generation of several toxic compounds (such as acrolein). Consequently, reforming can be a good choice, especially since this kind of process can be easily adapted to existing industrial facilities [20]. The reforming process can be done on crude glycerol directly, which is an interesting alternative for the management of glycerol, as the purification of crude glycerol can be expensive and it cannot be directly used for other purposes due to its impurities (fatty acid methyl esters, water, rest of the catalysts, etc.). There are several ways to use glycerol for this purpose that have been widely studied in the literature, such as the following: Supercritical water reforming; partial oxidation; steam reforming; aqueous phase reforming; and a dry reforming reaction. In the following subsections, the three latter approaches will be covered. Therefore, many valuable products are usually obtained, depending on the process selected, such as 1,3-propanediol, propylene glycol, glyceric acids, polyols, and branch polyesters, among others. The wide range of possibilities observed has been derived from several current studies on glycerol reforming, dealing with the conversion of feedstocks, selectivity of the product, and the catalytic activity and its stability. All of these factors are influenced by the catalyst-support design. In general, noble metal catalysts are used, such as $\mathrm{Pd}, \mathrm{Ru}, \mathrm{Ir}$, $\mathrm{Rh}$, and $\mathrm{Pt}$, which show a good performance due to their high catalytic activity. On 00the other hand, there are other catalysts, such as $\mathrm{Ni}, \mathrm{Co}$, and $\mathrm{Cu}$, which are cheaper and easily available, displaying a desirable catalytic activity for promoting hydrogen production. However, their stability is not suitable, as they are usually deactivated by the coking effect. Consequently, the combined use of metals as catalysts to produce bimetallic catalysts, as well as the suitable selection of a support (depending on its porosity, redox properties, and thermal stability, among others), are important for obtaining a highly active and stable catalyst. Alumina is the preferred and most common support employed for this purpose, due to its high specific surface and thermal stability, although it tends to deactivate due to 
carbon deposition [20]. In the following subsections, different kinds of glycerol reforming are briefly explained, pointing out the particularities of catalyst implementation.

\subsubsection{Steam Reforming (SR)}

$\mathrm{H}_{2}$ and syngas are potential alternative molecules obtained from biomass within the energy strategy of valorization, and are effective and clean energy carriers with an excellent storage capacity [46,57]. Therefore, they represent an interesting starting point for producing methanol, short-chain alcohol, detergents, ammonia, and synthetic hydrocarbon fuels for turbines or engines, among others. Additionally, $\mathrm{H}_{2}$ can be used in the food industry (hydrogenation) or refineries (hydrocracking). On the other hand, syngas can be used in Fischer-Tropsch synthesis [20]. The main advantages of SR are its low cost and great development (starting in 1930), which explains the possibility of implementing it without significant modifications in industries. However, the main disadvantage of SR is the generation of $\mathrm{CO}_{2}$ (up to $25 \%$, depending on the conditions), which is a greenhouse effect gas [56].

The overall steam reforming reaction is presented in the following (Equation (1)):

$$
\mathrm{C}_{3} \mathrm{H}_{8} \mathrm{O}_{3}+\mathrm{xH}_{2} \mathrm{O}+\mathrm{yO}_{2} \rightarrow \mathrm{aH}_{2}+\mathrm{bCO}_{2}+\mathrm{cCO}+\mathrm{dH}_{2} \mathrm{O}+\mathrm{eCH}_{4}
$$

The general reaction of steam reforming (Equation (1)) is endothermic, being favored at temperatures of around $800{ }^{\circ} \mathrm{C}$, a low pressure, and a vapor phase where $\mathrm{y}=0$ and $\mathrm{x}>0$. The yield and selectivity of $\mathrm{H}_{2}$ are influenced by the glycerol/water ratio; the higher it is, the greater the $\mathrm{H}_{2}$ production. However, costs related to water vaporization should be considered. The optimum value is influenced by the pressure and temperature [58]. Moreover, the higher the temperature is, the higher the production and selectivity of $\mathrm{H}_{2}$ is, although it can also involve a decrease in the heating value of the resulting gas [20,59]. In contrast, as was previously pointed out, the main disadvantage of this process is the generation of $\mathrm{CO}_{2}$ (which can be removed by in-situ adsorption), catalyst deactivation, and the high energy consumption [20,57]. Some authors have pointed out the possibility of re-using the $\mathrm{CO}_{2}$ produced in this process for other purposes, such as coupling $\mathrm{CO}_{2}$ desorption with methanation [18]. Another drawback is that many side reactions can take place, such as decomposition, methanation, and coke deposition, and depending on the operating conditions, these reactions can be noticeable [60].

For glycerol steam reforming, the main catalysts described are heterogeneous, and are similar to the ones used in other equivalent processes, such as methane steam reforming, especially in the case of supported noble and transition metal catalysts (with $\mathrm{Ni}$ as the most widely studied) $[60,61]$. As supports, different kinds of materials, such as alumina (such as $\mathrm{Ni} / \mathrm{Al}_{2} \mathrm{O}_{3}$ ), carbon $(\mathrm{Pt} / \mathrm{C}), \mathrm{Ce}$ and $\mathrm{Zr}$ oxides, and $\mathrm{Mg}$ oxides to a lesser extent, can be found in the literature [3,57]. Furthermore, perovskites based on $\mathrm{Co}$ and doped with $\mathrm{Au}, \mathrm{Ag}$, or Pt offered $\mathrm{H}_{2}$ generation ranging from 70 to $90 \%$ [3]. The effectiveness of these catalysts is variable, with those based on $\mathrm{Ni}, \mathrm{Ru}$, and $\mathrm{Rh}$ being the most effective ones.

Moreover, the role of the support is important, and its porosity, redox properties, and thermal stability, among others, need to be considered. Alumina is one of the most preferred among the common supports used for this kind of catalyst, due to its high thermal stability and specific surface [20]. However, the main problem related to heterogeneous catalysts is the possible catalyst deactivation due to coke or carbon deposition, apart from sintering and oxidation [61]. In order to solve this problem, some catalytic modifications (through glow discharge plasma, among others $[62,63]$ ) and pyrolytic pre-treatments before steam reforming have been considered, paying attention to $\mathrm{CeO}_{2}, \mathrm{ZrO}_{2}$ and $\mathrm{Mg}$ (II) as additives or promoters in order to avoid coke deposition by neutralizing the acidity of alumina, and promoting water adsorption and $\mathrm{O}-\mathrm{H}$ surface mobility $[3,20,60]$. Some mechanisms proposed in the literature for glycerol steam reforming are presented in Table 2. 
Table 2. Main reaction mechanisms in heterogeneous catalysts during steam reforming (proposed by Bagnato et al. [3]).

\begin{tabular}{cc}
\hline Catalyst & Mechanism \\
\hline Ni-based & $\begin{array}{r}\text { Glycerol is absorbed at the catalytic site and is dissociated in } \mathrm{H}_{2} \text { and hydroxyl. Afterwards, } \\
\text { hydroxyl reacts with } \mathrm{H}_{2} \text { to generate and release } \mathrm{H}_{2} \text { and } \mathrm{CO}_{2}\end{array}$ \\
Ru-based & $\begin{array}{r}\text { Glycerol is absorbed on the surface of the catalyst with water, creating a complex that reacts to } \\
\text { generate } \mathrm{H}_{2} \text { and } \mathrm{CO}_{2}\end{array}$ \\
Co-based & $\begin{array}{r}\text { Co acts as a precursor, promoting } \mathrm{H}_{2} \text { production and } \mathrm{CH}_{4} \text { and } \mathrm{CO}_{2} \text { generation } \\
\text { Pt-based }\end{array}$ \\
$\begin{array}{r}\text { Dehydrogenation of glycerol to form acetol, a second dehydrogenation step with a first breaking } \\
\text { of the C-C bond, and the formation of acetic acid, which decomposes into } \mathrm{H}_{2} \text { and } \mathrm{CO}_{2}\end{array}$ \\
\hline
\end{tabular}

Recent approaches to integrating steam reforming of the glycerol generated during the transesterification of vegetable oils have been considered. The use of this process (and the subsequent use of the corresponding catalysts) can contribute to the direct use of the hydrogen generated during SR of the glycerol obtained in transesterification. Therefore, hybrid-power generation can be an excellent electricity generation approach for the same biodiesel plant. For this purpose, some researchers applied it in the use of solid oxide fuel cells for this specific purpose, producing electricity and heat from clean chemical reactions without combustion (and subsequent low environmental contamination). As a conclusion, the efficiency of biodiesel plants was improved, also generating extra electrical energy for the power grid [46].

Therefore, steam reforming is still a useful way to make the most of glycerol. On the other hand, other techniques are used to produce $\mathrm{H}_{2}$ through steam reforming, such as membrane technology (see Figure 6). Hydrogen separation can take place through membrane technology, promoting glycerol conversion and hydrogen yields by altering the chemical equilibrium of the steam reforming reaction [64-66]. The use of membrane reactors implies the use of an operating unit to carry out the chemical reaction and the separation or purification process. Consequently, the chemical plants can become more compact and cheaper. In these facilities, the yield and conversion are higher than in conventional reactors, due to the selective removal of some products. Moreover, the addition of reagents is controlled through the membrane [3]. In this case, $\mathrm{H}_{2}$ permeates, depending on the temperature, pressure, and kind of material used in the membrane. There are many kinds of membranes available for this technique, such as macroporous, mesoporous, microporous, and dense membranes, including metallic membranes (made of Pd and alloys) to separate the generated $\mathrm{H}_{2}$. Therefore, recent studies used a Pd-Ag membrane reactor-some of them over an $\mathrm{Ni} / \mathrm{Al}_{2} \mathrm{O}_{3}$ catalyst-for this purpose $[66,67]$. Consequently, the membrane reactor improved glycerol conversion compared to traditional methods, being a method applicable to the large-scale production of $\mathrm{H}_{2}$ from waste glycerol. Other researchers used this technique, combined with $\mathrm{CO}_{2}$ sorbents (hydrotalcite), to increase the $\mathrm{H}_{2}$ yield and at the same time reduce the greenhouse effect gas evolution [68]. Consequently, the separated or combined use of membrane reactors and $\mathrm{CO}_{2}$ sorbents can be a suitable way of promoting glycerol steam reforming, improving the $\mathrm{H}_{2}$ yield of the process [69].

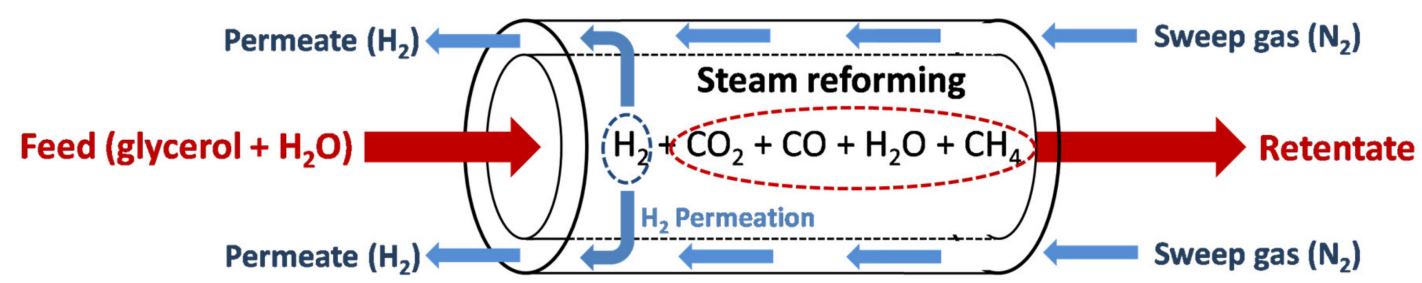

Figure 6. Basic representation of glycerol steam reforming in a membrane reactor, with the inner cylinder representing the membrane (inspired by Macedo et al. [65]).

Finally, in Table 3, the most recent and significant works on glycerol steam reforming are included, pointing out the kind of catalyst used and the main findings. 
Table 3. Recent uses of catalysts in glycerol steam reforming.

\begin{tabular}{|c|c|c|c|}
\hline Metal & Support & Observations & Reference \\
\hline $\mathrm{Ni}, \mathrm{Co}, \mathrm{Cu}, \mathrm{Fe}$ & Attapulgite & $\begin{array}{l}\text { Catalytic activity increased with temperature (up to } \\
700{ }^{\circ} \mathrm{C} \text { ), with } \mathrm{Ni} \text { and Co showing the best glycerol } \\
\text { conversion due to their capacity to promote the cleavage } \\
\text { of } \mathrm{C}-\mathrm{C} \text { and } \mathrm{C}-\mathrm{H} \text {. The main inactivation problems were } \\
\text { derived from metal sintering and coke deposition. }\end{array}$ & [70] \\
\hline $\mathrm{Ru}$ & Hydrotalcite & $\begin{array}{c}\text { High catalytic activity exceeding } 600{ }^{\circ} \mathrm{C} \text {. Deactivation } \\
\text { caused by coke deposition. }\end{array}$ & [71] \\
\hline Co and Co-Ce & Hydroxyapatite & $\begin{array}{l}\text { High selectivity toward } \mathrm{H}_{2}(83 \%) \text { at } 650^{\circ} \mathrm{C} \text {. Cerium } \\
\text { addition improved } \mathrm{H}_{2} \text { selectivity and glycerol } \\
\text { conversion, avoiding Co sintering. }\end{array}$ & [72] \\
\hline $\mathrm{Ni}$ and $\mathrm{Mg}$ & $\mathrm{Al}_{2} \mathrm{O}_{3}$ & $\begin{array}{l}\mathrm{Mg} \text { contributed to the dispersion of } \mathrm{Ni} \text {, increasing its } \\
\text { resistance of } \mathrm{Ni} \text { to sintering and coke deposition. }\end{array}$ & [73] \\
\hline $\mathrm{Co} / \mathrm{Al}$ & $\mathrm{SiO}_{2}, \mathrm{SiC}$, and $\gamma-\mathrm{Al}_{2} \mathrm{O}_{3}$ & $\begin{array}{c}\text { Oxidative steam reforming in a fixed bed reactor was } \\
\text { carried out, reaching heterogeneous thermal } \\
\text { decomposition of glycerol (at least } 83 \% \text { ) with the } \\
\text { three supports. }\end{array}$ & [74] \\
\hline $\mathrm{Rh}$ & $\mathrm{Al}_{2} \mathrm{O}_{3}$ & $\begin{array}{l}\text { The catalyst activity of the catalyst decreased over time, } \\
\text { solving this problem by oxidative regeneration to gasify } \\
\text { coke deposition. }\end{array}$ & [75] \\
\hline $\mathrm{Ni}$ & $\mathrm{CeO}_{2}$ & $\begin{array}{l}\text { Glow discharge plasma was used to prepare the catalyst, } \\
\text { increasing Ni dispersion, promoting the Ni-O-Ce } \\
\text { composite, and enhancing } \mathrm{H}_{2} \text { production and resistance } \\
\text { to coke deposition. }\end{array}$ & [62] \\
\hline $\mathrm{Ni}$ & $\mathrm{CeO}_{2}$ & $\begin{array}{c}\text { Glow discharge plasma improved } \mathrm{Ni} \text { dispersion, } \\
\text { hindering coke deposition and improving } \mathrm{H}_{2} \text { selectivity } \\
\text { and stability. }\end{array}$ & [63] \\
\hline $\mathrm{Ni}$ & $\mathrm{Al}_{2} \mathrm{O}_{3}$ & $\begin{array}{l}\text { In this work, glycerol steam reforming was used as a } \\
\text { starting point to produce methane, showing good } \\
\text { stability for a } 40 \% \text { glycerol aqueous solution. }\end{array}$ & [76] \\
\hline $\mathrm{Co}-\mathrm{Ni}$ & SBA-15 & $\begin{array}{c}\text { Different mesoporous catalysts were prepared, being } \\
\text { resistant to deactivation and yielding } 100 \% \\
\text { glycerol conversion. }\end{array}$ & [77] \\
\hline $\mathrm{Rh}$ & $\gamma-\mathrm{Al}_{2} \mathrm{O}_{3}$ & $\begin{array}{l}\text { The catalyst was modified with } \mathrm{CeO}_{2}, \mathrm{MgO} \text {, and } \mathrm{La}_{2} \mathrm{O}_{3} \\
\text { producing high glycerol conversions (over } 90 \% \text { ) and } \\
\text { sintering stability. }\end{array}$ & [78] \\
\hline $\mathrm{Ni}$ & Graphene & $\begin{array}{l}\text { Graphene-encapsulated nickel catalysts were } \\
\text { synthesized and attached to an } \mathrm{SiO}_{2} \text { skeleton, with rice } \\
\text { husk char as the carbonaceous source. Multilayered } \\
\text { graphene avoided oxidation and sintering of Ni, } \\
\text { not reducing its catalytic activity. }\end{array}$ & [79] \\
\hline $\mathrm{Ni}$ & $\mathrm{ZrO}_{2}$ & $\begin{array}{l}\text { Tetragonal zirconia support was compared to a } \\
\text { commercial monoclinic zirconia support, with the latter } \\
\text { providing a better } \mathrm{H}_{2} \text { yield and glycerol conversion. }\end{array}$ & [80] \\
\hline $\mathrm{Ni}$ & Hydrotalcite & $\begin{array}{l}\text { The effect of La promotion on this catalyst was studied, } \\
\text { influencing coke deposition. }\end{array}$ & [81] \\
\hline $\mathrm{Ni}$ & $\begin{array}{l}\text { CaO-modified } \\
\text { attapulgite }\end{array}$ & $\begin{array}{l}\mathrm{CaO} \text { increased the activity of the catalyst and the } \\
\text { inhibition of coke deposition, and attapulgite showed a } \\
\text { good carbon deposition resistance. }\end{array}$ & [82] \\
\hline $\mathrm{Ni}$ & Ce-modified $\gamma-\mathrm{Al}_{2} \mathrm{O}_{3}$ & $\begin{array}{l}\text { Ceria improved Ni dispersion, producing highly active } \\
\text { small Ni particles in the catalyst, showing high glycerol } \\
\text { conversion }(99 \%) \text { and } \mathrm{H}_{2} \text { yield }(62 \%) \text {. }\end{array}$ & [83] \\
\hline $\mathrm{NiCe}_{x} \mathrm{Al}$ & Metal oxides & $\begin{array}{l}\text { Ce addition restricted Ni agglomeration, enhancing } \\
\text { oxygen mobility, which improved the properties of } \mathrm{Ni} \\
\text { active sites, suppressing coke deposition. }\end{array}$ & [84] \\
\hline Co & $\mathrm{Al}_{2} \mathrm{O}_{3}$ & $\begin{array}{l}\text { The effect of niobia addition on this catalyst was studied, } \\
\text { decreasing alumina acidity, improving catalyst } \\
\text { reducibility, and reducing the formation of spinel phases. } \\
\text { MoO addition promoted stable } \mathrm{H}_{2} \text { vields. } \mathrm{Cu} \text { addition }\end{array}$ & [85] \\
\hline $\mathrm{Co}$ and $\mathrm{Cu}$ & $\mathrm{MgO}$ and $\mathrm{Al}_{2} \mathrm{O}_{3}$ & $\begin{array}{c}\text { suppressed coke deposition due to the smaller Co } \\
\text { particles obtained. }\end{array}$ & [86] \\
\hline $\mathrm{Ni}, \mathrm{La}$ and $\mathrm{Ce}$ & SAB-15 & $\begin{array}{l}\mathrm{La}_{2} \mathrm{O}_{3} \text { addition to } \mathrm{Ni} / \mathrm{SAB}-15 \text { avoided crystalline growth } \\
\text { of } \mathrm{Ni} \text {, and } \mathrm{CeO}_{2} \text { addition facilitated carbon removal. } \\
\text { The highest } \mathrm{H}_{2} \text { yield was obtained for the } 10 \% \mathrm{Ni} / 5 \% \\
\mathrm{La} / 5 \% \text { Ce catalyst. }\end{array}$ & [87] \\
\hline
\end{tabular}




\subsubsection{Aqueous Phase Reforming (APR)}

Compared to steam reforming, one of the main advantages of APR is that this process does not require vaporization of the feedstock, reducing the energy cost. Moreover, there is low CO production and few side reactions take place [88] if the aqueous phase reforming of glycerol is carried out (see Equation (2)):

$$
\mathrm{C}_{3} \mathrm{H}_{8} \mathrm{O}_{3}+3 \mathrm{H}_{2} \mathrm{O} \rightarrow 7 \mathrm{H}_{2}+3 \mathrm{CO}_{2} .
$$

In this case, the operating conditions are smoother (temperature between 220 and $250{ }^{\circ} \mathrm{C}$ and pressure at around $2 \mathrm{MPa}$ ), implying lower energy consumption. The main problem is related to the lower $\mathrm{H}_{2}$ selectivity and higher pressure requirements [57]. This chemical route can represent an alternative for gas phase glycerol reforming, especially when glycerol is dissolved in water. Developed a few years ago [89,90], APR can be used in several oxygenated substrates, and the thermal degradation is minimized because of the low temperatures used in this process. Moreover, it is safer because it uses aqueous solutions, and crude glycerol can be directly employed, reducing costs, as explained in previous sections. In this way, $\mathrm{H}_{2}$ is generated, reducing the formation of $\mathrm{CO}_{2}, \mathrm{CO}, \mathrm{CH}_{4}$, or alkanes in the gas phase. On the other hand, other oxygenated compounds, such as alcohols, aldehydes, and carboxylic acids can be obtained in the liquid phase.

The main requirements for obtaining a suitable catalyst in APR are the following [57]:

- Glycerol should be adsorbed over the active metal sites of the catalyst;

- It should have $\mathrm{C}-\mathrm{C}, \mathrm{O}-\mathrm{H}$, and $\mathrm{C}-\mathrm{H}$ cleavage and facilitate a water-gas shift reaction (desorbing $\mathrm{CO}$ from the catalyst surface, with low activity in C-O cleavage [91]). Additionally, Fischer-Tropsch and methanation reactions should be avoided [92];

- It usually contains VIII group metals, or they can be bimetallic catalysts. Moreover, the use of Ni-based catalysts and other $X$ group metals is frequent due to their activity and selectivity $[20,93]$;

- It should have good support properties (dispersion of the active phase, co-catalytic sites, etc.);

- If possible, its cost should be low.

The catalytic supports that are normally used in research are alumina and silica, although some catalysts can be supported on active carbon, nanotubes, mesoporous carbon, nanoparticles, etc. On the other hand, the use of Ce or Ce-Zr oxides provides good results, due to the good thermal and mechanical resistance and redox properties of $\mathrm{Ce}$. Moreover, $\mathrm{Mg}$ and $\mathrm{Mg}$ - $\mathrm{Al}$ oxides are used to provide basic sites for the catalyst, improving $\mathrm{H}_{2}$ formation and limiting hydrocarbon production and subsequent coke deposition on the catalyst surface, as many studies have pointed out $[57,91,93]$. On the contrary, the higher the acidity of the catalyst, the higher their affinity for coke deposition [20]. This fact can also enhance the stability of metal supported catalysts against sintering. Table 4 shows the main trends regarding catalysts used in aqueous phase reforming. It should be noted that one interesting trend is the direct use of the $\mathrm{H}_{2}$ produced in aqueous steam reforming of glycerol for other purposes, such as hydrogenolysis, hydrogenation, and methane production [94-96].

Table 4. Catalysts recently used in glycerol aqueous phase reforming.

\begin{tabular}{|c|c|c|c|}
\hline Metal & Support & Observations & Reference \\
\hline $\mathrm{Pt}-\mathrm{Mn}$ & $\mathrm{C}$ & $\begin{array}{l}\text { The promoting effect of } \mathrm{Mg} \text { on } \mathrm{H}_{2} \text { production was studied in } \\
\text { steam and aqueous phase reforming, showing a good } \\
\text { performance, especially for } \mathrm{SR} \text {, and being a cheap option. }\end{array}$ & [93] \\
\hline $\mathrm{Ni}$ & $\mathrm{Al}_{2} \mathrm{O}_{3} / \mathrm{MgO}$ & $\begin{array}{l}\mathrm{MgO} \text { addition improved the catalytic activity. The Al/Mg ratio } \\
\text { was vital in the performance of the catalyst. No evidence of } \\
\text { deactivation by carbon deposition was observed. }\end{array}$ & [91] \\
\hline $\mathrm{Pt}$ & $\mathrm{Al}_{2} \mathrm{O}_{3}$ & $\begin{array}{l}\text { A Pt nanoparticle supported on alumina was used, varying } \\
\text { the particle size. Therefore, the best conversion of glycerol } \\
\text { was obtained for the larger particle size. }\end{array}$ & [97] \\
\hline $\mathrm{Ir}-\mathrm{ReO}_{\mathrm{x}}$ & $\mathrm{SiO}_{2}$ & $\begin{array}{l}\mathrm{H}_{2} \text { generated in aqueous steam reforming was used for the } \\
\text { selective C-O hydrogenolysis of glycerol (without external } \\
\qquad \mathrm{H}_{2} \text { sources). }\end{array}$ & [95] \\
\hline
\end{tabular}


Table 4. Cont.

\begin{tabular}{|c|c|c|c|}
\hline Metal & Support & Observations & Reference \\
\hline Raney $\mathrm{Ni}^{\circledR}$ & - & $\begin{array}{c}\text { In-situ glycerol aqueous phase reforming and phenol } \\
\text { hydrogenation. }\end{array}$ & [94] \\
\hline Co aluminate spinel & - & $\begin{array}{l}\text { High performance when methanation and Fischer-Tropsch } \\
\text { are inhibited. }\end{array}$ & [92] \\
\hline $\mathrm{Ni}$ aluminate spinel & - & $\begin{array}{l}\text { Bulk nickel aluminate spinel prepared by co-precipitation at } \\
850{ }^{\circ} \mathrm{C} \text {, reaching } 93 \% \text { glycerol conversion and } 57 \% \text { conversion } \\
\text { to gas. }\end{array}$ & [98] \\
\hline $\mathrm{Pt} / \mathrm{CoAl}_{2} \mathrm{O}_{4}$ & - & $\begin{array}{l}\text { Bimetallic catalyst showed higher activity (with synergistic } \\
\text { effect between Pt and Co) than monometallic catalysts. }\end{array}$ & [99] \\
\hline $\mathrm{Pt}$ & $\mathrm{Al}_{2} \mathrm{O}_{3} / \mathrm{MgO}$ & $\begin{array}{c}\text { Aqueous phase glycerol reforming coupled to } \\
\text { methanol synthesis. }\end{array}$ & [96] \\
\hline
\end{tabular}

\subsubsection{Dry Reforming}

This kind of reforming is based on the reaction of glycerol with carbon dioxide to produce hydrogen, with temperatures above $500{ }^{\circ} \mathrm{C}$. It should be noted that the use of carbon dioxide as a reagent could be a suitable way to mitigate greenhouse gases in the environment. Therefore, industries where considerable amounts of carbon dioxide are produced can take advantage of this technology. This fact, combined with the management of glycerol, makes it an environmentally friendly process $[56,100]$. The reaction is summed up in Equation (3).

$$
\mathrm{C}_{3} \mathrm{H}_{8} \mathrm{O}_{3}+\mathrm{CO}_{2} \leftrightarrow 4 \mathrm{CO}+3 \mathrm{H}_{2}+\mathrm{H}_{2} \mathrm{O}
$$

Depending on the chemical conditions, other side reactions can take place, such as glycerol decomposition, methanation, and a reverse water-gas shift reaction. Therefore, the optimum conditions for glycerol dry reforming are atmospheric pressure, $1000 \mathrm{~K}$, and a 1:1 carbon dioxide/glycerol ratio, producing $6.4 \mathrm{~mol}$ of syngas per mol of glycerol [100].

For dry reforming, different catalysts can be used, highlighting Ni, Rh, Ru, Ir, Pd, or Pt [20,100-104], with coke accumulation and the sintering of catalyst particles (especially for Rh) as the main disadvantages, as in other cases [20]. In order to avoid coke accumulation, La was added to these catalysts to promote active sites, due to its redox property to remove carbon and its lower acidity compared to other popular catalysts such as $\mathrm{Ni}$ [100]. Additionally, the use of supports such as $\mathrm{MgO}$ and $\mathrm{CaO}$ can increase the carbon resistance within the catalyst, reducing carbon deposition [105]. On the other hand, $\mathrm{ZrO}_{2}$ and $\mathrm{CeO}_{2}$ represent promising materials as supports for the dry reforming of glycerol, due to their oxygen transfer properties, helping in the dissociation of $\mathrm{CO}_{2}$ into $\mathrm{CO}$ and O [104].

\section{Hydrogenolysis and Reduction Processes}

When APR reaction conditions are sufficiently softened, it enters competition with the hydrogenolysis processes [106]. In terms of the chemical reaction, the glycerol hydrogenolysis process supposes a dehydroxylation of glycerol, involving the rupture of a $\mathrm{C}-\mathrm{OH}$ bond in the molecule by the interaction of a $\mathrm{H}_{2}$ molecule. The reaction mechanism can be described as $\mathrm{pH}$ dependent; under acid or neutral conditions, a Dehydration-Hydrogenation mechanism explains the intermediaries as acetol (hydroxyacetone), which is a glycerol dehydration product favored by Lewis acid sites [107], while a Dehydrogenation-Dehydration-Hydrogenation sequence fits better under basic conditions (Figure 7). This $\mathrm{H}_{2}$ molecule can usually be proportioned in the gas phase or generated in situ from a hydrogen donor. Among the different chemicals than can be obtained, propanediols can be considered the most interesting products from an industrial point of view due to their versatility as platform molecules. For instance, 1,2-Propanediol (1,2-PDO) is the main product obtained and can be used in a wide range of industries, from pharmaceuticals to antifreeze, and its isomer 1,3-Propanediol (1,3-PDO) is the kinetic product and valuable in the polymer industry $[2,108,109]$. The lack of selectivity is 
commonly due to the hydrogenolysis of propanediols until the generation of 1- or 2-propanols or paraffin and the competence with the aqueous phase reforming process, able to decompose glycerol into $\mathrm{CO}_{2}$ and $\mathrm{H}_{2}$ under similar reaction conditions. Figure 7 shows the most probable reaction pathways under hydrogenolysis conditions.

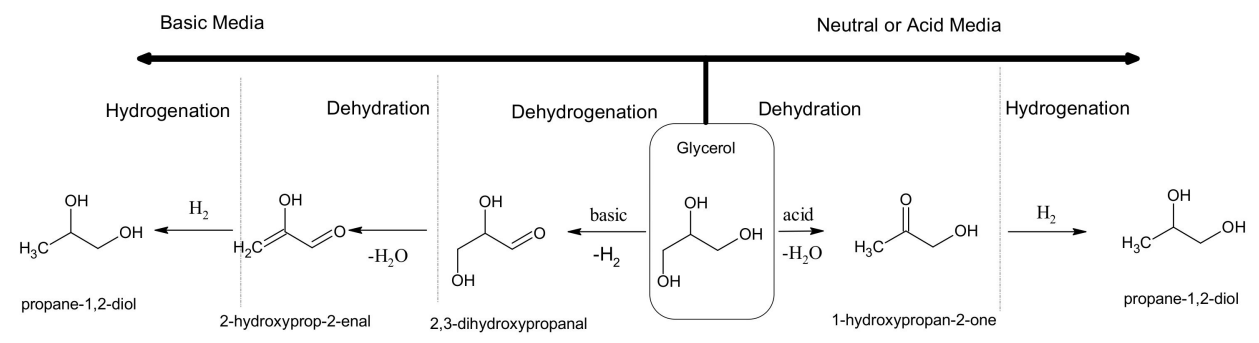

Figure 7. Proposed mechanism for 1,2-Propanediol (1,2-PDO) production.

Metal-acid bifunctional catalysts have been described as the most effective ones for glycerol hydrogenolysis. A proper combination of an acid surface character and a metallic phase increases both the conversion and selectivity to desired products by tuning the different catalyst properties that affect the reaction [110-113]. A tuneable acidity can be generated through support synthesis methodologies that induce oxygen vacancies in the material, and these have been studied in different works concerning the influence of the support in the reaction [114]. Among them, materials such as carbon [115-117], metal oxides [118-125], zeolites [116,126-131], and mixed oxides [120,132-135] that exhibited high acidity were applied, in order to benefit the dehydration step $[120,128,136]$. In these cases, selectivity to 1,2-PDO can be explained if glycerol adsorption over support acid sites controlled by a steric effect is considered. Then, the terminal $\mathrm{C}-\mathrm{OH}$ can be dissociated in a dehydration reaction to produce acetol, which can be reduced over a metallic site into 1,2-PDO [109,137]. On the contrary, when the reaction is carried out under basic conditions, glycerol dehydrogenation over metallic particles to form glyceraldehyde is the initiation step, evolving to produce 1,2-PDO after a dehydration-hydrogenation sequence (Figure 8) $[109,137]$ or lactic acid (LA) via the Cannizzaro reaction [138].

As active metals in glycerol hydrogenolysis catalysts, the activity of Ir-, $\mathrm{Pd}-, \mathrm{Ru}-$-, and Pt-based noble metals has been widely reported $[108,139,140]$. However, recent advances have focused on catalyst cost reduction, and efforts have especially focused on a supported $\mathrm{Cu}$-based catalyst that has reported nearly complete glycerol conversions and 1,2-PDO yields higher than $80 \%$ [122,129,141-144]. In this sense, the work of Gatti et al. [145], with Ni supported over $\gamma-\mathrm{Al}_{2} \mathrm{O}_{3}$ and a phosphorous-impregnated carbon composite in a consecutive treatment of crude glycerol, reached total conversion and yields of $87 \% 1,2-\mathrm{PDO}$ in the first reaction with $\mathrm{Ni} / \gamma-\mathrm{Al}_{2} \mathrm{O}_{3}$ and, after the second hydrogenolysis reaction, obtained 1-PrOH with a 79\% yield.

Special attention must be paid when oxophilic metals such as $\mathrm{MoO}_{\mathrm{x}}, \mathrm{CrO}_{\mathrm{x}}$, and $\mathrm{WO}_{\mathrm{x}}$ are incorporated in the support. In general, with a metallic phase in the presence of $\mathrm{WO}_{\mathrm{x}}$ as a dopant or modifier, the alternative reaction mechanism proposed in Figure 9 is allowed and the kinetic product 1,3-PDO can be found in the reaction media [114,133,146-149]. According to Aihara et al. [150], a relationship between $\mathrm{WO}_{\mathrm{x}}$ 's positive effect in a 1,3-PDO yield and the modifier loading can be established as a perimeter interface length dependence in a $\mathrm{Pt} / \mathrm{WO}_{3} / \mathrm{Al}_{2} \mathrm{O}_{3}$ catalyst. This fact confirms that when $\mathrm{W}$ is deposited over alumina, a $\mathrm{WO}_{\mathrm{x}}$ monolayer with $\mathrm{W}-(\mathrm{OH})-\mathrm{Al}$ active sites in the layer perimeter can be formed when the $\mathrm{WO}_{\mathrm{x}}$ loading is less than $20 \%$, and the maximum yield of 1,3-PDO can be obtained with $\mathrm{W}$ loadings between 5 and $10 \%$, associated with the higher interface length exposed to the reaction. In some cases, several lixiviation problems were detected when aqueous phase was analyzed by ICP-MS [120]. Some authors such as Wang et al. [151] have dealt with this problem through the incorporation of other elements, such as $\mathrm{Mg}$ in a $\mathrm{Pt} / \mathrm{WO}_{\mathrm{x}}-\mathrm{ZrO}_{2}$ catalyst, obtaining a quaternary catalyst. 


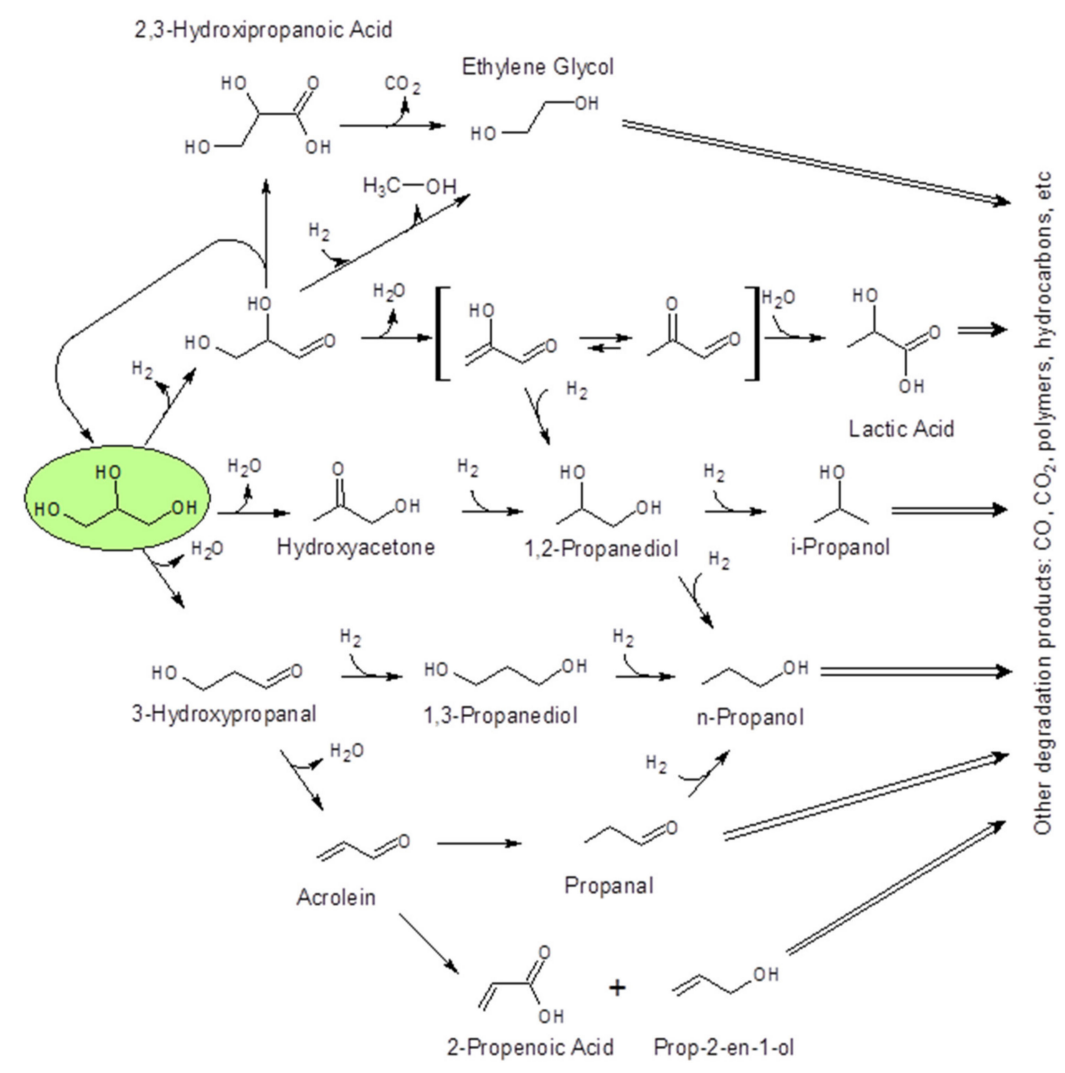

Figure 8. Different main products observed in glycerol (green) hydrogenolysis.
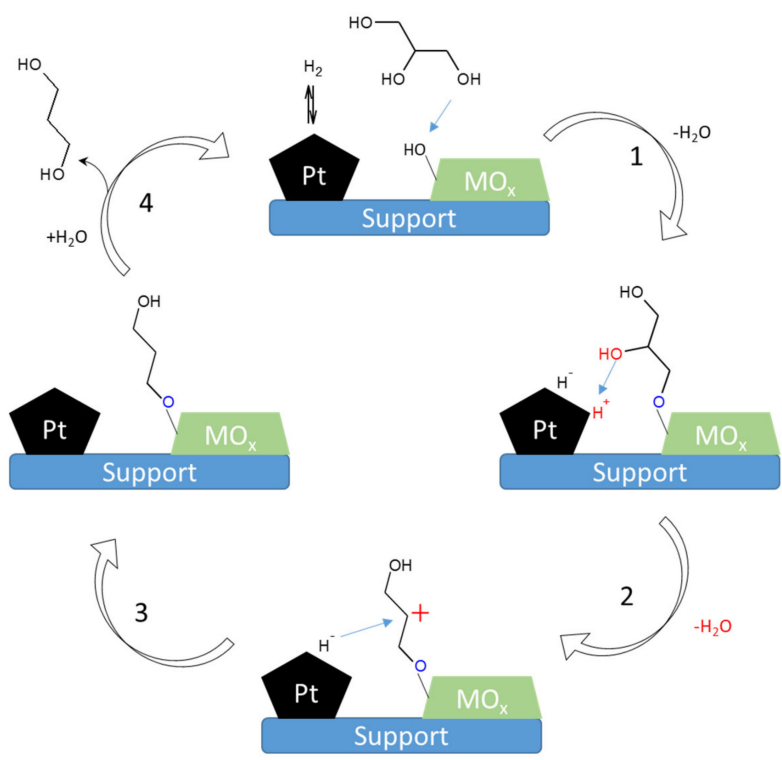

Figure 9. Proposed mechanism for 1,3-Propanediol (1,3-PDO) production in the presence of oxophilic metals $\left(\mathrm{MO}_{\mathrm{x}}\right)$ and $\mathrm{Pt}$ as the metallic phase.

Two typical catalyst groups can be found in the literature as a function of the desired product concerning the metallic phase involving glycerol hydrogenolysis. On one hand, transition metals such as $\mathrm{Co}^{-}, \mathrm{Ni}-$, and $\mathrm{Cu}$-based catalysts can be applied in both liquid and gas phase reaction systems. Aiming at 1,2-PDO production, $\mathrm{Cu}$ exhibits a higher selectivity than $\mathrm{Ni}$, as can be observed in Table 5. Nevertheless, an Ni catalyst usually shows a tendency for deep hydrogenolysis, leading to monoalcohols 1-Propanol (1-PrOH) and 2-Propanol (2-PrOH), C-C cleavage to generate ethylene glycol (EG) or, as a last resort, methane under the appropriate conditions [147]. 
Table 5. Recent catalysts employed for glycerol hydrogenolysis.

\begin{tabular}{|c|c|c|c|c|c|c|}
\hline Catalyst & Reaction Conditions & Glycerol Conversion \% & $\begin{array}{l}\text { 1,2-PDO } \\
\text { Yield } \%\end{array}$ & $\begin{array}{l}\text { 1,3-PDO } \\
\text { Yield } \%\end{array}$ & $\begin{array}{l}\text { Other Main Products' } \\
\text { (Yield, \%) }\end{array}$ & Ref. \\
\hline $\mathrm{Ni} / \mathrm{WO}_{3}-\mathrm{TiO}_{2}$ & $\begin{array}{l}\text { Vcat. }=2 \mathrm{~mL} .30 \% \text { glycerol aq. } 3.0 \mathrm{MPa} \mathrm{H}_{2} \cdot 250^{\circ} \mathrm{C} . \\
\text { LHSV }=0.46 \mathrm{~h}^{-1} \text {. gas flow } 15 \mathrm{~mL} \mathrm{~min}^{-1} .\end{array}$ & 100 & & & monopropanols (94.0) & [147] \\
\hline $\mathrm{Ni}-\mathrm{Cu} / \mathrm{Y}$-zeolite & $\begin{array}{l}1.25 \mathrm{~g} \text { catalyst. } 20 \mathrm{vol} \% \text { glycerol aq. feed rate } 0.041 \mathrm{~mL} \mathrm{~min}^{-1} . \\
260^{\circ} \mathrm{C} .46 \text { bar. } 30 \mathrm{~h} .\end{array}$ & 96.4 & 31.8 & & LA (29.4) & [127] \\
\hline $\mathrm{Cu}-\mathrm{Ni} / \gamma-\mathrm{Al}_{2} \mathrm{O}_{3}$ & $\begin{array}{c}20 \mathrm{wt} \% \text { glycerol aq. feed rate }=0.03 \mathrm{~mL} / \mathrm{min} .220^{\circ} \mathrm{C} .0 .75 \mathrm{MPa} . \\
\text { WHSV }=1.3 \mathrm{~h}^{-1} . \mathrm{H}_{2} \text { flow rate }=100 \mathrm{~mL} / \mathrm{min} . \\
\mathrm{N}_{2} \text { flow rate }=20 \mathrm{~mL} / \mathrm{min} .14 \mathrm{~h} .\end{array}$ & 99.9 & 89.4 & & & [141] \\
\hline Hydrotalcite-Cu & Glycerol/catalyst ratio of $12: 1$ w/w $200^{\circ} \mathrm{C} .3 .4 \mathrm{MPa} .24 \mathrm{~h}$ & 66 & 63.1 & & & [152] \\
\hline $\mathrm{Cu} / \mathrm{Ce}_{3} / \mathrm{Mg}$ & $\begin{array}{l}1 \mathrm{~g} \text { of reduced catalyst, } 50 \mathrm{~g} \text { of } 20 \mathrm{wt} . \% \text { Glycerol aq. } 473 \mathrm{~K} .60 \mathrm{bar} \\
\text { of } \mathrm{H}_{2} \text { pressure, } 10 \mathrm{~h} \text {. }\end{array}$ & 56.4 & 54.9 & & & [153] \\
\hline $\mathrm{Ni}-\mathrm{Zr} / \mathrm{H}$-beta zeolite & 0.5 g catalyst. $40 \mathrm{~mL} 50 \mathrm{wt} \%$ glycerol aq. $200{ }^{\circ} \mathrm{C} .600 \mathrm{psi} \mathrm{H}_{2} .10 \mathrm{~h}$. & 77 & 20 & 10.8 & Monopropanols (39.3) & [154] \\
\hline $\mathrm{W} / \mathrm{Al}_{2} \mathrm{O}_{3}$ & $\begin{array}{c}3 \mathrm{~mL} \text { catalyst bed. } 60 \mathrm{wt} \% \text { glycerol/ } / \mathrm{H}_{2} \mathrm{O} 10 \mathrm{~h}^{-1} \text { LHSV. } 60 \text { bar } \mathrm{H}_{2} \\
1860 \mathrm{~h}^{-1} \text { GHSV. } 325^{\circ} \mathrm{C}\end{array}$ & 73 & 7.3 & & Monopropanols (51.5) & [155] \\
\hline $\begin{array}{l}\mathrm{Ni} / \gamma-\mathrm{Al}_{2} \mathrm{O}_{3} \text { and } \\
\quad \mathrm{Ni} / \mathrm{CS}-\mathrm{P}\end{array}$ & $\begin{array}{c}\text { Catalyst/glycerol }=0.16 \text { (mass ratio). Ni/ } /-\mathrm{Al}_{2} \mathrm{O}_{3} \text { catalyst } 5 \mathrm{~h} \\
220^{\circ} \mathrm{C}(\mathrm{a}), \text { followed by Ni/CS-P catalyst } 2 \mathrm{~h} \text { at } 260^{\circ} \mathrm{C}(\mathrm{b}) . \\
6.5 \mathrm{MPa} \mathrm{H}_{2} . \text { Crude glycerol Oleomud. }\end{array}$ & 100 & (a) 87 & & (b) 1-PrOH (79) & [145] \\
\hline $5 \mathrm{Cu}-1 \mathrm{~B} / \mathrm{Al}_{2} \mathrm{O}_{3}$ & $\begin{array}{l}2.0 \text { g catalyst. } 0.1 \mathrm{~h}-1 \mathrm{WHSV} 10 \% \text { crude glycerol aq. } 250^{\circ} \mathrm{C} \text {, } \\
\qquad 6 \mathrm{MPa} \mathrm{H}_{2} .\end{array}$ & 70 & 56 & & Acetol (3.5) & [156] \\
\hline $10 \% \mathrm{Cu} / \mathrm{SBA}-15(\mathrm{G})$ & $\begin{array}{c}\text { Catalyst/glycerol }=1: 10 \text { weight ratio. } 6.67 \mathrm{~g} \mathrm{n} \text {-butanol solution of } \\
\text { glycerol }(12 \mathrm{wt} \%) .4 .0 \mathrm{MPa} \mathrm{H}_{2} .483 \mathrm{~K} .6 \mathrm{~h}\end{array}$ & 90 & 88.2 & & & [122] \\
\hline $\mathrm{Ni} / \mathrm{ZnAl}$ & $\begin{array}{c}100 \mathrm{mg} \text { of catalyst. Feed: } 3.5 \mathrm{~mL} \mathrm{~h}^{-1} \text { of } 3 \% \text { glycerol aq. gas feed } \\
5 \% \mathrm{H}_{2} / \mathrm{Ar} \text {. atmospheric pressure. } 573 \mathrm{~K} \text {. }\end{array}$ & 100 & & & Methane (100) & [138] \\
\hline $10 \mathrm{Cu}-7 \mathrm{Co} / \gamma-\mathrm{Al}_{2} \mathrm{O}_{3}$ & $\begin{array}{c}1 \mathrm{~g} \text { of catalyst. } 200^{\circ} \mathrm{C} \text {. flow rate LHSV of } 2.5 \mathrm{~h}^{-1} .20 \mathrm{wt} \% \\
\text { Glycerol aq. } 3 \mathrm{~h}\end{array}$ & 100 & 77 & & & [142] \\
\hline $5 \mathrm{CuO} / \mathrm{Mg}_{9} \mathrm{Al}_{2.7}-\mathrm{Ga}_{2.3} \mathrm{O}_{2}$ & $\begin{array}{c}0.5 \mathrm{~g} \text { catalyst, } 20 \mathrm{wt} . \% \text { glycerol } 220{ }^{\circ} \mathrm{C} .0 .5 \mathrm{MPa} \mathrm{H}_{2} \text { at } \\
40 \mathrm{~mL} \cdot \mathrm{min}^{-1} .\end{array}$ & 100 & 98 & & & [143] \\
\hline 5Co-MSAPO-11 & Catalyst $1 \mathrm{~g}, 5 \mathrm{~g}$ glycerol, $60 \mathrm{~g}$ water. $4.0 \mathrm{MPa} \mathrm{H}_{2} .210^{\circ} \mathrm{C}, 8 \mathrm{~h}$. & 67.1 & 63.6 & & & [130] \\
\hline $\mathrm{Cu}_{2} \mathrm{Ni} / \mathrm{M}-\mathrm{SAPO}-11$ & $0.5 \mathrm{~g}$ catalyst. $75 \mathrm{~mL}$ of $8 \mathrm{wt} \%$ glycerol aq. $4 \mathrm{MPa} \mathrm{H}_{2} .230^{\circ} \mathrm{C} .12 \mathrm{~h}$ & 95 & 94 & & & [129] \\
\hline $\begin{array}{l}\mathrm{PtCu}(\text { Single Atom } \\
\text { Alloy)/MgAl }\end{array}$ & $\begin{array}{l}0.14 \mathrm{~g} \text { catalyst. } 10 \mathrm{~mL} \text { of glycerol alcoholic solution (10 wt.\%). } \\
\qquad 200{ }^{\circ} \mathrm{C} \text {. and } 2.0 \mathrm{MPa} \text { of } \mathrm{H}_{2}, 8 \mathrm{~h} \text {. }\end{array}$ & 100 & 99.2 & & & [144] \\
\hline PtRu/Zn3Ce1 & 0.05 g catalyst. $15 \mathrm{~mL} 0.3 \mathrm{M}$ glycerol aq. $1 \mathrm{MPa} \mathrm{N} 2.220^{\circ} \mathrm{C}, 4 \mathrm{~h}$ & 46.4 & 13.92 & & $\begin{array}{c}\text { LA }(9.28) \\
\text { Acetol }(11.6)\end{array}$ & [157] \\
\hline $8 \mathrm{Nb} / \mathrm{Pd}-\mathrm{Zr}-\mathrm{Al}$ & $\begin{array}{c}0.20 \mathrm{~g} \text { catalyst, } 20 \mathrm{~g} \text { of } 10 \mathrm{wt} \% \text { glycerol aq., } 200{ }^{\circ} \mathrm{C} \text {; initial } \mathrm{H}_{2} \\
\text { pressure. } 3.5 \mathrm{MPa} ; 8 \mathrm{~h}\end{array}$ & 69.2 & 58.4 & & & [158] \\
\hline $\mathrm{Ru} /$ Mordenite & 0.4 g catalyst. 0.5 g glycerol. 9 g i-PrOH. $0.5 \mathrm{MPa} \mathrm{N}_{2} .140{ }^{\circ} \mathrm{C} .72 \mathrm{~h}$. & 70 & & & $\begin{array}{l}\text { 2-isopropoxy-propan-1-ol } \\
\text { (70.0) }\end{array}$ & [159] \\
\hline $\mathrm{PtWZr}_{3} \mathrm{Ti}_{7}$ & $\begin{array}{c}4 \text { g catalyst. } 50 \mathrm{wt} \% \text { glycerol aq. Feed: } 0.03 \mathrm{~mL} / \mathrm{min} . \\
\mathrm{H}_{2}: \text { glycerol: } \mathrm{H}_{2} \mathrm{O}=10: 1: 5.1 \text { (molar ratio). } 5 \mathrm{MPa} .140^{\circ} \mathrm{C} .15 \mathrm{~h} .\end{array}$ & 73.8 & & 25.3 & 1-PrOH (42.3) & {$[135,160]$} \\
\hline
\end{tabular}


Table 5. Cont.

\begin{tabular}{|c|c|c|c|c|c|c|}
\hline Catalyst & Reaction Conditions & Glycerol Conversion \% & $\begin{array}{l}\text { 1,2-PDO } \\
\text { Yield } \%\end{array}$ & $\begin{array}{l}\text { 1,3-PDO } \\
\text { Yield } \%\end{array}$ & $\begin{array}{l}\text { Other Main Products' } \\
\text { (Yield, \%) }\end{array}$ & Ref. \\
\hline $2 \mathrm{wt} \% \mathrm{Pt} / \mathrm{WO}_{\mathrm{x}}$ & $\begin{array}{c}0.3 \text { g catalyst. } 12 \text { g } 5 \mathrm{wt} \% \text { glycerol aq. } 140{ }^{\circ} \mathrm{C} .1 \mathrm{MPa} \mathrm{H}_{2} . \\
800 \mathrm{rpm} .12 \mathrm{~h} .\end{array}$ & 37.4 & 0.8 & 13.1 & 1-PrOH (18.8) & {$[114]$} \\
\hline 5Pt/W-s-SBA-15 & $\begin{array}{c}0.4 \mathrm{~g} \text { of catalyst. } 4.0 \mathrm{~g} \text { of } 30 \mathrm{wt} \% \text { glycerol aq. } 433 \mathrm{~K} .4 .0 \mathrm{MPa} \mathrm{H}_{2} \\
24 \mathrm{~h} .\end{array}$ & 76.8 & & 47.4 & 1-PrOH (22.0) & {$[161]$} \\
\hline $\mathrm{Pt} / 0.50 \mathrm{Mg} / \mathrm{WO}_{\mathrm{x}}-\mathrm{ZrO}_{2}$ & $\begin{array}{l}3.5 \mathrm{~g} \text { catalyst. } 4 \mathrm{MPa} .150{ }^{\circ} \mathrm{C} \text {. Feed: } 40 \mathrm{wt} \% \text { glycerol aq. } \\
\text { WHSV }=0.2 \mathrm{~h}^{-1} . \mathrm{H}_{2} \text { flow } 50 \mathrm{~mL} \mathrm{~min}^{-1} . \text { Time on stream } 25 \mathrm{~h}\end{array}$ & 52.9 & 3.9 & 32.1 & $\begin{array}{l}\text { 1-PrOH (8.3) } \\
\text { 2-PrOH (7.9) }\end{array}$ & {$[151]$} \\
\hline $6 \mathrm{Pt} / 12.9 \mathrm{~W} / \mathrm{Al}_{2} \mathrm{O}_{3}$ & $\begin{array}{c}\text { Catalyst volume } 2.0 \mathrm{~mL}, 50 \mathrm{wt} \% \text { GLY. GHSV }=1000 \mathrm{~h}^{-1} .5 .0 \mathrm{MPa} \\
\mathrm{H}_{2}, 180^{\circ} \mathrm{C} .\end{array}$ & 80.4 & 4 & 28.4 & $\begin{array}{l}\text { 1-PrOH (33.6) } \\
\text { 2-PrOH (9.9) }\end{array}$ & [162] \\
\hline $2 \mathrm{Pt} / 20(\mathrm{~W}+\mathrm{Al})-\mathrm{SBA}-15$ & $\begin{array}{c}0.5 \mathrm{~g} \text { of catalyst. } 25 \mathrm{~g} 3 \mathrm{wt} \% \text { glycerol aq. } 160^{\circ} \mathrm{C} .6 \mathrm{MPa} \mathrm{H}_{2} \text { for } \\
\text { initial pressure. } 12 \mathrm{~h} .\end{array}$ & 65 & & 32.5 & 1-PrOH (29.2) & [163] \\
\hline \multirow{2}{*}{$\begin{array}{l}\mathrm{Pt} / \mathrm{ZrW} 38 \mathrm{Mn} 3 \\
\mathrm{Ir}-\mathrm{ReO}_{\mathrm{x}} / \mathrm{Rutile} \\
\mathrm{Re} / \mathrm{Ir}=0.30\end{array}$} & \multirow{2}{*}{$\begin{array}{l}0.5 \mathrm{~g} \text { catalyst. } 4.0 \mathrm{~g} \text { glycerol. } 36.0 \mathrm{~g} \text { water. } 180^{\circ} \mathrm{C} .8 \mathrm{MPa} .18 \mathrm{~h} \text {. } \\
\text { Catalyst amount }=150 \mathrm{mg} .4 \mathrm{~g} \text { glycerol. } 2 \mathrm{~g} \mathrm{H}_{2} \mathrm{O} .8 \mathrm{MPa} \mathrm{H} \mathrm{H}_{2} \\
\qquad \mathrm{~T}=393 \mathrm{~K} . \mathrm{t}=4 \mathrm{~h} .\end{array}$} & 55 & 5.5 & 24.8 & (22) & {$[164]$} \\
\hline & & 52 & & 29.6 & 1-PrOH (17.7) & {$[165]$} \\
\hline
\end{tabular}


On the other hand, noble metal catalysts such as $\mathrm{Ru}, \mathrm{Pt}$, and Re are quite common as a resource employed to prompt 1,2-PDO production $[128,166]$. However, their high activity leads to selectivity decay that justifies the study and employment of $\mathrm{Cu}$ and $\mathrm{Ni}$ catalysts, which provide reasonable yields for 1,2-PDO at lower production costs. From a 1,3-PDO production point of view, noble metals represent the metallic phase most preferred, with Pt being the most effective among them, probably due to the possibility of dehydrogenation process deactivation. As noted above, noble metal- $\mathrm{WO}_{\mathrm{x}}$ synergism for 1,3-PDO production has been reported since 2004, when Chaminand et al. used $\mathrm{H}_{2} \mathrm{WO}_{4}$ as an additive in glycerol hydrogenolysis with an $\mathrm{Rh} / \mathrm{C}$ catalyst [167]. Despite the fact that the conversion observed was quite low, at around 10\%, selectivity values of 26 and 52\% were reached for 1,3- and 1,2-PDO, respectively. Therefore, several catalytic systems were designed and tested under mild hydrothermal conditions, with selectivity values of around $60 \%$ associated with low conversions. In the literature, higher yields were found for $\mathrm{Pt}_{-} \mathrm{WO}_{\mathrm{x}}$ supported over $\mathrm{Al}$ derivatives, exhibiting values of $66-69 \%$ and 62\%, reported by Kaneda et al. in 2013 [148] and Zong et al. in 2017 [168], respectively. Different strategies can be applied to overcome the lack of activity of Pt-W systems at the cost of selectivity, from the incorporation of other elements in the catalyst to external additives such as $\mathrm{NaOH}$ to achieve higher conversion rates.

Future research on glycerol hydrogenolysis should be focused, in terms of 1,2-PDO production, on the development of advanced transition metal-based catalysts able to perform the reaction under mild conditions, even with crude glycerol. From a 1,3-PDO point of view, more research is required to achieve competitive reaction yields, despite a patent being published for a Pt-W-Zr catalyst [169] for 1,3-PDO production [170] this year. In both cases, bimetallic systems may represent a key improvement factor. Overhydrogenolysis is considered a problem that needs to be overcome; however, the production of other products, such as monopropanols, propene, and C2 compounds, can be stablished as a model reaction for the valorization of other polyols. Finally, in terms of real applicability, Jiménez et al. demonstrated that fully renewable 1,2-PDO production increases production costs by $16 \%$ with respect to the partial renewable process and, depending on markets, a real application is possible [17].

\section{Glycerol Selective Oxidation}

During the most recent few decades, selective oxidation has been considered a one competitive glycerol valorization pathway. The reaction leads to molecules with high $\mathrm{O} / \mathrm{C}$ ratios and has received special attention, for example, from the polymer, chemical, and pharmaceutical industry (Figure 10) [171]. Glycerol's interactions with catalyst active sites and reaction conditions are key to unravelling the reaction pathway, and as described in the hydrogenolysis section, glycerol oxidation can start through two different mechanisms: Dehydration and dehydrogenation.

Despite glycerol dehydration into acrolein being considered a valorization route by itself, recent efforts have mainly focused on acrolein oxidation products: Acrylic acid [108,172,173] and different patents can be found in the literature on this topic [174-177], e.g., catalysts based on Mo-V-O systems demonstrate high yields (75\%) for acrylic acid production from glycerol [178].

The alcohol oxidation reaction catalyzed by noble metals has been studied since the 1990s, when supported Pt group metals were employed [2,179-181]. As an example, in 1993, Kimura et al. [182] reported the activity of supported Pt and Pt-Bi catalysts, observing that the reaction is favorable under $\mathrm{pH} 2-4$, controlling $\mathrm{Pt}$ lixiviation and dihydroxyacetone polymerization. The addition of Bi increased the reaction selectivity to dihydroxyacetone. On the contrary, Prati et al. [179] reported an increment of the initial reaction rate of around 4 times at $\mathrm{pH} 14$ with respect to the values at $\mathrm{pH} 2$, obtaining a glyceric+tartronic acids mixture with yields of around 47 and $58 \%$ for the $1 \% \mathrm{Au}-\mathrm{Pt} / \mathrm{C}$ and $5 \% \mathrm{Pt} / \mathrm{C}$ catalyst, associated with conversions of 80 and $88 \%$, respectively. Adding to this, Au alloys prevent Pt group oxygen poisoning. The reaction is commonly described in the literature under basic conditions, mainly due to the fact that alkaline media accelerates the reaction, improves the selectivity to $\mathrm{C} 3$ products, and prevents deactivation [183]. 


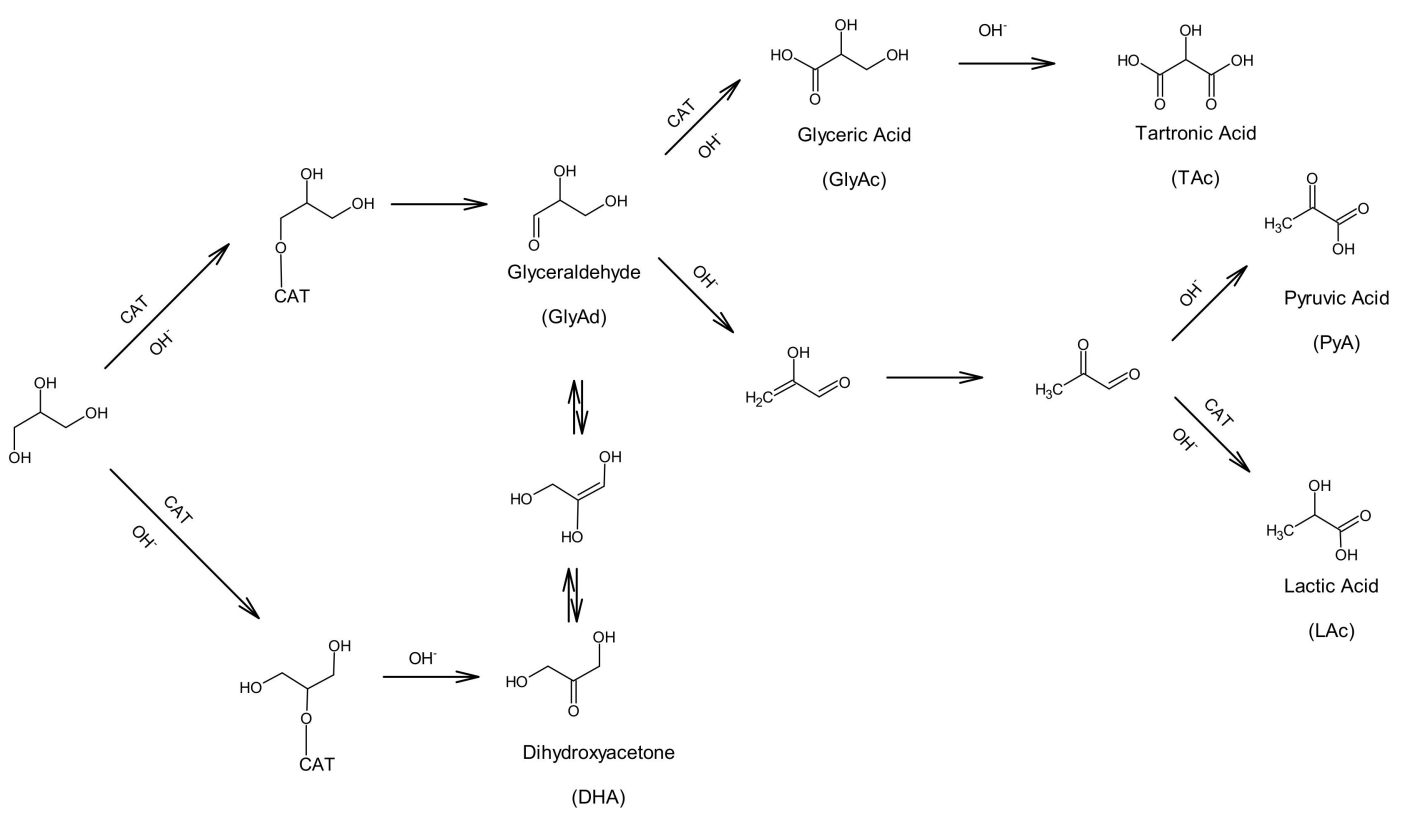

Figure 10. Different C3 products observed in glycerol selective oxidation under alkaline conditions.

Recent advances in the employment of noble metals as active phases, especially $\mathrm{Au}$ and $\mathrm{Pt}$, are focused on selective oxidation base-free and room condition reactions [29,184-187]. In this line, support properties may be key to achieving this objective through metal particle sintering prevention [188], as well as the establishment of metal synergies with superficial acid-base centers [189]. Special attention must be paid to polyoxomethalates, which have exhibited an interesting activity under mild conditions $\left(60^{\circ} \mathrm{C}\right)$, even with crude glycerol (Table 6), and could be supported as a catalyst modifier [190].

Table 6. Catalysts selected for glycerol oxidation.

\begin{tabular}{|c|c|c|c|c|}
\hline Catalyst & Reaction Conditions & $\begin{array}{c}\text { Glycerol } \\
\text { Conversion \% }\end{array}$ & $\begin{array}{l}\text { Main Product } \\
\text { (\% Yield) }\end{array}$ & Ref. \\
\hline $\mathrm{Au}-\mathrm{Nb}_{2} \mathrm{O}_{5}$ & $\begin{array}{c}\text { Glycerol }(0.23 \mathrm{~g}), \mathrm{NaOH}(0.20 \mathrm{~g}) \text {, catalyst } \\
(0.05 \mathrm{~g}) \text {, water }(25 \mathrm{~mL}), \text { pressure of oxygen } \\
(6 \mathrm{~atm}), 15 \mathrm{~h} .\end{array}$ & 80 & GlyAc (72) & [171] \\
\hline $\mathrm{Pt} / \mathrm{CeO}_{2}-\mathrm{ZrO}_{2}-\mathrm{Fe}_{2} \mathrm{O}_{3} / \mathrm{SBA}-16$ & $\begin{array}{c}1 \mathrm{wt} \% \text { glycerol aq. }(10 \mathrm{~mL}) \text {, catalyst }(0.3 \mathrm{~g}), \\
\quad 30^{\circ} \mathrm{C} \text { in an open-air system for } 4 \mathrm{~h} .\end{array}$ & 70.3 & GlyAc (28) & [191] \\
\hline 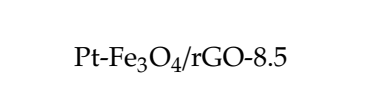 & $\begin{array}{c}\text { Glycerol (3 mmol), Pt/glycerol (molar ratio, } \\
\text { 1:1000), } \mathrm{H}_{2} \mathrm{O}(30 \mathrm{~mL}), \mathrm{O}_{2} \text { flow }(150 \mathrm{sccm}) \\
60^{\circ} \mathrm{C}, 2 \mathrm{~h} .\end{array}$ & 29.5 & GlyAd (14.8) & [192] \\
\hline $\mathrm{Au} / \mathrm{MgO} / \mathrm{TiO}_{2}$ & $\begin{aligned} \mathrm{T}= & 50^{\circ} \mathrm{C}, 0.3 \mathrm{M} \text { glycerol aq., } \mathrm{NaOH} / \text { glycerol } \\
& =4 \text { eqv., glycerol/gold ratio }=1000,1 \mathrm{~h}\end{aligned}$ & 100 & GlyAc (56) & [193] \\
\hline $\mathrm{PtCo} / \mathrm{Mg}_{3} \mathrm{Al}(\mathrm{OH})_{\mathrm{y}}\left(\mathrm{CO}_{3}\right)_{\mathrm{z}}$ & $\begin{array}{l}\text { Glycerol: } 0.3 \mathrm{M} \text { aq., } \mathrm{NaOH} / \text { glycerol molar } \\
\text { ratio: 2/1, volume: } 15 \mathrm{~mL} \text {, catalyst: } 0.05 \mathrm{~g} \text {, } \\
\text { T: } 100{ }^{\circ} \mathrm{C}, \mathrm{P}_{\mathrm{O} 2}: 0.5 \mathrm{MPa}, 6 \mathrm{~h}\end{array}$ & 96 & LA (64) & [194] \\
\hline $1 \mathrm{wt} \% \mathrm{Au} /$ bentonite & $\begin{array}{c}\mathrm{T}=90{ }^{\circ} \mathrm{C}, 50 \mathrm{~mL} \mathrm{NaOH} / \mathrm{glycerol}=8 \mathrm{~mol} \\
\text { ratio, } 0.25 \mathrm{~g} \text { catalyst, } 4 \mathrm{~h}\end{array}$ & 82 & LA (76.1) & [195] \\
\hline $\mathrm{AlPMo}_{12} \mathrm{O}_{40}$ & $\begin{array}{c}5.0 \mathrm{~mL} \text { of } 1.0 \mathrm{M} \text { glycerol aq., } 1 \mathrm{MPa} \mathrm{O}_{2} \\
4.0 \mathrm{mM} \text { catalyst, } 60^{\circ} \mathrm{C} \text { for } 5 \mathrm{~h}\end{array}$ & 98.6 & LA (96.1) & [190] \\
\hline $\mathrm{AlPMo}_{12} \mathrm{O}_{40}$ & $\begin{array}{l}5.0 \mathrm{~mL} \text { synthetic crude glycerol }(71 \% \mathrm{Gly}) \text { in } \\
\text { methanol, } 1 \mathrm{MPa} \mathrm{O}_{2}, 4.0 \mathrm{mM} \text { catalyst, } 60^{\circ} \mathrm{C} \\
\text { for } 5 \mathrm{~h}\end{array}$ & 92.1 & LA (86.8) & [190] \\
\hline $3 \% \mathrm{Pt} / \mathrm{HZSM}-5$ & $70^{\circ} \mathrm{C}, 4 \mathrm{~h}$, air flow $\left(60 \mathrm{~mL} \mathrm{~min}^{-1}\right)$ & 67.9 & GlyAc (30) & [196] \\
\hline $2.9 \mathrm{~V} 7.5 \mathrm{APO}(0.2)$ & $\begin{array}{c}10 \% \text { glycerol aq., } \mathrm{T}=350^{\circ} \mathrm{C}, 0.2 \mathrm{~g} \text { catalyst, } \\
\text { air flow } 1200 \mathrm{~mL} \mathrm{~h}^{-1} \text { and feed flow rate } \\
3.6 \mathrm{~mL} \mathrm{~h}^{-1}\end{array}$ & 98.3 & Methanol (83) & [197] \\
\hline $\mathrm{Pt}_{0.8} \mathrm{Ru}_{0.8} / \mathrm{MCM}-41$ & $\begin{array}{c}0.2 \text { catalyst, } 25 \mathrm{~mL} \text { aqueous solution of } \\
\text { glycerol }(0.22 \mathrm{M}) \text {, glycerol/Pt molar ratio } 700 \text {, } \\
\qquad 80^{\circ} \mathrm{C}, 1 \mathrm{MPa} \mathrm{O} \mathrm{O}_{2}, 12 \mathrm{~h}\end{array}$ & 78.2 & GlyAc (63) & [198] \\
\hline
\end{tabular}


Table 6. Cont.

\begin{tabular}{|c|c|c|c|c|}
\hline Catalyst & Reaction Conditions & $\begin{array}{c}\text { Glycerol } \\
\text { Conversion \% }\end{array}$ & $\begin{array}{l}\text { Main Product } \\
(\% \text { Yield })\end{array}$ & Ref. \\
\hline $\mathrm{AuPt} / \mathrm{N}-\mathrm{TiO}_{2}$ & $\begin{array}{c}0.3 \mathrm{M} \text { aqueous glycerol solution, } \\
\text { glycerol } / \mathrm{M}=500, \mathrm{~T}=100^{\circ} \mathrm{C}, \mathrm{p}_{\mathrm{O} 2}=3 \mathrm{~atm}, 6 \mathrm{~h}\end{array}$ & 92 & GlyAc (73) & [199] \\
\hline $\mathrm{VNb} / \mathrm{Al}_{2} \mathrm{O}_{3}$ & $\begin{array}{c}50 \mathrm{~mL} \mathrm{Min}^{-1} \text { of neutralized crude glycerol: } \\
\begin{array}{c}50 \% \mathrm{H}_{2} \mathrm{O}_{2} \\
\text { WHSV }\end{array}=0.5 \mathrm{~h}^{-1} \text { and } 2000^{\circ} \mathrm{C} \\
\mathrm{t}=15 \mathrm{~h} \text { measure }\end{array}$ & 100 & Formic acid (45) & [200] \\
\hline $\mathrm{AuPt} / \mathrm{TiO}_{2}-\mathrm{NC}$ & $\begin{array}{c}20 \mathrm{~mL}, 0.3 \mathrm{M} \text { glycerol, } 1.2 \mathrm{M} \mathrm{NaOH} ; 3 \text { bar } \mathrm{O}_{2} ; \\
110^{\circ} \mathrm{C} \text {; catalyst }(0.029 \mathrm{~g}), 7 \mathrm{~h}\end{array}$ & 99 & LA (82) & [201] \\
\hline
\end{tabular}

Another emerging option for performing room temperature oxidation processes is electrocatalysis due to its effective activity and selectivity to a specific compound, produced by tuning the structure of the electrocatalyst and/or the electrode potential [202-205]. Even though base addition is environmentally undesirable, in this process, whilst an inorganic base can act as an electrolyte for the reaction, other buffers can be applied [205]. As an active phase, different noble metals have been reported, but the design of catalysts based on other economic transition metals, stable in acid media, represents a challenge to overcome for their application [206].

\section{Production of Glycerol Carbonate}

Glycerol carbonate is a high value-added product with a high market price, which can be used in the synthesis of biopolymers, methylating agents, and methoxycarbonylating agents [24,207]. The production of glycerol carbonate from glycerol can be catalyzed by inorganic (commonly alkaline earth metal oxides and hydrotalcites) or organic (biocatalyst) compounds, for instance, Candida antarctica lipase B supported on Accurel MP1000 (CalBAcc) [208]. The reaction can be conducted in batch or continuous reactors [209]. Nowadays, there is a way to produce glycerol carbonate from fossil fuel, with propylene carbonate, in the presence of catalysts and small amounts of $\mathrm{Hg}$ [210]. However, the employment of $\mathrm{Hg}$ is not desirable from an environmental point of view and makes this route undesirable.

Glycerol carbonate from glycerol can be produced through several routes, which are commonly divided into two groups-indirect or direct routes-depending on the carbonate sources [211]; direct routes include carboxylation $\left(\mathrm{CO}_{2}\right)$ and oxidative carboxylation $\left(\mathrm{CO}+\mathrm{O}_{2}\right)$, whilst indirect routes can be transesterification with di-carbonates or alkyl carbonates, glycerolysis-urea [212], and phosgenation. It is important to highlight the possibility to use $\mathrm{CO}_{2}$ as a carbonate source, either because it helps with the valorization of other large by-products or presents the possibility of some mitigation and control of $\mathrm{CO}_{2}$ emissions. Nowadays, the $\mathrm{CO}_{2}$ problem is receiving a tremendous amount of attention from society, governments, and industries. However, the abovementioned process is less effective than others, mainly due to thermodynamic limitations, for instance, a typical yield is around $<10 \%$, against $>80 \%$ with indirect routes.

Indirect routes normally lead to a higher yield of glycerol carbonate, where the catalysts play a key role. Starting with glycerol transesterification, some reviews have summarized the types of catalysts $[207,211]$, which are very similar to other transesterification processes, including $\mathrm{K}_{2} \mathrm{CO}_{3}$, $\mathrm{CaO}, \mathrm{MgO}$ [213], $\mathrm{ZnO}$, and $\mathrm{H}_{2} \mathrm{SO}_{4}$. Several types of hydrotalcite have been tested, such as $\mathrm{Al} / \mathrm{Mg}$, $\mathrm{Al} / \mathrm{Li}, \mathrm{Al} / \mathrm{Ca}, \mathrm{Mg} / \mathrm{Al}$, etc. [214]. Some authors have focused on producing a catalyst from residues and waste. For instance, K. Mohanty used waste red mud from the aluminum industry to synthesize a catalyst [215]. The waste was calcined at temperatures between 400 and $800{ }^{\circ} \mathrm{C}$. The final product was a mixture of metal oxides such as $\mathrm{Fe}_{2} \mathrm{O}_{3}, \mathrm{Al}(\mathrm{OH})_{3}, \mathrm{CaCO}_{3}, \mathrm{CaSiO}_{4}, \mathrm{SiO}_{2}, \mathrm{NaAlO}_{2}, \mathrm{Ca}_{2} \mathrm{SiO}_{4}$, and $\mathrm{Na}_{8} \mathrm{Al}_{6}\left(\mathrm{SiO}_{4}\right)_{6} \mathrm{Cl}_{2}$. The complexity of the resulting catalyst calcined at $500{ }^{\circ} \mathrm{C}$ gave a good balance between basic and acid sites, resulting in the highest catalytic activity. In a similar approach, using residues as catalysts, Wang Song et al. [216] tested activated carbon obtained from corncob residue as a catalyst in the transesterification of glycerol with dimethyl carbonate, achieving conversions of over 
$95 \%$ with a selectivity greater than $90 \%$. A recent publication by Anusorn Seubsai et al. evidenced an improvement of the catalytic activity of sodium aluminate doped with $\mathrm{CaO}$ using glycerol in the synthesis as a template [217,218]. The yield for glycerol carbonate increased from 26 to $40 \%$ when $45 \mathrm{wt} \%$ of glycerol was used in the synthesis of the catalyst. A larger amount of template eventually led to a detriment in the catalytic activity. Some authors have employed crystalline perovskite to obtain glycidol via the decarboxylation of glycerol carbonate in one pot [219]. For the synthesis of GC, they have used glycerol and di-methylcarbonate. One of the main problems in this reaction is the low miscibility between glycerol and some carbonates, for instance, di-methylcarbonate, which can be avoided using organic solvents, methanol, tert-butanol, etc.

Another important indirect route uses urea as the carbonate source. Marcio J. da Silva et al. recently reported $\mathrm{Sn}(\mathrm{OH})_{2}$ as a catalyst synthesized in situ from $\mathrm{SnCl}_{2}, \mathrm{SnF}_{2}$, and $\mathrm{SnBr}_{2}$ and urea [220]. MohdHasbi Ab. Rahim et al. used waste boiler ash as a catalyst. Analogously, Verraboina Subbaramaiah used residues as a potential catalyst, and a rice husk residue loaded with $10 \mathrm{wt} \%$ Ce resulted in a $92 \%$ yield for glycerol carbonate under $98 \%$ glycerol conversion under optimum conditions [221]. Benjaram M. Reddy et al. reported nanostructured $\mathrm{MoO}_{3}$ and $\mathrm{WO}_{3}$ promoted with $\mathrm{SnO}_{2}$ as an efficient catalyst for carbonate production with urea in solvent-free conditions. The $\mathrm{SnO}_{2}$ nanoparticles supported on $\mathrm{MoO}_{3}$ and $\mathrm{WO}_{3}$ exhibited a high selectivity to glycerol carbonate, with a value of over $90 \%$, with glycerol conversion greater than $60 \%$, while the selectivity of un-supported $\mathrm{SnO}_{2}$ nanoparticles was less than $80 \%$ [222].

Regarding direct routes, the direct carbonylation of glycerol with $\mathrm{CO}_{2}$ can be conducted with a heterogeneous or homogeneous catalyst. Lui et al. utilized $\mathrm{CeO}_{2}$ nanoparticles synthetized through different methodologies in the presence of several dehydrating agents and solvents in the direct carbonylation of glycerol with $\mathrm{CO}_{2}$ [223]. The amount of 2-cyanopyridine and the calcination process of the catalyst resulted in crucial parameters for yielding GC. Under optimal conditions of $150{ }^{\circ} \mathrm{C}$, $4 \mathrm{MPa}$, and $5 \mathrm{~h}$, the yield was $78 \%$. Recent studies have evidenced the promising strategy of applying a photo-thermal synergistic catalyst for glycerol conversion to glycerol carbonate with $\mathrm{CO}_{2}$ [224]. Dehua $\mathrm{He}$ et al. synthesized an $\mathrm{Au} / \mathrm{ZnWO}_{4}-\mathrm{ZnO}$ catalyst with different loadings of $\mathrm{Au}$. As a result, $\mathrm{ZnWO}_{4}-\mathrm{ZnO}$ was active itself, giving a $6 \%$ yield for GC, while $2 \mathrm{wt} \%$ Au loading increased the yield to over $8 \%$ under visible light.

\section{Production of Solketal or Acetalization of Glycerol}

In general, solketal, as one of the common glycerol valorization routes described in the literature, is a product which can be used as a solvent [225]. Several reviews were published during the 2010s (e.g., in 2012 [226], 2016 [227], 2018 [228], and 2019 [229]). The latter study categorizes three generations (Gen) of the acetalization of glycerol: 1st Gen., which englobes homogeneous catalysts and solvents, with HCL, $\mathrm{Na}_{2} \mathrm{SO}_{4}+\mathrm{HCl}$, and petroleum ether as solvents; 2nd Gen., which is focused on heterogeneous catalysts and solvents, with Amberlyst-36 (2007) [230] and Zeolites MMT-K10 solvents as dichloromethane, toluene, benzene, etc. Nanda et al., in 2014, published a study on several catalysts used in glycerol conversion to solketal using ethanol as a solvent [231]; and, finally, the 3rd Gen., which includes heterogeneous catalysts in batch or continuous flow, without solvent [232]. Acetone is normally added at a higher ratio than stoichiometric, in order to ensure high-yield production. However, the literature does not clarify if it also favors the reaction as a solvent. Some authors have reported complete conversion. M.S. Khayoom and B.H. Hameed reported, in 2013, a 98\% conversion using $5 \mathrm{wt} \% \mathrm{Ni}$ supported on activated carbon, achieving around a $73 \%$ selectivity to solketal. The experimental conditions were $5 \mathrm{~g}$ of glycerol for $2 \mathrm{~g}$ of catalyst, a molar ratio of glycerol:acetone of $1: 8,45^{\circ} \mathrm{C}$, and $3 \mathrm{~h}$ of reaction. One paper recently published in the Catalyst journal by Fernandez P. et al. described the production of sulfonated carbon from cellulose and glucose and its performances in solketal production at room temperature [233]. Using a molar ratio of glycerol:acetone of 1:7 and a catalyst concentration of $1 \%$ weight of glycerol, the authors reported the same yield range for solketal as described in the literature [234]. Recently, Marcio Jose da Silva et al. published a study on the production of solketal 
from glycerol and acetone using $\mathrm{Sn}(\mathrm{II})$-exchanged silicotungstic acid salt $\left(\mathrm{Sn}_{2} \mathrm{SiW}_{12} \mathrm{O}_{40}\right)$, achieving a conversion value of more than $99 \%$ and selectivities of up to $97 \%$ [235], using glycerol:acetone molar ratios of 1:12 and larger. If the amount of acetone decreases, the conversion decreases as well, and is around $70 \%$ for a molar ratio of 1:4. In our opinion, despite the fact that acetone's role as a solvent has not yet been demonstrated, its double role as a reagent and solvent cannot be discarded.

The main drawback of the acetalization reaction is the production of water, which causes the opposite reaction (reversible process) and deactivation of the catalyst. In the literature, there are some scientific works focused on this problem, which they solve by using water-tolerant catalysts, such as zeolites, mesoporous silicas, heteropolyacid, metals, or polymer-based catalysts. The perspective on this type of reaction should be to develop catalyst water-resistant reaction media or systems able to remove or separate water to maximize the yields.

\section{Emergent Valorization Routes}

With glycerol valorization having been a research topic since the 1990's, many routes have been proposed, some of which have been widely studied and developed and others which did not have the same impact or have recently been reported. As glycerol is expected to be produced on a large scale and with different characteristics, every valorization route might be a potential solution. The lack of transcendence in scientific literature is probably due to several important inconveniences, not being easily scalable to industrial processes, and because the approach was recently published, etc. Research aimed at finding solutions and the continuous development of these emergent technologies should become a trend in glycerol valorization research.

\subsection{Emergent Strategy Developed to Obtain $\mathrm{H}_{2}, \mathrm{CO}$, and Syngas}

This strategy uses glycerol as a sacrifice molecule, such as reforming, APR, or dry reforming (described in Section 3.3. Glycerol Reforming). Considering the stoichiometric reaction, one molecule of glycerol can produce three molecules of $\mathrm{CO}$ and four of $\mathrm{H}_{2}$. The reactions, catalyst, and processes developed in this strategy are not specific for glycerol, as many other molecules can be used. The main disadvantage of these technologies is $\mathrm{CO}_{2}$ production as a by-product, and thus the atomic efficiency may vary, depending on the yield of the process. As glycerol valorization might be a large-scale process, and nowadays $\mathrm{CO}_{2}$ is considered to be a pollutant, any industry based on these technologies might have a large carbon footprint and the associated negative environmental impact. Within this approach, some technologies have been widely studied; however, the low yield and the complicated processes and selectivity are yet to be a matter of research.

\subsubsection{Photoreforming}

When clean energies are considered, $\mathrm{H}_{2}$ is one of the most representative molecules, so many authors have focused their efforts on producing it using clean energies, such as sunlight. This process is called the photoproduction of $\mathrm{H}_{2}$ or photoreforming, and the results can be found in different publications and reviews [236-241]. Nowadays, the production of energy from renewable sources is quite well-developed, as in the case of solar plants, eolic plants, etc. Therefore, in many of the abovementioned technologies, clean energy can be used. Indeed, the photoproduction of $\mathrm{H}_{2}$ present some advantages, such as low-cost reactors, no need for energy input installation, easy installation in remote locations, etc. The main drawbacks are the low yield and the fact that some $\mathrm{CO}_{2}$ is produced, as in thermal reforming. Many authors argue that this $\mathrm{CO}_{2}$ produced should not count towards the carbon footprint of the processes, as the feed comes from biomass and this biomass can adsorb the $\mathrm{CO}_{2}$ from the atmosphere in a relatively short period of time. There is a large debate about whether $\mathrm{CO}_{2}$ produced from biomass should be counted in the carbon footprint. As far as we are concerned, it should be considered, because the whole process requires an energy input in many steps, the transportation of feedstock, the fabrication of facilities, etc. In any case, $\mathrm{CO}_{2}$ is a by-product, detrimental for the cost of the process. 
Kawai and Sakata were two of the first authors who reported the production of $\mathrm{H}_{2}$ from several organic compounds in 1979 [242]. Today, the catalysts employed are composites of two, three, or even more materials, with at least one being a semiconductor. This semiconductor must be used for harvesting the light, obtaining a photon that excites one electron in the semiconductor from its valence band to its conduction band. Among the several semiconductors that have been used, including metal oxides, oxynitride, sulfides, carbides, etc., $\mathrm{TiO}_{2}$ is one of the most frequently employed ones [243]. Then, a cocatalyst must be incorporated, with the main function of facilitating electron transfer from the semiconductor to the $\mathrm{H}^{+}$. The first cocatalysts tested were noble metals, $\mathrm{Pt}, \mathrm{Ru}$, and $\mathrm{Au}$, and many research papers were published from 2017 to 2018 [238,244]. More recent publications using noble metals as cocatalysts are focused on either developing a better semiconductor $[239,245,246]$ or developing a new synthetic method for catalyst preparation [247].

As noble metals are expensive, there are many research studies and publications focused on their substitution, testing other transition metals, such as $\mathrm{Cu}, \mathrm{Co}$ [248], $\mathrm{Ni}$ [249], Fe, etc. One of the most studied is $\mathrm{Cu}_{2} \mathrm{O}$, forming nanoparticles deposited on $\mathrm{TiO}_{2}[237,250]$, or $\mathrm{TiO}_{2}$ nanorods with $\mathrm{Cu}_{2} \mathrm{O}$ [251]. W. T. Chen et al. compared $0.5 \mathrm{wt} \% \mathrm{Ni}$ with $2 \mathrm{wt} \%$ Au supported on P25. The activity significantly changed with the alcohol concentration for Ni-based catalysts, from 26 to $10 \mathrm{mmol} \mathrm{g}^{-1} \mathrm{~h}^{-1}$ using a 10 and $80 \mathrm{vol} \%$ of alcohol, respectively. In the case of an Au-based catalyst, the variation was not as high, ranging from 30.3 to 17.3 . Using a $10 \mathrm{vol} \%$ of glycerol, the activity of both catalysts was similar [252]. The main problem of $\mathrm{Cu}$ and other non-noble metals is their lack of stability due to the photocorrosion process. When a photocatalyst suffers from photocorrosion, the generated electron reduces the oxide to metal and, after some time under the reaction condition, the catalyst loses activity and requires a regeneration treatment. There is still some controversy in the literature as to whether the cocatalyst is the metal or the oxidized forms.

Some of the latest research papers on the topic focus on a single atom for photocatalytic reforming [253]. This research approach reduces the amount of metal in the final catalyst, from a typical $1-5 \mathrm{wt} \%$ loading for nanoparticles deposited to 0.1 to $0.5 \mathrm{wt} \%$, and therefore, the final cost of the catalyst, opening a new era for noble metal catalysts. The synthetic methods are different to conventional methods, such as deposition, precipitation, and impregnation. Normally, the metal is incorporated during the synthesis of the support or loaded as ion exchange, in a chemical reaction. The development of this strategy is expected to have a large scientific impact in the next decade. Further uses could be promoting $\mathrm{H}_{2}$ production from biomass if glycerol is added [250], which would allow glycerol to be applied in the photoreforming of many other chemical compounds. During photoreforming or a photoreaction, many secondary reactions take place, and some of them are detrimental for the yield. Hanquing et al. reported the photocatalytic reduction of bicarbonate to formic acid using glycerol for secondary oxidation reactions [254].

\subsubsection{Catalytic Transfer Hydrogenation (CTH)}

The production of $\mathrm{H}_{2}$ has gained a huge amount of interest in the last decades, as it is a potential clean energy fuel [57]. In this route, there are several technologies employed, such as gasification, steam reforming [211,255], dry reforming [100,256], pyrolysis, and aqueous phase reforming [257] (see Section 3.3). The drawbacks of reforming are the drastic reaction conditions (atmospheric pressure and temperature $<800{ }^{\circ} \mathrm{C}$ ) and many side reactions and the production of $\mathrm{CO}_{2}$. As an alternative, catalytic transfer hydrogenation (CTH) can be conducted at much milder conditions $\left(100^{\circ} \mathrm{C}\right.$ and $\left.1 \mathrm{~atm}\right)$. $\mathrm{CTH}$ can be divided into two main types: Internal $\mathrm{H}$ transfer, implying that $\mathrm{H}_{2}$ is produced and some parts of the molecules are sacrificed (APR with $\mathrm{H}_{2}$ generation in situ), and external transfer, where $\mathrm{H}$ is transferred to the acceptor molecule. Some recent reviews can be found in the literature $[258,259]$. In the first case, where the $\mathrm{H}_{2}$ is generated from the same feedstock, two possible approaches are suggested: A sequential process in tandem or both processes in one pot reaction. Xin Jin reported, in 2018, the theoretical product distribution of both approaches, being, for a tandem process, $82-87 \%$ of liquids glycols and $13-18 \%$ gas phase, mainly $\mathrm{CO}_{2}$. For a one pot process, $33-50 \%$ glycols and $50-67 \%$ lactate 
were obtained [259]. In CTH, two processes must occur-dehydrogenation and hydrogenolysis—in the same pot or at similar rates, so the challenge is to design the catalyst to combine or control both functions. In general, noble metals $\mathrm{Pt}, \mathrm{Pd}$, and $\mathrm{Ru}$ and non-noble $\mathrm{Co}$ and $\mathrm{Ni}$ have been described as effective catalysts for APR. If a promoter is added, such as $\mathrm{Zn}$ or $\mathrm{Sn}$, the selectivity to $\mathrm{H}_{2}$ can be improved. Appropriate catalysts for hydrogenolysis are metallic parts supported on acid or basic supports, depending on the desired product (hydrogenolysis and reduction processes). One example of CTH was reported by Luque et al., who compared different $\mathrm{H}$ donating solvents, including glycerol, tetralin, formic acid, and isopropanol, for the de-polymerization of lignin [260]. The catalyst was Ni $10 \mathrm{wt} \%$ supported on Al-SBA15, and when used for a catalytic test of the weight ratio of catalyst:liquid lignin of 1:1, glycerol resulted in the smallest proportion of residual lignin and was thus the most efficient molecule to be used with this type of catalyst for the CTH process.

\subsection{Production of Valuable Chemicals}

On the other hand, the whole molecule or a large part of it can be used to produce valuable chemicals, such as aldehydes, ketones, glycerol carbonate, glycidol, epichlorohydrin, etc. The processes developed in this strategy are more specific for glycerol molecules, as they are part of the final product. The reactions and catalyst can perhaps be used with other molecules, but the final product will be different to that produced from glycerol. This strategy has the advantage of having a large atomic efficiency, and moreover, the most common by-products (if any) are environmentally friendly, such as $\mathrm{H}_{2} \mathrm{O}, \mathrm{O}_{2}$, etc. Pollutants such as $\mathrm{CO}_{2}$ or $\mathrm{CH}_{4}$ might be produced; however, the yield of these molecules is usually negligible compared with reforming products. The process and technologies within this strategy based on all/a large part of glycerol molecule usage normally lead to chemical products with two or more $\mathrm{C}$ atoms. The most frequently described processes mentioned before, such as hydrogenolysis, oxidation, and esterification, are some examples. Nevertheless, some other technologies based on heterogeneous catalysis have been reported in the literature and are summarized in Table 7. Note that, apart from these processes, other possibilities can be found based on homogeneous catalysis, such as the synthesis of amines or their application as a protector of functional groups in organic synthesis [261]. However, all of these alternatives are outside the scope of the present work. Recently, special interest has been paid to the production of glycerol ether, which is considered a valuable additive in gasolines. The reaction implies the condensation between glycerol and tert-butyl alcohol to obtain mono, di, and tri ethers, with the last two being used as gasoline additives. The possibility to produce polycarbonates from crude glycerol and $\mathrm{CO}_{2}$ should be highlighted [262], which is a process that can upgrade two by-products produced on a large scale.

Table 7. Summary of some molecules produced from glycerol through heterogeneous catalysts.

\begin{tabular}{ccc}
\hline Molecule & Use as & Ref \\
\hline Tert-butyl ethers & Gasoline additives & {$[263]$} \\
Orthoesters & Platform molecule & {$[264]$} \\
Alkyl amines & Pharmaceutical, agrochemicals, paints, etc. & {$[265,266]$} \\
Oxazoline & Biomedical polymers & {$[267]$} \\
Allyl alcohol & Pesticide & {$[268]$} \\
Polyglycerol succinate & Polymer production & {$[269]$} \\
Hyperbranched polyesters & Polymers & {$[270]$} \\
Di/tri-glycerol & Polymer production & {$[271]$} \\
Divinylglycol & Polymer production & {$[272]$} \\
Eutectic solvents & Solvents & {$[273,274]$} \\
Polycarbonates & Polymers & {$[262]$} \\
\hline
\end{tabular}

Among all these possibilities, some related to fuel or refineries are briefly discussed below. 


\subsubsection{Conversion of Glycerol to Alkyl-Aromatics (Gasoline)}

One of the first articles in the field was published by Trung. Q in 2010 [275]. Since then, the conversion of methanol to gasoline has been widely studied, with zeolites being the most active catalyst. Trung et al. studied the conversion of glycerol over acidic zeolites ZSM-5, zeolite $Y$, mordenite (MOR), and ZSM22. All zeolites were converted to a proton form by calcination and the $\mathrm{Na}^{+}$ion in MOR was replaced with $\mathrm{NH}^{4+}$ to achieve a similar acidity to the rest of the zeolites $(\mathrm{Al} / \mathrm{Si}=45)$. The catalyst was placed in a fixed bed continuous flow reactor and glycerol was fed using $\mathrm{H}_{2}$ as a carrier at a molar ratio of 15:1 $\left(\mathrm{H}_{2} /\right.$ glycerol). Two types of liquid products were produced: A hydrocarbon phase with aromatics and an aqueous phase with oxygenates [276]. The aromatic part might be considered as an alternative fuel or gasoline additive. Typical zeolites have narrow and rigid micropores, which hinder the mass transportation of large molecules, such as aromatics produced in this type of process. Feng-Sohou et al. revised the alternative trend of expanding the pore size of acid zeolite materials [277]. There are several approaches to expanding the pores, including after synthesis and before synthesis, and in general, both lead to active catalysts for glycerol conversion to alkyl-aromatic. One problem of these materials is the deactivation by coke deposition [278]. Dinesh Kumar et al. tested an aluminosilicate mesoporous material-KIT6-loaded with Pd between 0.5 and $1.5 \mathrm{wt} \%$ and $\mathrm{Al}$ maintaining a silica to alumina ratio of 80 [279]. Pd lightly promoted the conversion, with a larger production of hydrocarbon fractions and with an increment of its calorific value, from 31 to $36 \mathrm{MJ} / \mathrm{kg}$, showing the importance of Pd loading. However, the catalyst displayed deactivation due to coke formation on the catalyst surface. Hero J. Heeres recently reported the regeneration of catalyst type H-ZSM-5 through an in-situ oxidative regeneration process [280]. After the fifth regeneration, the catalyst lost about 105 of its surface area and $90 \%$ of the Bronsted acid sites, indicating an activity decay close to $50 \%$. The main challenge in this route is the deactivation of the catalyst, which is a topic that should be focused on in research in the following years.

\subsubsection{Production of Activated Carbon from Glycerol}

Glycerol produced in biodiesel industries has a low metallic content, 2-3\% salts (primarily sodium and potassium), and 2-3\% other impurities [281]. If compared with other activated carbon sources, it has the advantage of producing low metal content activated carbon. If high-purity glycerol is used, then the subsequent activated carbon is metal-free. However, the production cost increases dramatically. One of the first papers was published by Bethala L.A. in 2009 [282]. The activated carbon was produced by partial carbonization and sulfonation using a glycerol/ $\mathrm{H}_{2} \mathrm{SO}_{4}$ weight ratio of 1:4. The temperature was increased at $10{ }^{\circ} \mathrm{C} \cdot \mathrm{min}^{-1}$ till $180{ }^{\circ} \mathrm{C}$ and held for $20 \mathrm{~min}$. After that, the obtained product was cooled down and then washed with water until reaching a neutral $\mathrm{pH}$ of the wash water. The authors described a yield of up to $50 \%$ of the glycerol weight used. The final solid was insoluble in methanol, ethanol, chloroform, benzene, and water. The main characteristics were a low surface area $\left(\sim 1 \mathrm{~m}^{2} \mathrm{~g}^{-1}\right)$ and a high acidity due to sulphonated surface groups. These materials can be used as catalysts for glycerol condensation, glycerol purification, etc., so the main advantage is the possibility of one industry producing its own catalyst from the same raw material. Later on, the product can be calcined under $\mathrm{N}_{2}$ flow at $800{ }^{\circ} \mathrm{C}$, in order to gain stability, $50 \mathrm{wt} \%$ loss up to $800{ }^{\circ} \mathrm{C}$, and a surface area of around $10 \mathrm{~m}^{2} \mathrm{~g}^{-1}$ [283]. On the other hand, the ash content can reach $>1 \%$. As with any other char, it can be further activated by exposure to an oxidizing atmosphere and temperatures. Using air and a temperature of up to $400{ }^{\circ} \mathrm{C}$ can increase the microporosity and surface area up to $600 \mathrm{~m}^{2} \mathrm{~g}^{-1}$. By using steam or $\mathrm{CO}_{2}$, the activation temperature can be increased up to $900{ }^{\circ} \mathrm{C}$ [284], increasing the surface area to over $2000 \mathrm{~m}^{2} \mathrm{~g}^{-1}$ and decreasing the yield below $20 \mathrm{wt} \%$. More recently, in 2019, CS Estes reported a synthetic method for highly functionalized carbon nanoparticles [285]. The method requires $\mathrm{H}_{2} \mathrm{SO}_{4}$ at a high mass ratio (15.2:1) and the reaction temperature must be set before reagent addition. The speed of reagent addition was $1 \mathrm{~mL} \mathrm{~min}{ }^{-1}$. Miguel a Madeiro reported the preparation of magnetic carbon from glycerol [286]. Novel preparations of activated carbon have been applied, for instance, microwave pyrolysis, demonstrating the potential 
of this fast method [287], or ultrasonic spray, leading to nitrogen-doped porous $\mathrm{Fe} / \mathrm{C}$ composites for chromium removal in water [288]. Activated carbon produced form glycerol has been successfully tested for Ni (II) removal [289] and as a supercapacitor [290].

\subsection{Strategies of Glycerol Application}

Many researchers have been working on catalytic valorization for such a long time that one promising strategy for glycerol valorization is being forgotten: The direct use of glycerol, without any chemical transformation. This strategy is missed in most of the reviews on glycerol valorization. Nowadays, glycerol is widely used in cosmetics, inks, lubricants, antifreeze, drugs, toothpaste, moisturizers, and as a solvent and food additive (E-422), etc. In this valorization strategy, the research work focusses on searching for and testing glycerol molecules in new applications or processes, taking into account the properties of the glycerol molecule and its reactivity and/or interaction with the surrounding media. Glycerol has remarkable properties, such as viscosity, lubricity, etc., and it also has the advantage of being a biodegradable molecule, so it can replace non-biodegradable molecules, leading to a positive environmental impact. In this sense, glycerol has been applied as an additive in industrial processes or products with a large carbon footprint. For instance, E. Silva Santos et al. used glycerol as an additive in emulsified marine diesel [291]. The authors reported an improvement of the lubricity and water reduction when a glycerol solution was added up to $15 \%$. Additionally, glycerol has been applied as an additive for bitumen [292,293], exhibiting acceptable and interesting properties as a surfactant in this field, and decreasing the carbon footprint of the final product. Despite the fact that the direct use of glycerol is not the topic of this review, we have considered it, as it is worth mentioning some contributions reporting the benefit of using glycerol for template molecules during the synthesis of catalysts. These studies imply both a direct use of glycerol and research on catalysts, reporting some interesting benefits of its usage as an additive for catalyst synthesis, for stabilizing and controlling the particle size [294], as a solvent in the synthesis of catalysts [295], and as a reductant agent for Au nanoparticle synthesis [296-298].

\section{Conclusions}

Despite the rise in biodiesel production, and glycerol as a consequence, its production is expected to stabilize in the following years due to the emergence of second and third generation biofuels. Consequently, glycerol production can be maintained over time while operating biorefineries. This supposes a constant source of glycerol that is unable to be assimilated by current markets and opens the possibility for the development and implementation of new industrial processes.

All in all, perspectives on the valorization of glycerol will depend on the economy, global demand, law, and environmental impact. Concerning the latter, the atom efficiency might play a key role. Therefore, research should aim to avoid or minimize by-products, with $\mathrm{CO}_{2}$ being one of the most worrying ones, for strategies related to energy obtention. This trend can already be seen in the literature, especially in reforming with the introduction of combined process of $\mathrm{CO}_{2}$ separation and purification for later uses or the market, in which effective and low-cost processes/materials for $\mathrm{CO}_{2}$ separation are needed. The valorization of globally produced glycerol will pass through several strategies, and to the authors, nowadays, all strategies on research phases count, whatever the prediction of glycerol consumption, in a large-, moderate-, or small-scale process. Attention should be paid to strategies that imply the valorization of several by-products, where the combination of glycerol with $\mathrm{CO}_{2}$ would help in global climate change. The next step for existing strategies and processes might be to move toward using crude glycerol as a product, which can facilitate cost-effective industrial implementation.

Regarding catalysts applied in glycerol valorization, the perspectives are changing in the direction of producing cheaper, more stable, and more efficient catalysts. The obtention of catalysts from residues or other industries' by-products is a promising route with a high potential for being cost effective. In general, processes based on $\mathrm{C}-\mathrm{C}$ and $\mathrm{C}-\mathrm{H}$ rupture tend to learn towards the substitution of noble metal nanoparticles with $\mathrm{Ni}-, \mathrm{Cu}_{-}, \mathrm{Fe}-$, and carbon-based catalysts. In the case of $\mathrm{C}-\mathrm{O}$ and 
$\mathrm{O}-\mathrm{H}$, new acid materials, such as expanded zeolites, alloys, or modified activated carbon (that might be produced from glycerol) loaded with transition metals, seem to represent the next generation for researchers. The recently developed single atom catalyst might have a large impact on glycerol valorization, as it might reduce the cost of noble metal-based catalysts. The main conclusions of the present review are as follows.

Concerning the reforming of glycerol to obtain $\mathrm{H}_{2}$, glycerol steam reforming is the most efficient technique, being highly developed in industry due to its easy adaptation and implementation in preexisting facilities. Therefore, there has been thorough research on this subject for years, with the use of membrane reactors representing a promising technique. However, alternatives such as dry reforming and aqueous phase reforming might gain attention due to their environmentally friendly nature. The main disadvantages of these strategies, such as the excessive deposition of coke, production costs, and effective catalysts, should lead the research. Regarding catalysts, more selective and especially stable materials against coke deposition will be a priority in future research in this field.

In terms of glycerol reduction processes, 1,2-PDO production via hydrogenolysis has demonstrated that it is a viable process for industrial applications, depending on markets. Catalysts based on $\mathrm{Cu}$ as an active phase can actively conduct glycerol hydrogenolysis to produce 1,2-PDO, but are not good enough to produce monoalcohols, leading to high 1,2-PDO yields. Regarding 1,3-PDO, there is not a clear route for achieving a high reaction selectivity (maximum yield of around $60 \%$ for $\mathrm{Pt}-\mathrm{WO}_{\mathrm{x}}$ catalysts) and future advances in this field are needed. Special attention must be paid to emerging technologies, such as single atom catalysts or single atom alloys, which could provide interesting results in 1,3-PDO production.

Glycerol oxidation is by far the most studied valorization route. Benefits such as the possibility of crude glycerol employment, reactions at room conditions, the possibility of open flask systems, and the obtention of valuable monomers for the polymer industry have made the reaction quite attractive. Nevertheless, nearly total conversions are usually reported under basic conditions at the cost of selectivity, which is the point where the research is focused, in an attempt to carry out reactions in acidic or neutral media. Future research in the electro-oxidation field would guide reaction selectivity to a specific product and can be performed under room or mild conditions. However, catalyst deactivation and stability must be improved.

Emergent valorization routes have the potential to become a real industrial option, especially those which focus on chemical or fuel production. They are in an early/middle stage of development, so intensive research is needed on each route. In a general way, efficient processes still need to be developed, as well as catalysts able to achieve a high yield of the desired product and ensure stability over time.

Author Contributions: Conceptualization, M.C., S.N.-D., V.M., and J.M.E.; investigation, M.C., S.N.-D., V.M., and J.M.E.; resources, S.N.-D. and J.M.E.; writing—original draft preparation, M.C., S.N.-D., and V.M.; writing-review and editing, S.N.-D. and M.C.; visualization, J.M.E.; supervision, S.N.-D. and V.M.; project administration, J.M.E.; funding acquisition, J.M.E. and V.M. All authors have read and agreed to the published version of the manuscript.

Funding: This research was funded by JUNTA DE EXTREMADURA and FEDER, grant numbers GR18150, IB18028, and TA18037.

Acknowledgments: The authors would like to thank the Junta de Extremadura and FEDER “Fondos Europeos de Desarrollo Regional" for the financial support.

Conflicts of Interest: The authors declare no conflict of interest.

\section{References}

1. Rodrigues, A.; Bordado, J.C.; Dos Santos, R.G. Upgrading the Glycerol from Biodiesel Production as a Source of Energy Carriers and Chemicals-A Technological Review for Three Chemical Pathways. Energies 2017, 10, 1817. [CrossRef] 
2. Pagliaro, M.; Rossi, M. The Future of Glycerol, 2nd ed.; Clark, J.H., Kraus, G.A., Eds.; Green Chemistry Series; Royal Society of Chemistry: Cambridge, UK, 2010; ISBN 978-1-84973-046-4.

3. Bagnato, G.; Iulianelli, A.; Sanna, A.; Basile, A. Glycerol Production and Transformation: A Critical Review with Particular Emphasis on Glycerol Reforming Reaction for Producing Hydrogen in Conventional and Membrane Reactors. Membranes 2017, 7, 17. [CrossRef]

4. Semkiv, M.V.; Ruchala, J.; Dmytruk, K.V.; Sibirny, A.A. 100 Years Later, What Is New in Glycerol Bioproduction? Trends Biotechnol. 2020, 38, 907-916. [CrossRef] [PubMed]

5. Singh, D.; Sharma, D.; Soni, S.; Sharma, S.; Sharma, P.K.; Jhalani, A. A review on feedstocks, production processes, and yield for different generations of biodiesel. Fuel 2020, 262, 116553. [CrossRef]

6. Callegari, A.; Bolognesi, S.; Cecconet, D.; Capodaglio, A.G. Production technologies, current role, and future prospects of biofuels feedstocks: A state-of-the-art review. Crit. Rev. Environ. Sci. Technol. 2019, 50, 384-436. [CrossRef]

7. Clark, J.H.; Farmer, T.J.; Hunt, A.J.; Sherwood, J. Opportunities for Bio-Based Solvents Created as Petrochemical and Fuel Products Transition towards Renewable Resources. Int. J. Mol. Sci. 2015, 16, 17101-17159. [CrossRef] [PubMed]

8. Chandel, A.K.; Garlapati, V.K.; Kumar, S.P.J.; Hans, M.; Singh, A.K. The role of renewable chemicals and biofuels in building a bioeconomy. Biofuels Bioprod. Biorefin. 2020, 14, 830-844. [CrossRef]

9. Sharma, B.; Larroche, C.; Dussap, C.-G. Comprehensive assessment of 2G bioethanol production. Bioresour. Technol. 2020, 313, 123630. [CrossRef] [PubMed]

10. Kargbo, H.; Harris, J.S.; Phan, A.N. “Drop-in" fuel production from biomass: Critical review on techno-economic feasibility and sustainability. Renew. Sustain. Energy Rev. 2021, 135, 110168. [CrossRef]

11. Dedes, G.; Karnaouri, A.; Topakas, E. Novel Routes in Transformation of Lignocellulosic Biomass to Furan Platform Chemicals: From Pretreatment to Enzyme Catalysis. Catalysts 2020, 10, 743. [CrossRef]

12. Eisentraut, A.; Sustainable Production of Second-Generation Biofuels. Organisation for Economic Co-operation and Development-Inernational Energy Agency (OECD-IEA). 2010. Available online: https://www.oecd.org/berlin/44567743.pdf (accessed on 26 September 2020).

13. United Nations Conference on Trade and Development. Second Generation Biofuel Markets: State of Play, Trade and Developing Country Perspectives; United Nations Conference on Trade and Development: Geneva, Switzerland, 2016; Available online: https://www.sdgfund.org/second-generation-biofuel-markets-stateplay-trade-and-developing-country-perspectives (accessed on 26 September 2020).

14. Wegenhart, B.L.; Liu, S.; Thom, M.; Stanley, D.; Abu-Omar, M.M. Solvent-Free Methods for Making Acetals Derived from Glycerol and Furfural and Their Use as a Biodiesel Fuel Component. ACS Catal. 2012, 2, 2524-2530. [CrossRef]

15. Werpy, T.A.; Petersen, G. Results of Screening for Potential Candidates from Sugars and Synthesis Gas. In Top Value Added Chemicals from Biomass; Office of Scientific and Technical Information (OSTI): Oak Ridge, TN, USA, 2004; Volume I, 76p.

16. Pagliaro, M.; Ciriminna, R.; Kimura, H.; Rossi, M.; Della Pina, C. From Glycerol to Value-Added Products. Angew. Chem. Int. Ed. 2007, 46, 4434-4440. [CrossRef]

17. Jiménez, R.X.; Young, A.F.; Fernandes, H.L. Propylene glycol from glycerol: Process evaluation and break-even price determination. Renew. Energy 2020, 158, 181-191. [CrossRef]

18. Iliuta, I.; Iliuta, M.C. Integration of sorption-enhanced steam glycerol reforming with methanation of in-situ removed carbon dioxide-An alternative for glycerol valorization. Int. J. Hydrogen Energy 2020, 45, 18574-18586. [CrossRef]

19. Muelas, A.; Remacha, P.; Pina, A.; Barroso, J.; Sobrino, A.; Aranda, D.; Bayarri, N.; Estévez, C.; Ballester, J. Combustion of crude glycerol and its blends with acetals. Exp. Therm. Fluid Sci. 2020, 114, 110076. [CrossRef]

20. Roslan, N.A.; Abidin, S.Z.; Ideris, A.; Vo, D.-V.N. A review on glycerol reforming processes over Ni-based catalyst for hydrogen and syngas productions. Int. J. Hydrogen Energy 2020, 45, 18466-18489. [CrossRef]

21. Kosamia, N.M.; Samavi, M.; Uprety, B.K.; Rakshit, S.K. Valorization of Biodiesel Byproduct Crude Glycerol for the Production of Bioenergy and Biochemicals. Catalysts 2020, 10, 609. [CrossRef]

22. Nda-Umar, U.I.; Ramli, I.; Taufiq-Yap, Y.H.; Muhamad, E.N. An Overview of Recent Research in the Conversion of Glycerol into Biofuels, Fuel Additives and other Bio-Based Chemicals. Catalysts 2018, 9, 15. [CrossRef] 
23. Simoes, M.; Baranton, S.; Coutanceau, C. Electrochemical Valorisation of Glycerol. ChemSusChem 2012, 5, 2106-2124. [CrossRef]

24. Fiorani, G.; Perosa, A.; Selva, M. Dimethyl carbonate: A versatile reagent for a sustainable valorization of renewables. Green Chem. 2018, 20, 288-322. [CrossRef]

25. New Glycerol Upgrading Processes. Available online: https://www.mdpi.com/journal/catalysts/special_ issues/glycerol_processes (accessed on 26 September 2020).

26. Pagliaro, M. Glycerol The Renewable Platform Chemical, 1st ed.; Else: Amsterdam, The Netherlands, 2017; ISBN 978-0-12-812205-1.

27. Mota, C.; Pinto, B.P.; Lima, A.L. De Glycerol A Versatile Renewable Feedstock for the Chemical Industry; Springer International Publishing: Cham, Switzerland, 2017; ISBN 978-3-319-59375-3.

28. Konwar, L.J.; Mikkola, J.-P.; Bordoloi, N.; Saikia, R.; Chutia, R.S.; Kataki, R. Sidestreams From Bioenergy and Biorefinery Complexes as a Resource for Circular Bioeconomy. In Waste Biorefinery; Elsevier BV: Amsterdam, The Netherlands, 2018; pp. 85-125.

29. Liu, B.; Gao, F. Navigating Glycerol Conversion Roadmap and Heterogeneous Catalyst Selection Aided by Density Functional Theory: A Review. Catalysts 2018, 8, 44. [CrossRef]

30. European Union Production of Cyclic Carbonates from $\mathrm{CO}_{2}$ Using Renewable Feedstocks. Available online: https://cordis.europa.eu/project/id/309497/es (accessed on 26 September 2020).

31. European Union Glycerol Biorefinery Approach for the Production of High Quality Products of Industrial Value. Available online: https://cordis.europa.eu/project/id/613667/es (accessed on 26 September 2020).

32. OECD-FAO. Food and Agriculture Organization of the United Nations; OECD-FAO: Paris, France, 2020.

33. Thanh, L.T.; Okitsu, K.; Van Boi, L.; Maeda, Y. Catalytic Technologies for Biodiesel Fuel Production and Utilization of Glycerol: A Review. Catalysts 2012, 2, 191-222. [CrossRef]

34. Jun, C.-H. Transition metal-catalyzed carbon-carbon bond activation. Chem. Soc. Rev. 2004, 33, 610-618. [CrossRef] [PubMed]

35. Mizugaki, T.; Kaneda, K. Development of High Performance Heterogeneous Catalysts for Selective Cleavage of $\mathrm{C}-\mathrm{O}$ and $\mathrm{C}-\mathrm{C}$ Bonds of Biomass-Derived Oxygenates. Chem. Rec. 2018, 19, 1179-1198. [CrossRef] [PubMed]

36. Santoro, S.; Kozhushkov, S.I.; Ackermann, L.; Vaccaro, L. Heterogeneous catalytic approaches in C-H activation reactions. Green Chem. 2016, 18, 3471-3493. [CrossRef]

37. Chen, Y.; Miao, B.; Zhang, M.; Chen, Y.; Wang, L. Mechanism of C-C and C-H bond cleavage in ethanol oxidation reaction on $\mathrm{Cu}_{2} \mathrm{O}(111)$ : A DFT-D and DFT+U study. Phys. Chem. Chem. Phys. 2017, 19, 26210-26220. [CrossRef]

38. Pitt, F.D.; Domingos, A.M.; Barros, A.C. Purification of residual glycerol recovered from biodiesel production. S. Afr. J. Chem. Eng. 2019, 29, 42-51. [CrossRef]

39. Meier, T.R.W.; Cremonez, P.A.; Maniglia, T.C.; Sampaio, S.C.; Teleken, J.G.; Da Silva, E.A. Production of biohydrogen by an anaerobic digestion process using the residual glycerol from biodiesel production as additive to cassava wastewater. J. Clean. Prod. 2020, 258, 120833. [CrossRef]

40. Estévez-Toledano, R.C.; Aguado-Deblas, L.; Bautista, F.M.; Luna, D.; Luna, C.; Calero, J.; Posadillo, A.; Romero, A.A. Biodiesel at the Crossroads: A Critical Review. Catalysts 2019, 9, 1033. [CrossRef]

41. Kim, K.H.; Lee, E.Y. Environmentally-Benign Dimethyl Carbonate-Mediated Production of Chemicals and Biofuels from Renewable Bio-Oil. Energies 2017, 10, 1790. [CrossRef]

42. Habaki, H.; Hayashi, T.; Sinthupinyo, P.; Egashira, R. Purification of glycerol from transesterification using activated carbon prepared from Jatropha Shell for biodiesel production. J. Environ. Chem. Eng. 2019, 7, 103303. [CrossRef]

43. Setyawan, H.Y.; Zhu, M.; Zhang, Z.; Zhang, D. An Experimental Study of Effect of Water on Ignition and Combustion Characteristics of Single Droplets of Glycerol. Energy Procedia 2015, 75, 578-583. [CrossRef]

44. Menon, A.; Waller, N.; Hu, W.; Hayhurst, A.; Davidson, J.; Scott, S.A. The combustion of solid paraffin wax and of liquid glycerol in a fluidised bed. Fuel 2017, 199, 447-455. [CrossRef]

45. Presciutti, A.; Asdrubali, F.; Baldinelli, G.; Rotili, A.; Malavasi, M.; Di Salvia, G. Energy and exergy analysis of glycerol combustion in an innovative flameless power plant. J. Clean. Prod. 2018, 172, 3817-3824. [CrossRef]

46. Mehrpooya, M.; Ghorbani, B.; Abedi, H. Biodiesel production integrated with glycerol steam reforming process, solid oxide fuel cell (SOFC) power plant. Energy Convers. Manag. 2020, 206, 112467. [CrossRef] 
47. Lee, B.-H.; Sh, L.; Bae, J.-S.; Choi, Y.-C.; Jeon, C.H. Combustion behavior of low-rank coal impregnated with glycerol. Biomass Bioenergy 2016, 87, 122-130. [CrossRef]

48. Gibson, I.; Slim, C.J.; Zheng, Y.; Scott, S.A.; Davidson, J.F.; Hayhurst, A. The continuous combustion of glycerol in a fluidised bed. Combust. Flame 2019, 200, 60-68. [CrossRef]

49. Żukowski, W.; Berkowicz, G. Dataset on flue gas composition during combustion in the fluidised bed reactor. Glycerol combustion. Data Brief 2020, 30, 105418. [CrossRef]

50. Fantozzi, F.; Frassoldati, A.; Bartocci, P.; Cinti, G.; Quagliarini, F.; Bidini, G.; Ranzi, E. An experimental and kinetic modeling study of glycerol pyrolysis. Appl. Energy 2016, 184, 68-76. [CrossRef]

51. Almazrouei, M.; Janajreh, I. Model-fitting approach to kinetic analysis of non-isothermal pyrolysis of pure and crude glycerol. Renew. Energy 2020, 145, 1693-1708. [CrossRef]

52. He, S.; Muizebelt, I.; Heeres, A.; Schenk, N.; Blees, R.; Heeres, H. Catalytic pyrolysis of crude glycerol over shaped ZSM-5/bentonite catalysts for bio-BTX synthesis. Appl. Catal. B Environ. 2018, 235, 45-55. [CrossRef]

53. De OliveiraMaia, D.; de SouzaChagas, A.M.; Araújo, A.M.D.M.; De Mendonça, A.V.; Ferreira, I.M.D.L.; Lemos, F.; Araujo, A.S.; Fernandes, V.J.; Gondim, A.D. Catalytic pyrolysis of glycerol in the presence of Nickel (II) Schiff base complex supported in SBA-15: Kinetic and products (TG-FTIR and PY-CG/MS). Thermochim. Acta 2018, 669, 160-168. [CrossRef]

54. Batista, L.M.B.; Oliveira, J.L.F.; Bezerra, F.A.; Araújo, A.M.D.M.; Júnior, V.J.F.; Araujo, A.S.; Alves, A.P.; Gondim, A.D. Synthesis, characterization and evaluation of niobium catalysts in the flash pyrolysis of glycerol. Solid State Sci. 2019, 97, 105977. [CrossRef]

55. Shahirah, M.N.N.; Gimbun, J.; Ideris, A.; Khan, M.R.; Cheng, C.-K. Catalytic pyrolysis of glycerol into syngas over ceria-promoted $\mathrm{Ni} / \alpha-\mathrm{Al}_{2} \mathrm{O}_{3}$ catalyst. Renew. Energy 2017, 107, 223-234. [CrossRef]

56. Shahirah, M.N.N.; Gimbun, J.; Lam, S.S.; Ng, Y.H.; Cheng, C.-K. Synthesis and characterization of a La $\mathrm{Ni} / \alpha-\mathrm{Al}_{2} \mathrm{O}_{3}$ catalyst and its use in pyrolysis of glycerol to syngas. Renew. Energy 2019, 132, 1389-1401. [CrossRef]

57. Fasolini, A.; Cespi, D.; Tabanelli, T.; Cucciniello, R.; Cavani, F. Hydrogen from Renewables: A Case Study of Glycerol Reforming. Catalysts 2019, 9, 722. [CrossRef]

58. Sabio, E.; Álvarez-Murillo, A.; González, J.; Ledesma, B.; Román, S. Modelling the composition of the gas obtained by steam reforming of glycerine. Energy Convers. Manag. 2017, 146, 147-157. [CrossRef]

59. Román, S.; Ledesma, B.; Alvarez, A.; Al-Kassir, A.; Yusaf, T.; Cano, B.L. Glycerin, a Biodiesel By-Product with Potentiality to Produce Hydrogen by Steam Gasification. Energies 2015, 8, 12765-12775. [CrossRef]

60. Charisiou, N.; Polychronopoulou, K.; Asif, A.; Goula, M. The potential of glycerol and phenol towards $\mathrm{H}_{2}$ production using steam reforming reaction: A review. Surf. Coat. Technol. 2018, 352, 92-111. [CrossRef]

61. Bepari, S.; Kuila, D. Steam reforming of methanol, ethanol and glycerol over nickel-based catalysts-A review. Int. J. Hydrogen Energy 2020, 45, 18090-18113. [CrossRef]

62. Wang, B.; Xiong, Y.; Han, Y.; Hong, J.; Zhang, Y.; Li, J.; Jing, F.; Chu, W. Preparation of stable and highly active $\mathrm{Ni} / \mathrm{CeO}_{2}$ catalysts by glow discharge plasma technique for glycerol steam reforming. Appl. Catal. B Environ. 2019, 249, 257-265. [CrossRef]

63. Xiong, Y.; Wang, B.; Yan, J.; Hong, J.; Wang, L.; Zhang, Y.; Li, J.; Jing, F.; Chu, W. Plasma assisted preparation of nickel-based catalysts supported on $\mathrm{CeO}_{2}$ with different morphologies for hydrogen production by glycerol steam reforming. Powder Technol. 2019, 354, 324-332. [CrossRef]

64. Yang, X.; Wang, S.; Li, Z.; Zhang, K.; Li, B. Enhancement of membrane hydrogen separation on glycerol steam reforming in a fluidized bed reactor. Int. J. Hydrogen Energy 2018, 43, 18863-18872. [CrossRef]

65. Macedo, M.S.; Soria, M.; Madeira, L.M. Glycerol steam reforming for hydrogen production: Traditional versus membrane reactor. Int. J. Hydrogen Energy 2019, 44, 24719-24732. [CrossRef]

66. Saidi, M.; Moradi, P. Conversion of biodiesel synthesis waste to hydrogen in membrane reactor: Theoretical study of glycerol steam reforming. Int. J. Hydrogen Energy 2020, 45, 8715-8726. [CrossRef]

67. Ghasemzadeh, K.; Ghahremani, M.; Amiri, T.Y.; Basile, A. Performance evaluation of Pd Ag membrane reactor in glycerol steam reforming process: Development of the CFD model. Int. J. Hydrogen Energy 2019, 44, 1000-1009. [CrossRef]

68. Yang, X.; Wang, S.; Liu, H.; Liu, G.; He, Y. Numerical studies of sorption-enhanced glycerol steam reforming in a fluidized bed membrane reactor at low temperature. Int. J. Hydrogen Energy 2020, 45, 8346-8356. [CrossRef] 
69. Bac, S.; Keskin, S.; Avci, A.K. Recent advances in materials for high purity $\mathrm{H}_{2}$ production by ethanol and glycerol steam reforming. Int. J. Hydrogen Energy 2019. [CrossRef]

70. Chen, M.; Zhou, Z.; Wang, Y.; Liang, T.; Li, X.; Yang, Z.; Chen, M.; Wang, J. Effects of attapulgite-supported transition metals catalysts on glycerol steam reforming for hydrogen production. Int. J. Hydrogen Energy 2018, 43, 20451-20464. [CrossRef]

71. Dahdah, E.; Aouad, S.; Gennequin, C.; Estephane, J.; Nsouli, B.; Aboukaïs, A.; Abi-Aad, E. Glycerol steam reforming over $\mathrm{Ru}-\mathrm{Mg}-\mathrm{Al}$ hydrotalcite-derived mixed oxides: Role of the preparation method in catalytic activity. Int. J. Hydrogen Energy 2018, 43, 19864-19872. [CrossRef]

72. Dobosz, J.; Cichy, M.; Zawadzki, M.; Borowiecki, T. Glycerol steam reforming over calcium hydroxyapatite supported cobalt and cobalt-cerium catalysts. J. Energy Chem. 2018, 27, 404-412. [CrossRef]

73. Lima, D.S.; Calgaro, C.O.; Perez-Lopez, O.W. Hydrogen production by glycerol steam reforming over Ni based catalysts prepared by different methods. Biomass Bioenergy 2019, 130, 105358. [CrossRef]

74. Moreira, R.; Moral, A.; Bimbela, F.; Portugal, A.; Ferreira, A.; Sanchez, J.L.; Gandía, L.M. Syngas production via catalytic oxidative steam reforming of glycerol using a $\mathrm{Co} / \mathrm{Al}$ coprecipitated catalyst and different bed fillers. Fuel Process. Technol. 2019, 189, 120-133. [CrossRef]

75. Silva, J.M.; Ribeiro, L.S.; Órfão, J.; Soria, M.; Madeira, L.M. Low temperature glycerol steam reforming over a Rh-based catalyst combined with oxidative regeneration. Int. J. Hydrogen Energy 2019, 44, 2461-2473. [CrossRef]

76. Zhao, H.; Xu, C.-H.; Wang, T. Production of methane from biomass glycerol through coupling of steam reforming and methanation on $\mathrm{Ni}-\mathrm{Mn} / \mathrm{Al}_{2} \mathrm{O}_{3}$. Sustain. Chem. Pharm. 2019, 13, 100150. [CrossRef]

77. Al-Salihi, S.; Abrokwah, R.; Dade, W.; Deshmane, V.; Hossain, T.; Kuila, D. Renewable hydrogen from glycerol steam reforming using $\mathrm{Co}-\mathrm{Ni}-\mathrm{MgO}$ based SBA-15 nanocatalysts. Int. J. Hydrogen Energy 2020, 45, 14183-14198. [CrossRef]

78. Charisiou, N.; Italiano, C.; Pino, L.; Sebastian, V.; Vita, A.; Goula, M. Hydrogen production via steam reforming of glycerol over $\mathrm{Rh} / \gamma-\mathrm{Al}_{2} \mathrm{O}_{3}$ catalysts modified with $\mathrm{CeO}_{2}, \mathrm{MgO}$ or $\mathrm{La}_{2} \mathrm{O}_{3}$. Renew. Energy 2020, 162, 908-925. [CrossRef]

79. Chen, D.; Wang, W.; Liu, C. Hydrogen production through glycerol steam reforming over beehive-biomimetic graphene-encapsulated nickel catalysts. Renew. Energy 2020, 145, 2647-2657. [CrossRef]

80. Dahdah, E.; Estephane, J.; Gennequin, C.; Aboukaïs, A.; Abi-Aad, E.; Aouad, S. Zirconia supported nickel catalysts for glycerol steam reforming: Effect of zirconia structure on the catalytic performance. Int. J. Hydrogen Energy 2020, 45, 4457-4467. [CrossRef]

81. Dahdah, E.; Estephane, J.; Gennequin, C.; Aboukaïs, A.; Aouad, S.; Abi-Aad, E. Effect of La promotion on $\mathrm{Ni} / \mathrm{Mg}-\mathrm{Al}$ hydrotalcite derived catalysts for glycerol steam reforming. J. Environ. Chem. Eng. 2020, 8, 104228. [CrossRef]

82. Feng, P.; Huang, K.; Xu, Q.; Qi, W.; Xin, S.; Wei, T.; Liao, L.; Yan, Y. Ni supported on the CaO modified attapulgite as catalysts for hydrogen production from glycerol steam reforming. Int. J. Hydrogen Energy 2020, 45, 8223-8233. [CrossRef]

83. Ismaila, A.; Chen, H.; Shao, Y.; Xu, S.; Jiao, Y.; Chen, X.; Gao, X.; Fan, X. Renewable hydrogen production from steam reforming of glycerol (SRG) over ceria-modified $\gamma$-alumina supported Ni catalyst. Chin. J. Chem. Eng. 2020, 28, 2328-2336. [CrossRef]

84. Jing, F.; Liu, S.; Wang, R.; Li, X.; Yan, Z.; Luo, S.; Chu, W. Hydrogen production through glycerol steam reforming over the NiCexAl catalysts. Renew. Energy 2020, 158, 192-201. [CrossRef]

85. Menezes, J.P.D.S.; Duarte, K.R.; Manfro, R.L.; Souza, M.M.V.M. Effect of niobia addition on cobalt catalysts supported on alumina for glycerol steam reforming. Renew. Energy 2020, 148, 864-875. [CrossRef]

86. Moogi, S.; Nakka, L.; Potharaju, S.P.; Ahmed, A.; Farooq, A.; Jung, S.-C.; Rhee, G.H.; Park, Y.-K. Copper promoted $\mathrm{Co} / \mathrm{MgO}:$ A stable and efficient catalyst for glycerol steam reforming. Int. J. Hydrogen Energy 2020. [CrossRef]

87. Moogi, S.; Lee, I.-G.; Hwang, K.-R. Catalytic steam reforming of glycerol over Ni-La2O3-CeO2/SBA-15 catalyst for stable hydrogen-rich gas production. Int. J. Hydrogen Energy 2020. [CrossRef]

88. García, L.; Valiente, A.; Oliva, M.; Ruiz, J.; Arauzo, J. Influence of operating variables on the aqueous-phase reforming of glycerol over a Ni/Al coprecipitated catalyst. Int. J. Hydrogen Energy 2018, 43, 20392-20407. [CrossRef] 
89. Shabaker, J.; Huber, G.; Dumesic, J. Aqueous-phase reforming of oxygenated hydrocarbons over Sn-modified Ni catalysts. J. Catal. 2004, 222, 180-191. [CrossRef]

90. Shabaker, J. Aqueous-phase reforming of methanol and ethylene glycol over alumina-supported platinum catalysts. J. Catal. 2003, 215, 344-352. [CrossRef]

91. Bastan, F.; Kazemeini, M.; Larimi, A.; Maleki, H. Production of renewable hydrogen through aqueous-phase reforming of glycerol over $\mathrm{Ni} / \mathrm{Al} 2 \mathrm{O} 3 \mathrm{MgO}$ nano-catalyst. Int. J. Hydrogen Energy 2018, 43, 614-621. [CrossRef]

92. Reynoso, A.; Ayastuy, J.; Iriarte-Velasco, U.; Gutiérrez-Ortiz, M. Cobalt aluminate spinel-derived catalysts for glycerol aqueous phase reforming. Appl. Catal. B Environ. 2018, 239, 86-101. [CrossRef]

93. Bossola, F.; Pereira-Hernández, X.I.; Evangelisti, C.; Wang, Y.; Santo, V.D. Investigation of the promoting effect of $\mathrm{Mn}$ on a Pt/C catalyst for the steam and aqueous phase reforming of glycerol. J. Catal. 2017, 349, 75-83. [CrossRef]

94. Putra, R.D.D.; Trajano, H.L.; Liu, S.; Smith, K.J.; Smith, K.; Kim, C.-S. In-situ glycerol aqueous phase reforming and phenol hydrogenation over Raney $\mathrm{Ni}^{\circledR}$. Chem. Eng. J. 2018, 350, 181-191. [CrossRef]

95. Liu, S.; Tamura, M.; Shen, Z.; Su, Y.; Nakagawa, Y.; Tomishige, K. Hydrogenolysis of glycerol with in-situ produced $\mathrm{H}_{2}$ by aqueous-phase reforming of glycerol using Pt-modified $\mathrm{Ir}-\mathrm{ReO}_{\mathrm{x}} / \mathrm{SiO}_{2}$ catalyst. Catal. Today 2018, 303, 106-116. [CrossRef]

96. Thirabunjongcharoen, S.; Bumroongsakulsawat, P.; Praserthdam, P.; Charojrochkul, S.; Assabumrungrat, S.; Kim-Lohsoontorn, P. Thermally double coupled reactor coupling aqueous phase glycerol reforming and methanol synthesis. Catal. Today 2020. [CrossRef]

97. Callison, J.; Subramanian, N.; Rogers, S.; Chutia, A.; Gianolio, D.; Catlow, C.; Wells, P.; Dimitratos, N. Directed aqueous-phase reforming of glycerol through tailored platinum nanoparticles. Appl. Catal. B Environ. 2018, 238, 618-628. [CrossRef]

98. Morales-Marín, A.; Ayastuy, J.; Iriarte-Velasco, U.; Gutiérrez-Ortiz, M. Nickel aluminate spinel-derived catalysts for the aqueous phase reforming of glycerol: Effect of reduction temperature. Appl. Catal. B Environ. 2019, 244, 931-945. [CrossRef]

99. Reynoso, A.; Iriarte-Velasco, U.; Gutiérrez-Ortiz, M.; Ayastuy, J. Highly stable Pt/CoAl2O4 catalysts in Aqueous-Phase Reforming of glycerol. Catal. Today 2020. [CrossRef]

100. Yu, J.; Odriozola, J.A.; Reina, T. Dry Reforming of Ethanol and Glycerol: Mini-Review. Catalysts 2019, 9, 1015. [CrossRef]

101. Dang, C.; Wu, S.; Yang, G.; Cao, Y.; Wang, H.; Peng, F.; Yu, H. Syngas production by dry reforming of the mixture of glycerol and ethanol with $\mathrm{CaCO}_{3}$. J. Energy Chem. 2020, 43, 90-97. [CrossRef]

102. Harun, N.; Abidin, S.Z.; Osazuwa, O.U.; Taufiq-Yap, Y.H.; Azizan, M.T. Hydrogen production from glycerol dry reforming over Ag-promoted $\mathrm{Ni} / \mathrm{Al}_{2} \mathrm{O}_{3}$. Int. J. Hydrogen Energy 2019, 44, 213-225. [CrossRef]

103. Tavanarad, M.; Meshkani, F.; Rezaei, M. Production of syngas via glycerol dry reforming on Ni catalysts supported on mesoporous nanocrystalline $\mathrm{Al}_{2} \mathrm{O}_{3}$. J. CO2 Util. 2018, 24, 298-305. [CrossRef]

104. Bulutoglu, P.S.; Say, Z.; Bac, S.; Ozensoy, E.; Avci, A.K. Dry reforming of glycerol over Rh-based ceria and zirconia catalysts: New insights on catalyst activity and stability. Appl. Catal. A Gen. 2018, 564, 157-171. [CrossRef]

105. Arif, N.N.M.; Abidin, S.Z.; Osazuwa, O.U.; Vo, D.N.; Azizan, M.T.; Taufiq-Yap, Y.H. Hydrogen production via $\mathrm{CO}_{2}$ dry reforming of glycerol over Re Ni/CaO catalysts. Int. J. Hydrogen Energy 2019, 44, 20857-20871. [CrossRef]

106. El Doukkali, M.; Iriondo, A.; Gandarias, I. Enhanced catalytic upgrading of glycerol into high value-added $\mathrm{H}_{2}$ and propanediols: Recent developments and future perspectives. Mol. Catal. 2020, 490, 110928. [CrossRef]

107. Zhou, C.H.; Zhao, H.; Tong, D.S.; Wu, L.M.; Yu, W.H. Recent Advances in Catalytic Conversion of Glycerol. Catal. Rev. 2013, 55, 369-453. [CrossRef]

108. Wang, Y.; Xiao, Y.; Xiao, G. Sustainable value-added C3 chemicals from glycerol transformations: A mini review for heterogeneous catalytic processes. Chin. J. Chem. Eng. 2019, 27, 1536-1542. [CrossRef]

109. Feng, J.; Xu, B. Reaction Mechanisms for the Heterogeneous Hydrogenolysis of Biomass-Derived Glycerol to Propanediols. Prog. React. Kinet. Mech. 2014, 39, 1-15. [CrossRef]

110. Zhu, S.; Gao, X.; Zhu, Y.; Fan, W.; Wang, J.; Li, Y. A highly efficient and robust $\mathrm{Cu} / \mathrm{SiO}_{2}$ catalyst prepared by the ammonia evaporation hydrothermal method for glycerol hydrogenolysis to 1,2-propanediol. Catal. Sci. Technol. 2015, 5, 1169-1180. [CrossRef] 
111. Vila, F.; Granados, M.L.; Ojeda, M.; Fierro, J.L.G.; Mariscal, R. Glycerol hydrogenolysis to 1,2-propanediol with $\mathrm{Cu} / \gamma-\mathrm{Al}_{2} \mathrm{O}_{3}$ : Effect of the activation process. Catal. Today 2012, 187, 122-128. [CrossRef]

112. Xia, S.; Yuan, Z.; Wang, L.; Chen, P.; Hou, Z. Catalytic production of 1,2-propanediol from glycerol in bio-ethanol solvent. Bioresour. Technol. 2012, 104, 814-817. [CrossRef] [PubMed]

113. Kim, N.D.; Park, J.R.; Park, D.S.; Kwak, B.K.; Yi, J. Promoter effect of Pd in CuCr2O4 catalysts on the hydrogenolysis of glycerol to 1,2-propanediol. Green Chem. 2012, 14, 2638-2646. [CrossRef]

114. Zhou, M.; Yang, M.; Yang, X.; Zhao, X.; Sun, L.; Deng, W.; Wang, A.; Li, J.; Zhang, T. On the mechanism of $\mathrm{H}_{2}$ activation over single-atom catalyst: An understanding of $\mathrm{Pt}_{1} / \mathrm{WO}_{\mathrm{x}}$ in the hydrogenolysis reaction. Chin. J. Catal. 2020, 41, 524-532. [CrossRef]

115. Mane, R.; Patil, S.; Shirai, M.; Rayalu, S.S.; Rode, C.V. Influence of carbon based supports on selectivity behavior of diols and propanol in Ru catalyzed glycerol hydrogenolysis. Appl. Catal. B Environ. 2017, 204, 134-146. [CrossRef]

116. Gallegos-Suarez, E.; Guerrero-Ruiz, A.; Rodríguez-Ramos, I.; Arcoya, A. Comparative study of the hydrogenolysis of glycerol over Ru-based catalysts supported on activated carbon, graphite, carbon nanotubes and KL-zeolite. Chem. Eng. J. 2015, 262, 326-333. [CrossRef]

117. Seguel, J.; García, R.; Chimentão, R.J.; Fierro, J.L.G.; Ghampson, I.T.; Escalona, N.; Sepúlveda, C. Thermal Modification Effect on Supported Cu-Based Activated Carbon Catalyst in Hydrogenolysis of Glycerol. Materials 2020, 13, 603. [CrossRef]

118. Costa, J.D.R.M.; Santos, R.C.; Coutinho, L.P.; Silva, O.R.; Barros, H.O.; Freire, V.N.; Valentini, A. $\mathrm{CO}_{2}$ role on the glycerol conversion over catalyst containing $\mathrm{CaO}-\mathrm{SiO}_{2}$ doped with $\mathrm{Ag}$ and Pt. Catal. Today 2020, 344, 199-211. [CrossRef]

119. Mane, R.; Rode, C. Simultaneous glycerol dehydration and in situ hydrogenolysis over Cu-Al oxide under an inert atmosphere. Green Chem. 2012, 14, 2780-2789. [CrossRef]

120. Checa, M.; Montes, V.; Hidalgo-Carrillo, J.; Marinas, A.; Urbano, F.J. Influence of Boron, Tungsten and Molybdenum Modifiers on Zirconia Based Pt Catalyst for Glycerol Valorization. Nanomaterials 2019, 9, 509. [CrossRef]

121. Kuljiraseth, J.; Kumpradit, T.; Leungcharoenwattana, T.; Poo-Arporn, Y.; Jitkarnka, S. Integrated glyceroland ethanol-based chemical synthesis routes using $\mathrm{Cu}-\mathrm{Mg}-\mathrm{Al} \mathrm{LDH}$-derived catalysts without external hydrogen: Intervention of bio-ethanol co-fed with glycerol. Renew. Energy 2020, 156, 975-985. [CrossRef]

122. Shan, J.; Liu, H.; Lu, K.; Zhu, S.; Li, J.; Wang, J.; Fan, W. Identification of the dehydration active sites in glycerol hydrogenolysis to 1,2-propanediol over $\mathrm{Cu} / \mathrm{SiO}_{2}$ catalysts. J. Catal. 2020, 383, 13-23. [CrossRef]

123. Żelazny, A.; Samson, K.; Grabowski, R.; Śliwa, M.; Ruggiero-Mikołajczyk, M.; Kornas, A. Hydrogenolysis of glycerol to propylene glycol over $\mathrm{Cu}$ /oxide catalysts: Influence of the support and reaction conditions. React. Kinet. Mech. Catal. 2017, 121, 329-343. [CrossRef]

124. Ke, Y.; Li, X.; Li, J.; Liu, C.; Xu, C.; Dong, W. Conversion of glycerol to dihydroxyacetone over Au catalysts on various supports. J. Chem. Technol. Biotechnol. 2019, 95, 1153-1162. [CrossRef]

125. Checa-Gómez, M.; Marinas, A.; Marinas, J.M.; Urbano, F.J. Deactivation study of supported Pt catalyst on glycerol hydrogenolysis. Appl. Catal. A Gen. 2015, 507, 34-43. [CrossRef]

126. García-Fernández, S.; Gandarias, I.; Tejido-Núñez, Y.; Requies, J.; Arias, P.L. Influence of the Support of Bimetallic Platinum Tungstate Catalysts on 1,3-Propanediol Formation from Glycerol. ChemCatChem 2017, 9 , 4508-4519. [CrossRef]

127. De Andrade, T.S.; Souza, M.M.; Manfro, R.L. Hydrogenolysis of glycerol to 1,2-propanediol without external $\mathrm{H}_{2}$ addition in alkaline medium using Ni-Cu catalysts supported on Y zeolite. Renew. Energy 2020, 160, 919-930. [CrossRef]

128. Priya, S.S.; Bhanuchander, P.; Kumar, V.P.; Dumbre, D.K.; Periasamy, S.R.; Bhargava, S.K.; Mannepalli, L.K.; Chary, K.V.R. Platinum Supported on H-Mordenite: A Highly Efficient Catalyst for Selective Hydrogenolysis of Glycerol to 1,3-Propanediol. ACS Sustain. Chem. Eng. 2016, 4, 1212-1222. [CrossRef]

129. Li, X.; Xiang, M.; Wu, D. Hydrogenolysis of glycerol over bimetallic Cu Ni catalysts supported on hierarchically porous SAPO-11 zeolite. Catal. Commun. 2019, 119, 170-175. [CrossRef]

130. Li, X.; Wu, D. Synthesis of Co-doped micro-mesoporous SAPO-11 zeolite for glycerol hydrogenolysis. Korean J. Chem. Eng. 2020, 37, 216-223. [CrossRef] 
131. Gebretsadik, F.B.; Llorca, J.; Salagre, P.; Cesteros, Y. Hydrogenolysis of Glycidol as an Alternative Route to Obtain 1,3-Propanediol Selectively Using $\mathrm{MO}_{\mathrm{x}}$-Modified Nickel-Copper Catalysts Supported on Acid Mesoporous Saponite. ChemCatChem 2017, 9, 3670-3680. [CrossRef]

132. Li, X.; Wu, Q.; Zhang, B.; Zhang, C.; Lin, W.; Cheng, H.; Zhao, F. Efficient conversion of glycerol to 1, 2-propenadiol over $\mathrm{ZnPd} / \mathrm{ZnO}-3 \mathrm{Al}$ catalyst: The significant influences of calcination temperature. Catal. Today 2018, 302, 210-216. [CrossRef]

133. Lei, N.; Miao, Z.; Liu, F.; Wang, H.; Pan, X.; Wang, A.; Zhang, T. Understanding the deactivation behavior of $\mathrm{Pt} / \mathrm{WO}_{3} / \mathrm{Al}_{2} \mathrm{O}_{3}$ catalyst in the glycerol hydrogenolysis reaction. Chin. J. Catal. 2020, 41, 1261-1267. [CrossRef]

134. Liang, Y.; Shi, G.; Jin, K. Promotion Effect of $\mathrm{Al}_{2} \mathrm{O}_{3}$ on $\mathrm{Pt}-\mathrm{WO}_{\mathrm{x}} / \mathrm{SiO}_{2}$ Catalysts for Selective Hydrogenolysis of Bioglycerol to 1,3-Propanediol in Liquid Phase. Catal. Lett. 2020, 150, 2365-2376. [CrossRef]

135. Xi, Z.; Jia, W.; Zhu, Z. $\mathrm{WO}_{3}-\mathrm{ZrO}_{2}-\mathrm{TiO}_{2}$ Composite Oxide Supported Pt as an Efficient Catalyst for Continuous Hydrogenolysis of Glycerol. Catal. Lett. 2020, 1-14. [CrossRef]

136. Zhou, W.; Li, Y.; Wang, X.; Yao, D.; Wang, Y.; Huang, S.; Li, W.; Zhao, Y.; Wang, S.; Ma, X. Insight into the nature of Brönsted acidity of Pt-(WOx)n-H model catalysts in glycerol hydrogenolysis. J. Catal. 2020, 388, 154-163. [CrossRef]

137. Vasiliadou, E.S.; Lemonidou, A.A. Glycerol transformation to value added C3 diols: Reaction mechanism, kinetic, and engineering aspects. Wiley Interdiscip. Rev. Energy Environ. 2014, 4, 486-520. [CrossRef]

138. Chimentão, R.; Miranda, B.; Ruiz, D.; Gispert-Guirado, F.; Medina, F.; Llorca, J.; Santos, J. Catalytic performance of zinc-supported copper and nickel catalysts in the glycerol hydrogenolysis. J. Energy Chem. 2020, 42, 185-194. [CrossRef]

139. Kandasamy, S.; Samudrala, S.P.; Bhattacharya, S. The route towards sustainable production of ethylene glycol from a renewable resource, biodiesel waste: A review. Catal. Sci. Technol. 2019, 9, 567-577. [CrossRef]

140. Nakagawa, Y.; Tamura, M.; Tomishige, K. Perspective on catalyst development for glycerol reduction to C3 chemicals with molecular hydrogen. Res. Chem. Intermed. 2018, 44, 3879-3903. [CrossRef]

141. Pandey, D.K.; Pandhare, N.N.; Biswas, P. Production of propylene glycol (propane-1,2-diol) in vapor phase over $\mathrm{Cu}-\mathrm{Ni} / \gamma-\mathrm{Al}_{2} \mathrm{O}_{3}$ catalyst in a down flow tubular reactor: Effect of catalyst calcination temperature and kinetic study. React. Kinet. Mech. Catal. 2019, 127, 523-542. [CrossRef]

142. Raju, N.; Rekha, V.; Abhishek, B.; Kumar, P.M.; Sumana, C.; Lingaiah, N. Studies on continuous selective hydrogenolysis of glycerol over supported Cu-Co bimetallic catalysts. New J. Chem. 2020, 44, 3122-3128. [CrossRef]

143. Mitta, H.; Devunuri, N.; Sunkari, J.; Mutyala, S.; Putrakumar, B.; Perupogu, V.; Jyothi, S. A highly active dispersed copper oxide phase on calcined MgAlGaO catalysts in glycerol hydrogenolysis. Catal. Today 2020. [CrossRef]

144. Zhang, X.; Cui, G.; Feng, H.; Chen, L.; Wang, H.; Wang, B.; Zheng, L.; Hong, S.; Wei, M. Platinum-copper single atom alloy catalysts with high performance towards glycerol hydrogenolysis. Nat. Commun. 2019, 10, 1-12. [CrossRef] [PubMed]

145. Gatti, M.N.; Cerioni, J.L.; Pompeo, F.; Santori, G.F.; Nichio, N.N. High Yield to 1-Propanol from Crude Glycerol Using Two Reaction Steps with Ni Catalysts. Catalysts 2020, 10, 615. [CrossRef]

146. Nakagawa, Y.; Tamura, M.; Tomishige, K. Catalytic materials for the hydrogenolysis of glycerol to 1,3-propanediol. J. Mater. Chem. A 2014, 2, 6688-6702. [CrossRef]

147. Greish, A.A.; Finashina, E.D.; Tkachenko, O.P.; Nikul'Shin, P.A.; Ershov, M.A.; Kustov, L.M. Hydrodeoxygenation of glycerol into propanols over a $\mathrm{Ni} / \mathrm{WO}_{3}-\mathrm{TiO}_{2}$ catalyst. Mendeleev Commun. 2020, 30, 119-120. [CrossRef]

148. Mizugaki, T.; Yamakawa, T.; Arundhathi, R.; Mitsudome, T.; Jitsukawa, K.; Kaneda, K. Selective Hydrogenolysis of Glycerol to 1,3-Propanediol Catalyzed by Pt Nanoparticles- $\mathrm{AlO}_{\mathrm{x}} / \mathrm{WO}_{3}$. Chem. Lett. 2012, 41, 1720-1722. [CrossRef]

149. Varghese, J.J.; Cao, L.; Robertson, C.; Yang, Y.; Gladden, L.; Lapkin, A.A.; Mushrif, S.H. Synergistic Contribution of the Acidic Metal Oxide-Metal Couple and Solvent Environment in the Selective Hydrogenolysis of Glycerol: A Combined Experimental and Computational Study Using ReOx-Ir as the Catalyst. ACS Catal. 2018, 9, 485-503. [CrossRef]

150. Aihara, T.; Miura, H.; Shishido, T. Effect of perimeter interface length between $2 \mathrm{D} \mathrm{WO}_{3}$ monolayer domain and $\gamma-\mathrm{Al}_{2} \mathrm{O}_{3}$ on selective hydrogenolysis of glycerol to 1,3-propanediol. Catal. Sci. Technol. 2019, 9, 5359-5367. [CrossRef] 
151. Wang, C.; Chen, C. Stabilized hydrogenolysis of glycerol to 1,3-propanediol over Mg modified Pt/ $\mathrm{WO}_{\mathrm{x}}-\mathrm{ZrO} 2$ catalysts. React. Kinet. Mech. Catal. 2019, 128, 461-477. [CrossRef]

152. López, A.; Aragón, J.; Hernández-Cortez, J.; Mosqueira, M.; Martínez-Palou, R. Study of hydrotalcite-supported transition metals as catalysts for crude glycerol hydrogenolysis. Mol. Catal. 2019, 468, 9-18. [CrossRef]

153. Mallesham, B.; Sudarsanam, P.; Reddy, B.V.S.; Reddy, B.M. Development of cerium promoted copper-magnesium catalysts for biomass valorization: Selective hydrogenolysis of bioglycerol. Appl. Catal. B Environ. 2016, 181, 47-57. [CrossRef]

154. Kant, A.; He, Y.; Jawad, A.; Li, X.; Rezaei, F.; Smith, J.D.; Rownaghi, A.A. Hydrogenolysis of glycerol over Ni, $\mathrm{Cu}, \mathrm{Zn}$, and Zr supported on H-beta. Chem. Eng. J. 2017, 317, 1-8. [CrossRef]

155. Shozi, M.L.; Dasireddy, V.D.; Singh, S.; Mohlala, P.; Morgan, D.J.; Friedrich, H.B. Hydrogenolysis of Glycerol to Monoalcohols over Supported Mo and W Catalysts. ACS Sustain. Chem. Eng. 2016, 4, 5752-5760. [CrossRef]

156. Nanda, M.R.; Yuan, Z.; Shui, H.; Shui, H. Selective Hydrogenolysis of Glycerol and Crude Glycerol (a By-Product or Waste Stream from the Biodiesel Industry) to 1,2-Propanediol over $\mathrm{B}_{2} \mathrm{O}_{3}$ Promoted $\mathrm{Cu} / \mathrm{Al}_{2} \mathrm{O}_{3}$ Catalysts. Catalysts 2017, 7, 196. [CrossRef]

157. Zhang, G.; Jin, X.; Zhang, Q.; Cheng, Y.; Chen, X.; Liu, Y.; Feng, X.; Yang, C. PtRu/Zn ${ }_{3} \mathrm{Ce}_{1} \mathrm{O}_{\mathrm{x}}$ catalysts with Lewis acid-base pairs show synergistic performances for the conversion of glycerol in the absence of externally added $\mathrm{H}_{2}$. Catal. Sci. Technol. 2020, 10, 4386-4395. [CrossRef]

158. Cai, F.; Jin, F.; Hao, J.; Xiao, G. Selective hydrogenolysis of glycerol to 1,2-propanediol on Nb-modified Pd-Zr-Al catalysts. Catal. Commun. 2019, 131, 105801. [CrossRef]

159. Singh, B.; Kim, Y.; Kwon, S.; Na, K. Selective Catalytic Transfer Hydrogenolysis of Glycerol to 2-Isopropoxy-Propan-1-Ol over Noble Metal Ion-Exchanged Mordenite Zeolite. Catalysts 2019, 9, 885. [CrossRef]

160. Xi, Z.; Hong, Z.; Huang, F.; Zhu, Z.; Jia, W.; Li, J. Hydrogenolysis of Glycerol on the $\mathrm{ZrO}_{2}-\mathrm{TiO}_{2}$ Supported Pt-WO $\mathrm{W}_{\mathrm{x}}$ Catalyst. Catalysts 2020, 10, 312. [CrossRef]

161. Cheng, S.; Zeng, Y.; Pei, Y.; Fan, K.; Qiao, M.; Zong, B. Synthesis and Catalysis of Pt/W-s-SBA-15 Catalysts with Short Channel for Glycerol Hydrogenolysis to 1,3-Propanediol. Acta Chim. Sin. 2019, 77, 1054-1062. [CrossRef]

162. Lei, N.; Zhao, X.; Hou, B.; Yang, M.; Zhou, M.; Liu, F.; Wang, A.; Zhang, T. Effective Hydrogenolysis of Glycerol to 1,3-Propanediol over Metal-Acid Concerted Pt/ $\mathrm{WO}_{\mathrm{x}} / \mathrm{Al}_{2} \mathrm{O}_{3}$ Catalysts. ChemCatChem 2019, 11 , 3903-3912. [CrossRef]

163. Feng, S.; Zhao, B.; Liang, Y.; Liu, L.; Dong, J. Improving Selectivity to 1,3-Propanediol for Glycerol Hydrogenolysis Using W- and Al-Incorporated SBA-15 as Support for Pt Nanoparticles. Ind. Eng. Chem. Res. 2019, 58, 2661-2671. [CrossRef]

164. Zhou, W.; Luo, J.; Wang, Y.; Liu, J.; Zhao, Y.; Wang, S.; Ma, X. WOx domain size, acid properties and mechanistic aspects of glycerol hydrogenolysis over $\mathrm{Pt} / \mathrm{WO}_{\mathrm{x}} / \mathrm{ZrO}_{2}$. Appl. Catal. B Environ. 2019, 242, 410-421. [CrossRef]

165. Liu, L.; Asano, T.; Nakagawa, Y.; Tamura, M.; Okumura, K.; Tomishige, K. Selective Hydrogenolysis of Glycerol to 1,3-Propanediol over Rhenium-Oxide-Modified Iridium Nanoparticles Coating Rutile Titania Support. ACS Catal. 2019, 9, 10913-10930. [CrossRef]

166. Modvig, A.; Kumpidet, C.; Riisager, A.; Albert, J. Ru-Doped Wells-Dawson Polyoxometalate as Efficient Catalyst for Glycerol Hydrogenolysis to Propanediols. Materials 2019, 12, 2175. [CrossRef] [PubMed]

167. Chaminand, J.; Djakovitch, L.; Gallezot, P.; Marion, P.; Pinel, C. Glycerol hydrogenolysis on heterogeneous catalysts. Green Chem. 2004, 6, 359-361. [CrossRef]

168. Fan, Y.; Cheng, S.; Wang, H.; Ye, D.; Xie, S.; Pei, Y.; Hu, H.; Hua, W.; Li, Z.H.; Qiao, M.-H.; et al. Nanoparticulate Pt on mesoporous SBA-15 doped with extremely low amount of $\mathrm{W}$ as a highly selective catalyst for glycerol hydrogenolysis to 1,3-propanediol. Green Chem. 2017, 19, 2174-2183. [CrossRef]

169. Zhou, W.; Guan, Y.; Zhou, Q.; Xie, H.; Yu, X.; Xia, T. Preparation Method of Platinum-Tungsten-Zirconia Catalyst and Its Application in Hydrogenation of Glycerol to Produce 1,3-Propanediol. China Patent CN111389397A, 19 February 2020. 
170. Zhang, C.; Wu, Y.; Zheng, R.; Jin, C.; Sun, X.; Hou, C.; Xia, G.; Li, M. Glycerol Hydrogenolysis Catalyst, Its Preparation Method and Application, and Glycerol Hydrogenolysis Method with It to Produce 1,3-Propanediol. China Patent CN111036208A, 21 April 2020.

171. Wolski, L. Factors affecting the activity and selectivity of niobia-based gold catalysts in liquid phase glycerol oxidation. Catal. Today 2020, 354, 36-43. [CrossRef]

172. Wu, S.T.; She, Q.M.; Tesser, R.; Di Serio, M.; Zhou, C.H. Catalytic glycerol dehydration-oxidation to acrylic acid. Catal. Rev. 2020, 1-43. [CrossRef]

173. Babaei, Z.; Chermahini, A.N.; Dinari, M. Glycerol adsorption and mechanism of dehydration to acrolein over TiO2 surface: A density functional theory study. J. Colloid Interface Sci. 2020, 563, 1-7. [CrossRef]

174. Lewicka, L.; Kalisz, D.; Migdal, A.; Plesnar, M.; Kedziora, A.; Dabrowski, Z. Process for Producing Acrylic Acid via Oxidation of Acrolein. Poland Patent PL227246B1, 2017.

175. Dubois, J.-L.; Patience, G. Process for Preparation of Acrylic Acid from Aqueous Glycerol Solution. Patent Number WO2008087315A2, 24 July 2008.

176. Xu, W.; Yang, B.; Wang, W.; Yao, Q. Method for Synthesizing Acrylic Acid from Glycerol. China Patent CN109305908A, 2019.

177. Belliere-Baca, V.; Loridant, S.; Millet, J.-M.; Lauriol-Garbey, P. Method for Preparing Acrolein from Glycerol or Glycerine. Patent Number WO2010076510A2, 8 July 2010.

178. Liu, R.; Wang, T.; Wei, F.; Jin, Y. Highly Efficient Production of Acrylic Acid by Sequential Dehydration and Oxidation of Glycerol. Ind. Eng. Chem. Res. 2014, 53, 8667-8674. [CrossRef]

179. Prati, L.; Rossi, M. Gold on Carbon as a New Catalyst for Selective Liquid Phase Oxidation of Diols. J. Catal. 1998, 176, 552-560. [CrossRef]

180. Mallat, T.; Baiker, A. Oxidation of Alcohols with Molecular Oxygen on Solid Catalysts. Chem. Rev. 2004, 104, 3037-3058. [CrossRef]

181. Somorjai, G.A.; Zhou, B. Nanotechnology in Catalysis. In Nanostructure Science and Technology; Zhou, B., Han, S., Raja, R., Somorjai, G.A., Eds.; Springer: New York, NY, USA, 2007; Volume 3, ISBN 978-0-387-34687-8.

182. Kimura, H.; Tsuto, K.; Wakisaka, T.; Kazumi, Y.; Inaya, Y. Selective oxidation of glycerol on a platinum-bismuth catalyst. Appl. Catal. A Gen. 1993, 96, 217-228. [CrossRef]

183. Prati, L.; Spontoni, P.; Gaiassi, A. From Renewable to Fine Chemicals Through Selective Oxidation: The Case of Glycerol. Top. Catal. 2009, 52, 288-296. [CrossRef]

184. Ribeiro, L.S.; Rodrigues, E.G.; Delgado, J.J.; Chen, X.; Pereira, M.F.R.; Órfão, J.J.M. Pd, Pt, and Pt-Cu Catalysts Supported on Carbon Nanotube (CNT) for the Selective Oxidation of Glycerol in Alkaline and Base-Free Conditions. Ind. Eng. Chem. Res. 2016, 55, 8548-8556. [CrossRef]

185. Evans, C.D.; Douthwaite, M.; Carter, J.H.; Pattisson, S.; Kondrat, S.A.; Bethell, D.; Knight, D.W.; Taylor, S.H.; Hutchings, G.J. Enhancing the understanding of the glycerol to lactic acid reaction mechanism over AuPt/TiO2 under alkaline conditions. J. Chem. Phys. 2020, 152, 134705. [CrossRef] [PubMed]

186. Purushothaman, R.K.P.; Van Haveren, J.; Van Es, D.; Melián-Cabrera, I.; Meeldijk, J.; Heeres, H.J. An efficient one pot conversion of glycerol to lactic acid using bimetallic gold-platinum catalysts on a nanocrystalline $\mathrm{CeO}_{2}$ support. Appl. Catal. B Environ. 2014, 147, 92-100. [CrossRef]

187. He, Z.; Ning, X.; Yang, G.; Wang, H.; Cao, Y.; Peng, F.; Yu, H. Selective oxidation of glycerol over supported noble metal catalysts. Catal. Today 2020. [CrossRef]

188. Zhang, X.; Yang, P.; Liu, Y.; Pan, J.; Li, D.; Wang, B.; Feng, J. Support morphology effect on the selective oxidation of glycerol over AuPt/ $\mathrm{CeO}_{2}$ catalysts. J. Catal. 2020, 385, 146-159. [CrossRef]

189. Palacio, R.; Álvaro, A.; Blach, D.; Torres, S.; Hernández, D.; López, D.; Martinez, F. Influence of the Acid Properties of the Support on Au-Based Catalysts for Glycerol Oxidation in Aqueous Medium. ChemistrySelect 2020, 5, 7789-7796. [CrossRef]

190. Tao, M.; Li, Y.; Li, Y.; Zhang, X.; Geletii, Y.V.; Wang, X.; Hill, C.L. Heterogenization of polyoxometalates as solid catalysts in aerobic oxidation of glycerol. Catal. Sci. Technol. 2020, 10, 3771-3781. [CrossRef]

191. Choi, Y.-B.; Nunotani, N.; Imanaka, N. Glyceraldehyde production from glycerol over $\mathrm{Pt} / \mathrm{CeO}_{2}-\mathrm{ZrO}_{2}-\mathrm{Fe}_{2} \mathrm{O}_{3} / \mathrm{SBA}-16$ catalysts around room temperature in open air system. Mater. Lett. 2020, 278, 128392. [CrossRef] 
192. Meng, Y.; Wang, H.; Dai, Y.; Zheng, J.; Yu, H.; Zhou, C.; Yang, Y. Modulating the electronic property of Pt nanocatalyst on rGO by iron oxides for aerobic oxidation of glycerol. Catal. Commun. 2020, 144, 106073. [CrossRef]

193. Pakrieva, E.; Kolobova, E.; German, D.; Stucchi, M.; Villa, A.; Prati, L.; Carabineiro, S.; Bogdanchikova, N.; Corberán, V.C.; Pestryakov, A. Glycerol Oxidation over Supported Gold Catalysts: The Combined Effect of $\mathrm{Au}$ Particle Size and Basicity of Support. Processes 2020, 8, 1016. [CrossRef]

194. Liu, M.; Yan, W.; Wu, J.; Wang, S.; Xia, Q.; Fang, T.; Jin, X. Electronically Coupled PtCo/MgAl Hydrotalcite Catalysts Display Tunable Selectivity Toward Glyceric Acid and Lactic Acid for Glycerol Conversion. Catal. Lett. 2020, 150, 2590-2598. [CrossRef]

195. Sever, B.; Yildiz, M. Conversion of glycerol to lactic acid over Au/bentonite catalysts in alkaline solution. React. Kinet. Mech. Catal. 2020, 130, 863-874. [CrossRef]

196. Detoni, C.; Da Silva, A.R.P.; Souza, M.M.V.M. Effect of Pt/HZSM-5 dealumination by high temperature reduction on glycerol oxidation. J. Porous Mater. 2020, 27, 707-717. [CrossRef]

197. Mitran, G.; Neațu, F.; Neațu, S.; Trandafir, M.M.; Florea, M. VAlPOs as Efficient Catalysts for Glycerol Conversion to Methanol. Catalysts 2020, 10, 728. [CrossRef]

198. Yan, H.; Yao, S.; Yin, B.; Liang, W.; Jin, X.; Feng, X.; Liu, Y.; Chen, X.; Yang, C. Synergistic effects of bimetallic $\mathrm{PtRu} / \mathrm{MCM}-41$ nanocatalysts for glycerol oxidation in base-free medium: Structure and electronic coupling dependent activity. Appl. Catal. B Environ. 2019, 259, 118070. [CrossRef]

199. Cherni, D.; Moussa, N.; Nsib, M.F.; Evangelisti, C.; Prati, L.; Villa, A. Base-free glycerol oxidation over N-TiO2 supported Au-Pt catalysts. React. Kinet. Mech. Catal. 2019, 128, 979-990. [CrossRef]

200. Oliveira, H.S.; Oliveira, L.C.A.; Chagas, P.; Sangiorge, D.L.; Figueiredo, M.P.; Siqueira, K.P.F.; Hensen, E.J.; Portilho, M.F. A bifunctional catalyst based on $\mathrm{Nb}$ and $\mathrm{V}$ oxides over alumina: Oxidative cleavage of crude glycerol to green formic acid. New J. Chem. 2020, 44, 8538-8544. [CrossRef]

201. Douthwaite, M.; Powell, N.; Taylor, A.; Ford, G.; López, J.M.; Solsona, B.; Yang, N.; Sanahuja-Parejo, O.; He, Q.; Morgan, D.J.; et al. Glycerol Selective Oxidation to Lactic Acid over AuPt Nanoparticles; Enhancing Reaction Selectivity and Understanding by Support Modification. ChemCatChem 2020, 12, 3097-3107. [CrossRef]

202. Coutanceau, C.; Baranton, S.; Kouamé, R.S.B. Selective Electrooxidation of Glycerol Into Value-Added Chemicals: A Short Overview. Front. Chem. 2019, 7, 100. [CrossRef] [PubMed]

203. Klaas, L.; Modibedi, M.; Mathe, M.; Su, H.; Khotseng, L. Electrochemical Studies of Pd-Based Anode Catalysts in Alkaline Medium for Direct Glycerol Fuel Cells. Catalysts 2020, 10, 968. [CrossRef]

204. Falase, A.; Garcia, K.; Lau, C.; Atanassov, P. Electrochemical and in situ IR characterization of PtRu catalysts for complete oxidation of ethylene glycol and glycerol. Electrochem. Commun. 2011, 13, 1488-1491. [CrossRef]

205. Kim, Y.; Kim, H.W.; Lee, S.; Han, J.; Lee, D.; Kim, J.-R.; Kim, T.-W.; Kim, C.-U.; Jeong, S.-Y.; Chae, H.-J.; et al. The Role of Ruthenium on Carbon-Supported PtRu Catalysts for Electrocatalytic Glycerol Oxidation under Acidic Conditions. Chem CatChem 2017, 9, 1683-1690. [CrossRef]

206. Alaba, P.A.; Lee, C.S.; Abnisa, F.; Aroua, M.K.; Cognet, P.; Pérès, Y.; Daud, W.M.A.W. A review of recent progress on electrocatalysts toward efficient glycerol electrooxidation. Rev. Chem. Eng. 2020. [CrossRef]

207. Ji, Y. Recent Development of Heterogeneous Catalysis in the Transesterification of Glycerol to Glycerol Carbonate. Catalysts 2019, 9, 581. [CrossRef]

208. Leão, R.A.C.; De Souza, R.O.M.A.; Nogueira, D.O.; Silva, G.M.A.; Silva, M.V.M.; Gutarra, M.L.E.; Miranda, L.S.M.; De Castro, A.M.; Itabaiana, I.; De Souza, R.O.M.A. Consecutive lipase immobilization and glycerol carbonate production under continuous-flow conditions. Catal. Sci. Technol. 2016, 6, 4743-4748. [CrossRef]

209. Varma, R.S.; Len, C. Glycerol valorization under continuous flow conditions-recent advances. Curr. Opin. Green Sustain. Chem. 2019, 15, 83-90. [CrossRef]

210. Corporation, H. JEFFSOL Alkylene Carbonates; JEFFSOL: The Woodlands, TX, USA, 2001.

211. Saeidabad, N.G.; Noh, Y.S.; Eslami, A.A.; Song, H.T.; Kim, H.D.; Fazeli, A.; Moon, D.J. A Review on Catalysts Development for Steam Reforming of Biodiesel Derived Glycerol; Promoters and Supports. Catalysts 2020, 10, 910. [CrossRef]

212. Bartoli, M.; Zhu, C.; Chae, M.; Bressler, D.C. Value-Added Products from Urea Glycerolysis Using a Heterogeneous Biosolids-Based Catalyst. Catalysts 2018, 8, 373. [CrossRef] 
213. Manikandan, M.; Sangeetha, P. Optimizing the Surface Properties of MgO Nanoparticles Towards the Transesterification of Glycerol to Glycerol Carbonate. ChemistrySelect 2019, 4, 6672-6678. [CrossRef]

214. De Caro, P.; Bandres, M.; Urrutigoïty, M.; Cecutti, C.; Thiebaud-Roux, S. Recent Progress in Synthesis of Glycerol Carbonate and Evaluation of Its Plasticizing Properties. Front. Chem. 2019, 7, 308. [CrossRef]

215. Das, B.; Mohanty, K. A green and facile production of catalysts from waste red mud for the one-pot synthesis of glycerol carbonate from glycerol. J. Environ. Chem. Eng. 2019, 7, 102888. [CrossRef]

216. Wang, S.; Wang, J.; Okoye, P.U.; Chen, S.; Li, X.; Duan, L.; Zhou, H.; Li, S.; Tang, T.; Zhang, L.; et al. Application of corncob residue-derived catalyst in the transesterification of glycerol with dimethyl carbonate to synthesize glycerol carbonate. BioResources 2019, 15, 142-158. [CrossRef]

217. Chotchuang, A.; Kunsuk, P.; Phanpitakkul, A.; Chanklang, S.; Chareonpanich, M.; Seubsai, A. Production of glycerol carbonate from glycerol over modified sodium-aluminate-doped calcium oxide catalysts. Catal. Today 2020. [CrossRef]

218. Rittiron, P.; Niamnuy, C.; Donphai, W.; Chareonpanich, M.; Seubsai, A. Production of Glycerol Carbonate from Glycerol over Templated-Sodium-Aluminate Catalysts Prepared Using a Spray-Drying Method. ACS Omega 2019, 4, 9001-9009. [CrossRef] [PubMed]

219. Phadtare, D.; Kondawar, S.; Athawale, A.; Rode, C.V. Crystalline LaCoO3 perovskite as a novel catalyst for glycerol transesterification. Mol. Catal. 2019, 475, 110496. [CrossRef]

220. Chaves, D.M.; Da Silva, M.J. A selective synthesis of glycerol carbonate from glycerol and urea over $\mathrm{Sn}(\mathrm{OH}) 2$ : A solid and recyclable in situ generated catalyst. New J. Chem. 2019, 43, 3698-3706. [CrossRef]

221. Arora, S.; Gosu, V.; Kumar, U.K.A.; Subbaramaiah, V. A Facile Approach to Develop Rice Husk Derived Green Catalyst for One-pot Synthesis of Glycerol Carbonate from Glycerol. Int. J. Chem. React. Eng. 2020, 18, 20190078. [CrossRef]

222. Mallesham, B.; Rangaswamy, A.; Rao, B.G.; Rao, T.V.; Reddy, B.M. Solvent-Free Production of Glycerol Carbonate from Bioglycerol with Urea Over Nanostructured Promoted $\mathrm{SnO}_{2}$ Catalysts. Catal. Lett. 2020, 1-16. [CrossRef]

223. Liu, J.; Li, Y.; Zhang, J.; He, D. Glycerol carbonylation with $\mathrm{CO}_{2}$ to glycerol carbonate over $\mathrm{CeO}_{2}$ catalyst and the influence of $\mathrm{CeO}_{2}$ preparation methods and reaction parameters. Appl. Catal. A Gen. 2016, 513, 9-18. [CrossRef]

224. Liu, J.; Li, Y.; Liu, H.; He, D. Photo-thermal synergistically catalytic conversion of glycerol and carbon dioxide to glycerol carbonate over Au/ZnWO4-ZnO catalysts. Appl. Catal. B Environ. 2019, 244, 836-843. [CrossRef]

225. García, H.; García, J.I.; Fraile, J.M.; Mayoral, J.A. Solketal: Green and catalytic synthesis and its classification as a solvent: 2,2-dimethyl-4-hidroxymethyl-1,3-dioxolane, an interesting green solvent produced through heterogeneous catalysis. Chim. Oggi Chem. Today 2008, 26, 10-12.

226. Li, L.; Korányi, T.I.; Sels, B.F.; Pescarmona, P.P. Highly-efficient conversion of glycerol to solketal over heterogeneous Lewis acid catalysts. Green Chem. 2012, 14, 1611-1619. [CrossRef]

227. Nanda, M.R.; Zhang, Y.; Yuan, Z.; Qin, W.; Ghaziaskar, H.S.; Xu, C. Catalytic conversion of glycerol for sustainable production of solketal as a fuel additive: A review. Renew. Sustain. Energy Rev. 2016, 56, 1022-1031. [CrossRef]

228. Talebian-Kiakalaieh, A.; Amin, N.A.S.; Najaafi, N.; Tarighi, S. A Review on the Catalytic Acetalization of Bio-renewable Glycerol to Fuel Additives. Front. Chem. 2018, 6, 573. [CrossRef]

229. Fatimah, I.; Sahroni, I.; Fadillaha, G.; Musawwa, M.M.; Mahlia, T.M.I.; Muraza, O. Glycerol to Solketal for Fuel Additive: Recent Progress in Heterogeneous Catalysts. Energies 2019, 12, 2872. [CrossRef]

230. Deutsch, J.; Martin, A.; Lieske, H. Investigations on heterogeneously catalysed condensations of glycerol to cyclic acetals. J. Catal. 2007, 245, 428-435. [CrossRef]

231. Nanda, M.R.; Yuan, Z.; Qin, W.; Ghaziaskar, H.S.; Poirier, M.-A.; Xu, C. A new continuous-flow process for catalytic conversion of glycerol to oxygenated fuel additive: Catalyst screening. Appl. Energy 2014, 123, 75-81. [CrossRef]

232. Chen, L.; Nohair, B.; Zhao, D.; Kaliaguine, S. Glycerol acetalization with formaldehyde using heteropolyacid salts supported on mesostructured silica. Appl. Catal. A Gen. 2018, 549, 207-215. [CrossRef]

233. Fernández, P.; Fraile, J.M.; Garcia-Bordeje, E.; Pires, E.; Bordejé, G. Sulfonated Hydrothermal Carbons from Cellulose and Glucose as Catalysts for Glycerol Ketalization. Catalysts 2019, 9, 804. [CrossRef]

234. Kowalska-Kus, J.; Held, A.; Frankowski, M.; Nowinska, K. Solketal formation from glycerol and acetone over hierarchical zeolites of different structure as catalysts. J. Mol. Catal. A Chem. 2017, 426, 205-212. [CrossRef] 
235. Da Silva, M.J.; Teixeira, M.G.; Chaves, D.M.; Siqueira, L. An efficient process to synthesize solketal from glycerol over tin (II) silicotungstate catalyst. Fuel 2020, 281, 118724. [CrossRef]

236. Shimura, K.; Yoshida, H. Heterogeneous photocatalytic hydrogen production from water and biomass derivatives. Energy Environ. Sci. 2011, 4, 2467-2481. [CrossRef]

237. Clarizia, L.; Spasiano, D.; Di Somma, I.; Marotta, R.; Andreozzi, R.; Dionysiou, D.D. Copper modified-TiO2 catalysts for hydrogen generation through photoreforming of organics. A short review. Int. J. Hydrogen Energy 2014, 39, 16812-16831. [CrossRef]

238. López-Tenllado, F.; Hidalgo-Carrillo, J.; Montes, V.; Marinas, A.; Urbano, F.; Marinas, J.; Ilieva, L.; Tabakova, T.; Reid, F. A comparative study of hydrogen photocatalytic production from glycerol and propan-2-ol on $\mathrm{M} / \mathrm{TiO}_{2}$ systems (M=Au, Pt, Pd). Catal. Today 2017, 280, 58-64. [CrossRef]

239. Deas, R.; Pearce, S.; Goss, K.; Wang, Q.; Chen, W.-T.; Waterhouse, G.I.N. Hierarchical Au/TiO 2 nanoflower photocatalysts with outstanding performance for alcohol photoreforming under UV irradiation. Appl. Catal. A Gen. 2020, 602, 117706. [CrossRef]

240. Stelmachowski, M.; Marchwicka, M.; Grabowska-Musiał, E.; Diak, M.; Zaleska, A. The Photocatalytic Conversion of (Biodiesel Derived) Glycerol to Hydrogen - A Short Review and Preliminary Experimental Results Part 2: Photocatalytic Conversion of Glycerol to Hydrogen in Batch and Semi-batch Laboratory Reactors. J. Adv. Oxid. Technol. 2014, 17, 179-186. [CrossRef]

241. You, B.; Han, G.; Sun, Y. Electrocatalytic and photocatalytic hydrogen evolution integrated with organic oxidation. Chem. Commun. 2018, 54, 5943-5955. [CrossRef]

242. Kawai, T.; Sakata, T.; Kawai, T.S.T. Hydrogen evolution from water using solid carbon and light energy. Nat. Cell Biol. 1979, 282, 283-284. [CrossRef]

243. Ma, D.; Zhai, S.; Wang, Y.; Liu, A.; Chen, C. TiO2 Photocatalysis for Transfer Hydrogenation. Molecules 2019, 24, 330. [CrossRef]

244. Al-Azri, Z.H.; Chen, W.-T.; Chan, A.; Jovic, V.; Ina, T.; Idriss, H.; Waterhouse, G.I. The roles of metal co-catalysts and reaction media in photocatalytic hydrogen production: Performance evaluation of $\mathrm{M} / \mathrm{TiO}_{2}$ photocatalysts ( $\mathrm{M}=\mathrm{Pd}, \mathrm{Pt}, \mathrm{Au})$ in different alcohol-water mixtures. J. Catal. 2015, 329, 355-367. [CrossRef]

245. Slamet, R.; Gunlazuardi, J.; Dewi, E.L. Enhanced photocatalytic activity of Pt deposited on titania nanotube arrays for the hydrogen production with glycerol as a sacrificial agent. Int. J. Hydrogen Energy 2017, 42, 24014-24025. [CrossRef]

246. Chen, W.-T.; Dosado, A.G.; Chan, A.; Sun-Waterhouse, D.; Waterhouse, G.I. Highly reactive anatase nanorod photocatalysts synthesized by calcination of hydrogen titanate nanotubes: Effect of calcination conditions on photocatalytic performance for aqueous dye degradation and $\mathrm{H}_{2}$ production in alcohol-water mixtures. Appl. Catal. A Gen. 2018, 565, 98-118. [CrossRef]

247. O'Rourke, C.; Wells, N.; Mills, A. Photodeposition of metals from inks and their application in photocatalysis. Catal. Today 2019, 335, 91-100. [CrossRef]

248. Sadanandam, G.; Lalitha, K.; Kumari, V.D.; Shankar, M.V.; Subrahmanyam, M. Cobalt doped TiÖ2: A stable and efficient photocatalyst for continuous hydrogen production from glycerol: Water mixtures under solar light irradiation. Int. J. Hydrogen Energy 2013, 38, 9655-9664. [CrossRef]

249. Hidalgo-Carrillo, J.; Martín-Gómez, J.; Morales, J.; Espejo, J.C.; Urbano, F.J.; Marinas, A. Hydrogen Photo-Production from Glycerol Using Nickel-Doped $\mathrm{TiO}_{2}$ Catalysts: Effect of Catalyst Pre-Treatment. Energies 2019, 12, 3351. [CrossRef]

250. Lalitha, K.; Sadanandam, G.; Kumari, V.D.; Subrahmanyam, M.; Sreedhar, B.; Hebalkar, N.Y. Highly Stabilized and Finely Dispersed $\mathrm{Cu}_{2} \mathrm{O} / \mathrm{TiO}_{2}$ : A Promising Visible Sensitive Photocatalyst for Continuous Production of Hydrogen from Glycerol: Water Mixtures. J. Phys. Chem. C 2010, 114, 22181-22189. [CrossRef]

251. Kumar, D.P.; Reddy, N.L.; Kumari, M.M.; Srinivas, B.; Kumari, V.D.; Sreedhar, B.; Roddatis, V.V.; Bondarchuk, O.; Karthik, M.; Neppolian, B.; et al. $\mathrm{Cu}_{2} \mathrm{O}$-sensitized $\mathrm{TiO}_{2}$ nanorods with nanocavities for highly efficient photocatalytic hydrogen production under solar irradiation. Sol. Energy Mater. Sol. Cells 2015, 136, 157-166. [CrossRef]

252. Chen, W.-T.; Chan, A.; Sun-Waterhouse, D.; Llorca, J.; Idriss, H.; Waterhouse, G.I. Performance comparison of $\mathrm{Ni} / \mathrm{TiO}_{2}$ and $\mathrm{Au} / \mathrm{TiO}_{2}$ photocatalysts for $\mathrm{H}_{2}$ production in different alcohol-water mixtures. J. Catal. 2018, 367, 27-42. [CrossRef] 
253. Wang, Q.; Zhang, D.; Chen, Y.; Fu, W.-F.; Lv, X.-J. Single-Atom Catalysts for Photocatalytic Reactions. ACS Sustain. Chem. Eng. 2019, 7, 6430-6443. [CrossRef]

254. Pan, H.; Steiniger, A.; Heagy, M.D.; Chowdhury, S. Efficient production of formic acid by simultaneous photoreduction of bicarbonate and oxidation of glycerol on gold- $\mathrm{TiO}_{2}$ composite under solar light. J. $\mathrm{CO}_{2}$ Util. 2017, 22, 117-123. [CrossRef]

255. Charisiou, N.D.; Siakavelas, G.I.; Papageridis, K.; Motta, D.; Dimitratos, N.; Jaoude, M.A.; Polychronopoulou, K.; Goula, M.A. The Effect of Noble Metal (M: Ir, Pt, Pd) on M/Ce $\mathrm{O}_{3}-\gamma-\mathrm{Al}_{2} \mathrm{O}_{3}$ Catalysts for Hydrogen Production via the Steam Reforming of Glycerol. Catalysts 2020, 10, 790. [CrossRef]

256. Bac, S.; Keskin, S.; Avci, A.K. Recent advances in sustainable syngas production by catalytic $\mathrm{CO}_{2}$ reforming of ethanol and glycerol. Sustain. Energy Fuels 2020, 4, 1029-1047. [CrossRef]

257. Vaidya, P.D.; Lopez-Sanchez, J.A. Review of Hydrogen Production by Catalytic Aqueous-Phase Reforming. ChemistrySelect 2017, 2, 6563-6576. [CrossRef]

258. Jin, W.; Pastor-Pérez, L.; Shen, D.; Sepulveda-Escribano, A.; Gu, S.; Reina, T.R. Catalytic Upgrading of Biomass Model Compounds: Novel Approaches and Lessons Learnt from Traditional Hydrodeoxygenation-A Review. Chem CatChem 2019, 11, 924-960. [CrossRef]

259. Jin, X.; Yin, B.; Xia, Q.; Fang, T.; Shen, J.; Kuang, L.; Yang, C. Catalytic Transfer Hydrogenation of Biomass-Derived Substrates to Value-Added Chemicals on Dual-Function Catalysts: Opportunities and Challenges. ChemSusChem 2018, 12, 71-92. [CrossRef]

260. Toledano, A.; Serrano, L.; Labidi, J.; Pineda, A.; Balu, A.M.; Luque, R. Heterogeneously Catalysed Mild Hydrogenolytic Depolymerisation of Lignin Under Microwave Irradiation with Hydrogen-Donating Solvents. ChemCatChem 2012, 5, 977-985. [CrossRef]

261. Crotti, C.; Farnetti, E.; Licen, S.; Barbieri, P.; Pitacco, G. Iridium-catalyzed N-alkylation of diamines with glycerol. J. Mol. Catal. A Chem. 2014, 382, 64-70. [CrossRef]

262. Cui, S.; Borgemenke, J.; Liu, Z.; Keener, H.M.; Li, Y. Innovative sustainable conversion from CO2 and biodiesel-based crude glycerol waste to bio-based polycarbonates. J. $\mathrm{CO}_{2}$ Util. 2019, 34, 198-206. [CrossRef]

263. Estevez, R.; Aguado-Deblas, L.; Montes, V.; Caballero, A.; Bautista, F. Sulfonated carbons from olive stones as catalysts in the microwave-assisted etherification of glycerol with tert-butyl alcohol. Mol. Catal. 2020, 488, 110921. [CrossRef]

264. Calmanti, R.; Amadio, E.; Perosa, A.; Selva, M. Reaction of Glycerol with Trimethyl Orthoformate: Towards the Synthesis of New Glycerol Derivatives. Catalysts 2019, 9, 534. [CrossRef]

265. Zhang, Y.; Ma, T.; Zhao, J. Study on the conversion of glycerol to nitriles over a $\mathrm{Fe}_{19.2} \mathrm{~K}_{0.2} / \gamma-\mathrm{Al}_{2} \mathrm{O}_{3}$ catalyst. J. Catal. 2014, 313, 92-103. [CrossRef]

266. Du, F.; Jin, X.; Yan, W.; Zhao, M.; Thapa, P.S.; Chaudhari, R.V. Catalytic $\mathrm{H}_{2}$ auto transfer amination of polyols to alkyl amines in one pot using supported Ru catalysts. Catal. Today 2018, 302, 227-232. [CrossRef]

267. Pandya, R.; Mane, R.B.; Rode, C.V. Cascade dehydrative amination of glycerol to oxazoline. Catal. Sci. Technol. 2018, 8, 2954-2965. [CrossRef]

268. Wormann, M.; Maier, M.E. Synthesis of allyl alcohol as a method to valorise glycerol from the biodiesel production. RSC Adv. 2019, 9, 15314-15317. [CrossRef]

269. L'Hostis, C.; Fredon, E.; Thévenon, M.-F.; Santiago-Medina, F.-J.; Gérardin, P. Beech wood treated with polyglycerol succinate: A new effective method for its protection and stabilization. Holzforschung 2020, 74, 351-361. [CrossRef]

270. Zamboulis, A.; Nakiou, E.A.; Christodoulou, E.; Bikiaris, D.N.; Kontonasaki, E.; Liverani, L.; Boccaccini, A.R. Polyglycerol Hyperbranched Polyesters: Synthesis, Properties and Pharmaceutical and Biomedical Applications. Int. J. Mol. Sci. 2019, 20, 6210. [CrossRef] [PubMed]

271. Barros, F.J.S.; Cecilia, J.A.; Moreno-Tost, R.; De Oliveira, M.F.; Soto, J.; Luna, F.M.T.; Vieira, R.S. Glycerol Oligomerization Using Low Cost Dolomite Catalyst. Waste Biomass Valoriz. 2018, 11, 1499-1512. [CrossRef]

272. Sotto, N.; Cazorla, C.; Villette, C.; Billamboz, M.; Len, C. Toward the Sustainable Synthesis of Biosourced Divinylglycol from Glycerol. ACS Sustain. Chem. Eng. 2016, 4, 6996-7003. [CrossRef]

273. Yu, H.; Xue, Z.; Lan, X.; Liu, Q.; Shi, R.; Mu, T. Highly efficient dissolution of xylan in ionic liquid-based deep eutectic solvents. Cellulose 2020, 27, 6175-6188. [CrossRef]

274. Saputra, R.; Walvekar, R.; Khalid, M.; Mubarak, N.M. Synthesis and thermophysical properties of ethylammonium chloride-glycerol- $\mathrm{ZnCl}_{2}$ ternary deep eutectic solvent. J. Mol. Liq. 2020, 310, 113232. [CrossRef] 
275. Hoang, T.Q.; Zhu, X.; Danuthai, T.; Lobban, L.L.; Resasco, D.E.; Mallinson, R.G. Conversion of Glycerol to Alkyl-aromatics over Zeolites. Energy Fuels 2010, 24, 3804-3809. [CrossRef]

276. Xu, W.; Gao, L.; Xiao, G. Effects of Additives and Metals on Crystallization of Nano-Sized HZSM-5 Zeolite for Glycerol Aromatization. Catalysts 2019, 9, 899. [CrossRef]

277. Zhang, J.; Wang, L.; Ji, Y.; Chen, F.; Xiao, F.-S. Mesoporous zeolites for biofuel upgrading and glycerol conversion. Front. Chem. Sci. Eng. 2017, 12, 132-144. [CrossRef]

278. Possato, L.G.; Diniz, R.N.; Garetto, T.; Pulcinelli, S.H.; Santilli, C.V.; Martins, L. A comparative study of glycerol dehydration catalyzed by micro/mesoporous MFI zeolites. J. Catal. 2013, 300, 102-112. [CrossRef]

279. Kumar, D.; Anand, N.; Pant, K.K. Glycerol conversion over palladium- and alumina-impregnated KIT-6 for the production of gasoline range hydrocarbons. Clean Technol. Environ. Policy 2017, 20, 751-757. [CrossRef]

280. He, S.; Zuur, K.; Santosa, D.S.; Heeres, A.; Liu, C.; Pidko, E.A.; Heeres, H.J. Catalytic conversion of pure glycerol over an un-modified H-ZSM-5 zeolite to bio-based aromatics. Appl. Catal. B Environ. 2021, 281, 119467. [CrossRef]

281. Ismail, H.; Zaaba, N. The mechanical properties, water resistance and degradation behaviour of silica-filled sago starch/PVA plastic films. J. Elastomers Plast. 2012, 46, 96-109. [CrossRef]

282. Devi, B.L.A.P.; Gangadhar, K.N.; Prasad, P.S.S.; Jagannadh, B.; Prasad, R.B.N. A Glycerol-based Carbon Catalyst for the Preparation of Biodiesel. ChemSusChem 2009, 2, 617-620. [CrossRef]

283. Ribeiro, R.S.; Silva, A.M.; Pinho, M.T.; Figueiredo, J.L.; Faria, J.L.; Gomes, H.T. Development of glycerol-based metal-free carbon materials for environmental catalytic applications. Catal. Today 2015, 240, 61-66. [CrossRef]

284. Cui, Y.; Atkinson, J.D. Tailored activated carbon from glycerol: Role of acid dehydrator on physiochemical characteristics and adsorption performance. J. Mater. Chem. A 2017, 5, 16812-16821. [CrossRef]

285. Estes, C.S.; Gerard, A.Y.; Godward, J.D.; Hayes, S.B.; Liles, S.H.; Shelton, J.L.; Stewart, T.S.; Webster, R.I.; Webster, H.F. Preparation of highly functionalized carbon nanoparticles using a one-step acid dehydration of glycerol. Carbon 2019, 142, 547-557. [CrossRef]

286. Medeiros, M.A.; Ardisson, J.D.; Lago, R.M. Preparation of magnetic mesoporous composites from glycerol and Fe (III) salt. J. Chem. Technol. Biotechnol. 2019, 95, 1038-1045. [CrossRef]

287. Antunes, E.; Jacob, M.V.; Brodie, G.; Schneider, P.A. Microwave pyrolysis of sewage biosolids: Dielectric properties, microwave susceptor role and its impact on biochar properties. J. Anal. Appl. Pyrolysis 2018, 129, 93-100. [CrossRef]

288. Cui, Y.; Atkinson, J.D. Glycerol-derived magnetic mesoporous Fe/C composites for $\mathrm{Cr}(\mathrm{VI})$ removal, prepared via acid-assisted one-pot pyrolysis. Chemosphere 2019, 228, 694-701. [CrossRef]

289. Wu, H.; Li, Z.; Liu, H. Development of carbon adsorbents with high surface acidity and basicity from polyhydric alcohols with phosphoric acid activation for Ni(II) removal. Chemosphere 2018, 206, 115-121. [CrossRef]

290. Gonçalves, M.; Oliveira, C.C.; Boas, I.K.; Soler, F.C.; Pinto, E.D.C.; Lavall, R.L.; Carvalho, W.A. Glycerin waste as sustainable precursor for activated carbon production: Adsorption properties and application in supercapacitors. J. Environ. Chem. Eng. 2019, 7, 103059. [CrossRef]

291. Uchôa, I.M.A.; Neto, A.A.D.; Santos, E.D.S.; De Lima, L.F.; Neto, E.L.D.B. Evaluation of Lubricating Properties of Diesel Based Fuels Micro Emulsified With Glycerin. Mater. Res. 2017, 20, 701-708. [CrossRef]

292. Mikhailenko, P.; Bertron, A.; Boussambe, G.N.M.; Valentin, R.; Mouloungui, Z.; Ringot, E. Recycled bio-sourced glycerol and diglycerol for asphalt release agents (ARA). Road Mater. Pavement Des. 2018, 21, 201-216. [CrossRef]

293. Mishra, V.; Singh, D.; Habal, A. Investigating the condition number approach to select probe liquids for evaluating surface free energy of bitumen. Int. J. Pavement Res. Technol. 2019, 13, 10-19. [CrossRef]

294. Campos, W.E.O.; Nobre, F.X.; Filho, G.N.D.R.; Da Silva, M.A.R.; Da Costa, C.E.F.; Nascimento, L.A.S.D.; Zamian, J.R. High Photocatalytic Activity under Visible Light for a New Morphology of Bi2WO6 Microcrystals. Catalysts 2019, 9, 667. [CrossRef]

295. Ye, L.; Jin, X.; Liu, C.; Ding, C.; Xie, H.; Chu, K.H.; Wong, P.K. Thickness-ultrathin and bismuth-rich strategies for BiOBr to enhance photoreduction of $\mathrm{CO}_{2}$ into solar fuels. Appl. Catal. B Environ. 2016, 187, 281-290. [CrossRef]

296. Kim, M.; Son, W.-S.; Ahn, K.H.; Kim, D.S.; Lee, H.-S.; Lee, Y.-W. Hydrothermal synthesis of metal nanoparticles using glycerol as a reducing agent. J. Supercrit. Fluids 2014, 90, 53-59. [CrossRef] 
297. Lakshmanan, P.; Park, E.D. Preferential CO Oxidation in $\mathrm{H}_{2}$ over $\mathrm{Au} / \mathrm{La}_{2} \mathrm{O}_{3} / \mathrm{Al}_{2} \mathrm{O}_{3}$ Catalysts: The Effect of the Catalyst Reduction Method. Catalysts 2018, 8, 183. [CrossRef]

298. Lakshmanan, P.; Upare, P.P.; Le, N.-T.; Hwang, Y.K.; Hwang, D.W.; Lee, U.-H.; Kim, H.R.; Chang, J.-S. Facile synthesis of $\mathrm{CeO}_{2}$-supported gold nanoparticle catalysts for selective oxidation of glycerol into lactic acid. Appl. Catal. A Gen. 2013, 468, 260-268. [CrossRef]

Publisher's Note: MDPI stays neutral with regard to jurisdictional claims in published maps and institutional affiliations.

(C) 2020 by the authors. Licensee MDPI, Basel, Switzerland. This article is an open access article distributed under the terms and conditions of the Creative Commons Attribution (CC BY) license (http://creativecommons.org/licenses/by/4.0/). 